\title{
AN ASSESSMENT OF THE STATUS OF FUEL CELL/BATTERY VEHICLE POWER SYSTEMS
}

William J.D. Escher and Richard W. FOSter

February 1980

Prepared by:

ESCHER:FOSTER TECHNOLOGY ASSOCIATES, INC.

St. Johns, Michigan 48879

DEPARTMENT OF ENERGY AND FNVIRONMENT

BROOKHAVEN NATIONAL LABORATORY UPTON, NEW YORK 11973 


\section{DISCLAIMER}

This report was prepared as an account of work sponsored by an agency of the United States Government. Neither the United States Government nor any agency Thereof, nor any of their employees, makes any warranty, express or implied, or assumes any legal liability or responsibility for the accuracy, completeness, or usefulness of any information, apparatus, product, or process disclosed, or represents that its use would not infringe privately owned rights. Reference herein to any specific commercial product, process, or service by trade name, trademark, manufacturer, or otherwise does not necessarily constitute or imply its endorsement, recommendation, or favoring by the United States Government or any agency thereof. The views and opinions of authors expressed herein do not necessarily state or reflect those of the United States Government or any agency thereof. 


\section{DISCLAIMER}

Portions of this document may be illegible in electronic image products. Images are produced from the best available original document. 
This book was prepared as an account of work sponsored by an ageney of the United States Governmens.

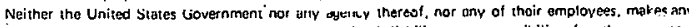
warranty, express or implied, or assumes any legal liability or responsibility for the accuracy.

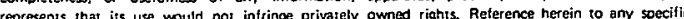

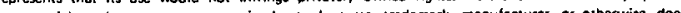

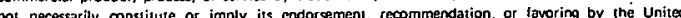
States Government or any agen thereot. The views and opinions of authors expressed herein do not necessarily state or reflecs those of the United States Government or sny agency thereof.
UC-94c,94d

(Energy Storage-Electrochemical; Chemical - TID-4500)

\title{
AN ASSESSMENT OF THE STATUS \\ OF FUEL CELL/BATTERY VEHICLE POWER SYSTEMS
}

\author{
Prepared by \\ William J.D. Escher and Richard W. Foster
}

Contributor

RAYMOND R. TISON

ESCHER:FOSTER TECHNOLOGY ASSOCIATES, INC.

P.O. Box 189

St. Johns, Michigan 48879

February 1980

Under a Cooperative Study

"Energy Storage Systems for Automobile Propulsion".

Conducted by

Lawrence Livermore Laboratory

Livermore, California 94550
Sponsored by

U.S. Department of Energy

Division of Energy Storage Systems

Washington, D.C. 20585

ENERGY STORAGE AND CONVERSION DIVISION

DEPARTMENT OF ENERGY AND ENVIRONMENT

BROOKHAVEN NATIONAL LABORATORY

ASSOCIATED UNIVERSITIES, INC.

UNDER CONTRACT NO. DE-AC02-76CH00016 WITH THE

UNITED STATES DEPARTMENT OF ENERGY 


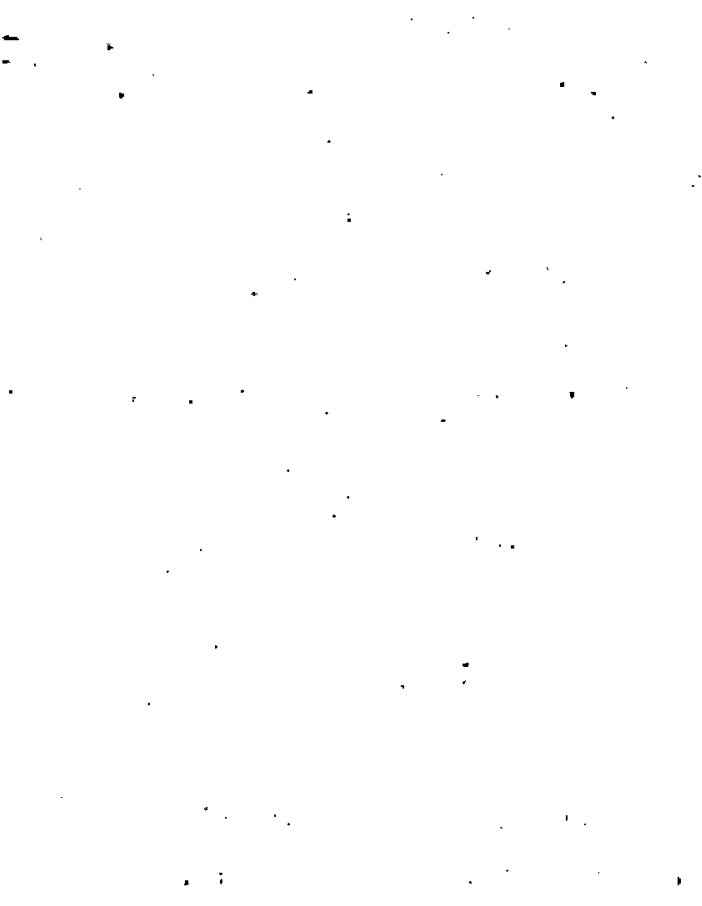

D̃ISCLAIMER

This hook was prepared as an account of work sponsored by an agcncy of the United States Government. Neither the United States Government nor any agenry therenf, nor any of their employees, makes any warranty, express or implied, or assumes any legal liability or, responsibility for the accuracy, completeness, or usefulness of any information, apparatus, product, or prueess disulused, ur represeres that les use wusuld not infringe privately owned rights. Reference herein to any specific commercial producl, prucess, ur service by trade nâmé, trademark, manufacturer, or otherwise, does not necessarily constitute or imply its endorsement, recommendation, or favoring by the United States Government or any agency thereof. The views and opinions of authors expressed herein do not necessarily state or reflect those of the United States Government or any agency thereof.

Printed in the United States of America Available from

National Technical Information Service

U.S. Department of Commerce

5285 Port Royal Road

Springfield, VA 22161

Price: Printed Copy $\$ 7.25$; Microfiche $\$ 3.00$ 
ABSTRACT . ix

GLOSSARY $\quad x$

FOREWORD $\quad x i$

EXECUTIVE SUMMARY. XIii

SECTION 1. INTRODUCTION AND SUMMARY

A. TECHNICAL CONCEPT AND RATIONALE 1

B.. TECHNICAL AND PROGRAM STATUS OF TRANSPCRTATION FUEL CELLS
AND BATTERIES

C. BACKGROUND AND STATUS OF FUEL CELL/BATTERY VEHICLE POWER
SYSTEMS ACTIVITIES

References Cited for Section 1 11

SECTION 2. OBSERVATIONS, CONCLUSIONS, AND RECOMMENDATIONS

A. OBSERVATIONS 13

Status of Transportation Fuel Cell R\&D 13

Benefits of the Fuel Cells/Battery Power System

to Electric Vehicles 13

Present Industry and Government Involvement 13

overseas Involvement $\quad 14$

Alternative Vehicle Applications $\quad 14$

Fuel Cell Relationship to the Electric Vehicle 14

$\begin{array}{ll}\text { Fuel Cell/Battery Vehicle Differences } & 14\end{array}$

Implications of Methanol and Hydrogen Fuels . 15

Coal as a Primary Energy Resource 15

Estimated Costs of Fuels 16

Estimated Costs for Transportation Fuel Cells and
Batteries

B. CONCLUSIONS 16

C. RECOMMENDATIONS 17

$\begin{array}{ll}\text { General Recommendations } & 17\end{array}$ 
TABLE OF CONTENTS, cont.

Page

Specific Recommendations

Feferences Cited in Section 2

SECTION 3. OBJECTIVES AND SCOPE OF ASSESSMENT

A. OBJECTIVES OF THE ASSESSMENT $\quad$. 21

B. SCOPE OF THE ASSESSMENT $\quad 22$

SECTION 4. TASK FINDINGS

A. LITERATURE SEARCH RESULTS 23

Objective o: Task $\quad 23$

Approach $\quad \cdot 23$

$\begin{array}{ll}\text { Presentation of Findings } & 24\end{array}$

The Transportation Fuel Cell vis-a-vis Battery

$\begin{array}{ll}\text { Literature } & 24\end{array}$

Background for Transportation Fuel Cell systems . 25

Hybrid Battery Concept $\quad . \quad . \quad . \quad . \quad 26$

Fuel Cell/Battery Power Systeme $\quad 28$

Current Estimates of Vehicle Fuel Cell Costs . $\quad 30$

Current Estimates of Vehicle Battery Costs 30

Bibliography for Section 4A

B. CURRENT VIEWS AND WORK IN PROGRESS 34

Objective of Task $\quad 34$

Approach $\quad \cdot \quad 34$

Summary of Findings . . . . . 34

Automotive Industry contacts $\quad 34$ 
TABLE OF CONTENTS, Cont.

\begin{tabular}{lr} 
& \multicolumn{1}{c}{ page } \\
Government and the National Laboratories & 35 \\
Discussion of Automotive Industry Contacts & 36 \\
$\begin{array}{l}\text { Discussion of Government and National Laboratory. } \\
\text { Contacts }\end{array}$ & 39
\end{tabular}

References Cited in Section 4B $\quad 41$

C. RD\&D NEEDS AND OPPORTUNITIES $\quad 44$

Objective of the Task $\quad 44$

$\begin{array}{ll}\text { Approach } & 44\end{array}$

Technical and Program Status $\quad 44$

RD\&D Needs and Opportunities 45

D. RELATIONSHIPS: BATTERY (ONLY) AND FUEL CELL/BATTERY
VEHICLE POWER SYSTEMS

Objective of Task $\quad 49$

$\begin{array}{lr}\text { Approach } & 49\end{array}$

General Relationships $\quad 49$

The Issue of Energy Supply

Possible Market Place Interactions 53

References Cited for Section 4D

E. OUTLOOK FOR FUTURE AVAILABILITY OF HYDROGEN AND

METHANOL FROM COAL $\quad 56$

Objective of Task $\quad 56$

$\begin{array}{ll}\text { Approach } & 56\end{array}$

General Findings: Methanol and Hydrogen Industrial
rractice and Prospects fur Cudl Use

Incentives and Special Supply Possibilities $\quad 62$ 
TABLE OF CONTENTS, Cont.

Page

The Coal Supply Issue

Fuel Requirements of Fuel Cell/Battery Vehicles

65

A Special Note: Methanol is. Fuel-Grade Methanol

References Cited for Section $4 \mathrm{E}$

Special Note Regarding Efforts Underway in the Joint Dutch/Belgium Effort by ELENCO (and by siemens AG in Wést Germany)

F. TRELIMINARY COMPARATIVE VEHICLE EIMULATION FINDINCE AND RELATED DISCUSSION

Background

Objective of l'ask

Approach

Vehicle and Fuel Systems Simulated

Findings

References Cited in Section $4 \mathrm{~F}$

APPENDICES

Appendix A. Excerpt From "Fuel Cells for Electric. 82 Vehicles"

Appendix B. Methanol Example Run and Liquid Hydrogen Eisimpic Hun

Appendix C. The Influence of Fuel Cell/Battery Power Systems Costs on Operating Costs

Appendix D. Recent Developmento in Cryogenic Ilydrogen Container Technology for Vehicles 
Figure No.

Fuel Cell/Battery Vehicle Power System Functional Schematic Diagrams

Ragone Plots for Batteries, Fuel Cells, and Various Heat Engines

4-1 Status of the Transportation Battery, Fuel Cell, and Fuel Cell/Batteries Technologies

A Simplified Model of the Stages and Decisions in the Process of Automotive Technology Development and Production

4-3 Suggested Interrelationships Between the Three Design Concepts Assuming the Fuel Cell/Battery Designs Were to be Further Pursued.

4-4 Hydrogen Manufacturing Costs - Midcontinent Location

4-5 Methanol Manufacturing Costs - Midcontinent Location

Coal Development system

IGT Laboratory- and Fuel-Grade Methanol Steam Reforming Results 


\section{LIST OF TABLES}

Table No.

Page

$1-1$

Fuel Cell and Battery Technology Advances

7

1-2 Battery Funding Showing Portion Allocated to EV Batteries

8

4-1 Principal Contacts Made by Assessment Team

1975 U.S. Hydrogen Requirements

$4-3$

Comparison of Fuel Cell/Battery Fuel Requirements with Current II.S. Methanol, IIydrogen, and Coal froduction

4-4 Comparison of Simulations of Various Cases of Hydrogen and Methanol Fueled Fuel Cell/ Battery Vehicle Systems in the Volkswagen "Rabbit" Vehicle Type 
ABSTRACT

An assessment of the status of the integrated fuel cel1/battery power system concept for electric vehicle propulsion, is reported. The fuel cell, operating on hydrogen or methanol (indirectly), acts as a very high capacity "energy battery" for vehicle sustaining operation, while a special "power battery" provides over-capacity transient power on demand, being recharged by the fuel cell, e.g., during cruising.

A focused literature search and a set of industrial and Government contacts were carried out to establish views, outlooks, and general status concerning the concept. It is evident that, although vehicle battery R\&D is being actively pursued, little of today's fuel cell work is directed to transportation usage. Only very limited attention has been, and is being, given to the fuel cell/battery power system concept itself.

However, judging largely from computer-simulated driving cycle results, the concept can provide needed range capabilities and general operating flexibility to electric vehicles. New transportation applications, conventionally viewed as beyond the capability of electric vehicles, may thereby be practical, e.g., rail, trucks.

In view of these potential and important benefits, and the absence of any comprehensive research, development, and demonstration activities which are supportive of the fuel cell/battery system concept, the initiation of an appropriate effort is recommended by the Assessment Team. This general recommendation is supported by applicable findings, observations, and conclusions. 


\section{GLOSSARY}

$\begin{array}{ll}\text { ANL } & \text { Argonne National Laboratory } \\ \text { BNL } & \text { Brookhaven National Laboratory } \\ \text { DOE } & \text { U.S. Department of Energy } \\ \text { DOT } & \text { U.S. Department of Transportation } \\ \text { ERDA } & \text { U.S. Energy Research and Development Administration (now } \\ \text { EV } & \text { Electric Vehicle } \\ \text { IGT } & \text { Institute of Gas Technology } \\ \text { LAEL } & \text { Los Alamos Scientifis Lahoratory, Iniversity of } \\ \text { California } & \text { Lawrence Livermore Laboratory, University of } \\ \text { LLL } & \text { Californid } \\ \text { MERADCOM } & \text { Mobility Equipment Research and Devlopment Command, } \\ \text { U.S. Army, located at Fort Belvoir, Virginia } \\ \text { RD\&D }\end{array}$


FOREWORD

Hydrogen-air fuel cells, coupled with storage batterles, offer a promising option which would permit electric vehicles to out-perform current battery-powered vehicles. The purpose of this report is to assess the status of the fuel cell/battery approach for efficlently ut1lizing our abundant and renewable resources in the transportation sector--particularly for automobiles. This use of fuel, in the form of hydrogen, and derived from water using coal, solar, hydro, wind, and geothermal primary energy resources, is highly desirable because it would reduce our dependence on petroleum-based fuels. Moving off oll dependency is a primary goal of the U.S. Department of Energy (DOE). Specifically, the goal of the Division of Energy Storage Systems (STOR) in the DOE is to assess and develop promising fuel storage systems which conserve petroleum.

Unlike batteries, fuel cells have their supply of fuel stored in a separate container which can be sized for range--just as gasoline tanks are. The fuel cell can indirectly use abundant or renewable resources by reacting hydrogen gas and the oxygen in air to produce electrical energy (and water) for propulsion. Thus hydrogen serves as an energy carrier. As stated, hydrogen can be made from water, via electrolysis, using electrical energy produced from renewable primary energy sources. Alternatively, the hydrogen can be made from coal-derived methanol, which is processed to yleld hydrogen on-board the vehicle.

The potential improvement in vehicle performance over conventional battery vehicles is based on use of the fuel cells for range, and the batteries for power surges. A flywheel system could also be considered for supplying surge power. With this mode of load sharing, each device can be optimized for its role in the propulsion system. During periods of light load, the batteries are recharged by the fuel cells using fuel carried on-board. Furthermore, in comparison with the internal combustion engine (ICE), the fuel cell offers substantial. energy conservation because its overall efficiency is two to three times that of the ICE.

A related study program supported by DOE/STOR, and conducted by the Lawrence Livermore Laboratory (LLL), deals with a comparison of candidate energy storage systems for automobile propulsion. Here, various batteries, 
the fuel cell/battery, flywheels, hydrogen-powered engines, and hybrid systems are considered in computer-modeled automobiles of various sizes and performance capabilities. Results of the study show that the optimistic projections made for the fuel cell/battery system generally compare favorably with those made for alternative systems. The present report assessing status of the fuel cell/battery system was conducted as part of the LLL study activ1ty under its Chemical Energy Storage Panel. The effort was conducted under subcontract to Brookhaven National Laboratory (BNL).

From this assessment report, it is evident that the fuel cell is a potential key to developing our abundant and renewable resources for fueling automobiles--and perhaps for trucks, buses, and trains. An appropriate avenue for initlating work on this new concept exists in Public Law 94-413, "The Electric and Hybrid Vehicle Research, Development and Demonstration Act of 1976," because fuel cells, along with batteries, are within its scope.

Gerald Strickland (BNL), Chairman Chemical Energy Storage Panel LLL Program on Energy Storage Systems for Automobile Propulsion

Frank J. Salzano, Head Eutigy Slulage alld Conversion Division Brookhaven National Laboratory 


\section{AN ASSESSMENT OF THE STATUS OF \\ FUEL CELL/BATTERY VEHICLE POWER SYSTEMS}

\section{EXECUTIVE SUMMARY}

A. MOVING TRANSPORTATION OFF OIL - THE GOAL

Because the transportation sector consumes about $55 \%$ of all petroleum used in the Unfted States, and about half of that is being imported at increasingly higher prices, it is imperative to find ways of reducing our dependence on imported oil. The consequences of the nation's dependency on oil imports to satisfy the demand for petroleum-based fuels and products have been a source of major concern from a political, economic, social and technological perspective. To help offset these concerns, the Department of Energy has assigned a high priority to technology development activities which place emphasis on: (1) identification and implementation of fuel alternatives which would be derived from our coal supply or from renewable resources; and, (2) development of the electric vehicle. The merits of either or both of these strategies can be enhanced by including parallel approaches which will allow additional market penetration and are consistent with the goal of effectively moving transportation off oil. This report provides an assessment on the status of, and a rationale for, a complementary strategy--development of the automotive fuel cell/battery power system.

B. THE COMPREHENSIVE MERITS OF ALTERNATIVE OR COMPLEMENTARY STRATEGIES

The automotive fuel cell offers the promise of embodying the best features of the fuel and electric traction-power alternatives, while overriding their negative features. It is recognized that fuels derived from coal or renewable resources w11l be costly in the near term--especially if utilized in conventional internal combustion engines, which operate at efficiencies as low as $10 \%$ over representative driving cycles. Fuel cell systems can use similar fuels and provide energy conversion efficiencies two to three times that nf internal combustion engines. Electric vehicles, even those utilizing advanced state-of-tlié-art batteries, w 111 depend on off-peak charge rates to approach cost competitiveness; and they presently require long recharge times and have poor performance (range/acceleration), due to low energy and power densities 
of the batteries. Fuel-cell systems can be refueled in times that compare favorably with conventional automotive refueling practice; and they can be effectively integrated with storage batteries to provide performance profiles similar to those of conventional vehicles.

C. THE AUTOMOTIVE FUEL-CELL/BATTERY CONCEPT

The fuel cell has enjoyed substantial support for aerospace power applications, for electric-utility power generation, and as a gas-utility cogeneration option in both the public and private sectors. However, automotive use of the fuel cell is a relatively new energy-conversion option which has virtually been ignored. Thls inactivity has becn baced on concerns regarding fuel supply and storage, as well as on the hilgh unit custs due to the ues of noble-metai catalysts in the electrode compuntuls. Recent advancco in fuel supply/storage technology, and in electrocatalysis, may do much to eliminate or alleviate these concerns. This assessment was undertaken to evaluate the current status of the fuel cell/battery power system--maln1y for the automobile. Fucl cells comprise electrochemical systems which undergo oxidation/ reduction reactions at catalyzed electrodes, and utilize appropriate electrolytes for ion transport, just as batteries do. Unlike batteries, fuel cells have a separate fuel container which can be sized for an appropriate range. The fuel may be in the form of pure hydrogen, or a suitable hydrocarbon such as methyl alcohol which can easily be reformed on-board to yield hydrogen plus inerts. Air (oxygen) is the oxidant. In the hydrogen-oxygen reaction at the electrodes, electrical energy is generated along with water; thils rhe futl cell is environmentally desirable.

Operating at high efficiency, the fuel cell can be designed for electric power consistent with cruise requirements. Higher power demands for acceleration or hill climbing can be accommodated by combining the fuel ceil with a low-storage-capacity/high-power battery subsystem. This battery can be charged during the cruise cycle, thus minimizing the possibility of lifedegrading deep discharges.

Clearly, the automotive fuel cell augmented by a power batlery can utilize technology being developed for alternative fuels; and, owing to its electrical output, ties in well with advances in electric motors, drive trains and ocher ancllidtles beling devcloped opecifisally for hattery-powered electric 
vehicles. Alternative fuels would be used more effectively because of the higher conversion efficiency of the fuel cell compared with the internal combustion engine. Rapid refueling and performance characteristics could be achieved consistent with user practices in the automotive sector.

D. SUMMARY STATUS OF FUEL-CELL RD\&D

In the vehicle propulsion context, the thrust of Industrial and Government support has been directed toward development of the storage battery rather than the fuel ce11. Intensive efforts are being made under the impetus of "The Electric and Hybrid Vehicle Research, Development and Demonstration Act of 1976 (Public Law 94-413)." Near-term, fleet-size battery vehicle demonstrations are emphasized, and there has been no implementation of system development for the automotive fuel cell. However, the Public Law specifles the development of fuel-cell propulsion systems as an additional or complementary activity.

The automotive industry maintains an awareness of fuel-cell technology, but is not involved in RD\&D efforts for readying this technology's application to current or future needs. The minimal activities in automotive fuel-cell development appear to persist, notwithstanding the significant and encouraging contributions of Dr. Karl Kordesch of Union Carbide. Dr. Kordesch demonstrated a converted compact car (Austin A-40) powered by an alkaline fuel cell, which ran on compressed hydrogen at ranges and speeds consistent with highway driving practices (see Appendix A).

Small-scale development and testing activities are ongoing at U.S. Army Mobility Equipment Research and Development Command (MERADCOM), Los Alamos Scientific Laboratory and Brookhaven National Laboratory. A current study by Lawrence Livermore Laboratory (LLL), "Energy Storage Systems for Automotive Propulsion," compares computer-modeled automobiles powered by internal combustion engines, by an alkaline fuel cell/battery system, by batteries alone, or by hybrids. This assessment was conducted as part of the LLL study, for the Chemical Energy Storage Panel, under funding supplied by the Division of Energy Storage Systems in the DOE.

E. COMPARATIVE POWER-SYSTEM AND FUEL COSTS

Current fuel-cell technology suggests system production costs in the range of $\$ 150-\$ 250 / \mathrm{kW}$ ( $1979 \$)$. These costs contrast marked1y with $\$ 10 / \mathrm{kW}$ for Internal combustion systems and $\$ 50 / \mathrm{kW}$ for diesel systems--both of which have 
been highly developed over the years. It is concelvable that future automotive fuel cells will become cost competitive, especially with focus placed on the development of electrodes which do not require noble-metal catalysts. Furthermore, fuel-cell fabrication does not require the high-precision machining which is essential to engines, thus reinforcing the probability of attaining the cost-reduction goals.

Fuel-cell cost projections must remain speculative due to the absence of a concerted effort in estimating production costs which would factor-in potential advances in the technology. For example, noble metals would not be required in advanced-alkaline fuel cells. Progress in hydrogen storage and hydrogen separation/purification, combined with on-board hydrocarbon or alcohol fuel reprocessing, can provide pure hydrogen $\left(\mathrm{CO} / \mathrm{CO}_{2}\right.$ free) to the fuel cell--a requisite for effective performance of alkaline fuel cells. The tie-in of these synergistic developments bodes well for future cost-competitive, efficlent, and clean vehicle power-system alternatives.

Fuel costs, considering only hydrogen and methanol as the most likely candidates, are expected to be a major cost element. Hydrogen can be made available by water electrolysis at costs below $\$ 20 / \mathrm{million} B t u$, depending upon capital and operating costs of electrolysis, the principal one being the cost of electricity. Coal-derived hydrogen and methanol can be produced at lower costs ranging from an estimated $\$ 8-\$ 15 / \mathrm{million}$ Btu.

Comparable gasoline cost (untaxed) at the refinery is estimated at $\$ 6 / m i l i t i o n$ Btu ( $\$ 0.75 / g a l l o n)$. Giving due consideration to the improved energy conversion efficiencies of fuel cells over that of the internal combustin engine, the cost disparities that currently exist can be largely eliminated. In addition, the more rapid cost escalation, as oil resources diminish, will make alternative non-petroleum fuels even more attractive.

Consideration must be given to the added costs associated with penetration of the energy infrastructure by hydrogen and methanol. This aspect must be addressed in order to assign a high degree of credibility to the automotive fuel-cell optlon.

F. POTENTIAL OF THE FUEL CELL/BATTERY SYSTEM

Integration of the fuel cell and battery represents a technological extension of advances currently pursued for automotive propulsion systems. This combination can provide broader capabilities over battery systems such as: 
more flexible over-the-road performance; extended driving ranges; rapid recharging; and no need for recharging from an electric-utility grid. The modularity of the fuel cell/battery system permits consideration of traction applications beyond passenger vehicles and vans. It can be used in spectal-purpose, pollution-free vehicles such as fork-1ift trucks, mine vehicles, as well as in vital trucks, inter-city buses, and rail systems.

G. RECOMMENDATIONS

- Initiate a focused research, development and demonstration program. emphasizing the development of low-cost automotive fuel-ceil systems. Provide for strong Federal support at the outset with an incrementally increasing role to be assumed by industry as the technology matures. The program could, under present statutes, be supported in the inftial stages, under DOE's Public Law 94-413 program. 


\section{SECTION 1 \\ INTRODUCTION AND SUMMARY}

A. TECHNICAL CONCEPT AND RATIONALE

A fuel cell/battery power system, as applied to vehicle propulsion, is an integrated electric drive system in which:

Sustaining power, as required for vehicle cruising, derives from fuel cells supplied by onboard chemical fuels, and

Transient power needs, beyond those for which the fuel cells are rated, are provided by a high-power-output storage battery, which is recharged by the fuel cells.

Usually, in such a system, the storage battery is recharged on the vehicle from the fuel cell as needed and whenever fuel cell power demand is less than its rated capacity. The fuel cell itself is operated on hydrogen fuel, supplied as such directly, or produced aboand from hydrocarbon or alcohol fuels via a "fuel processor." (Note: hydrazine and ammonia can be used as fuels also; hydrazine directly in the fuel cell.)

In this system concept, the electric vehicle (EV) is chemically fueled rather than being electrically charged from a utility grid. This leads to a much shorter "charging time" than is presently the case with battery electric vehicles.

Figure 1-l shows schematically, in two levels of detail, the functional makeup, anä the component interfacing within, a fuel cell/battery vehicle. $^{l}$ Although these diagrams are meant to be largely selfexplanatory, a comment un une cumpuntil, " the "fuel proccsэor" (the uppor diagram) or "reformer" (lower diagram), is necessary.

Fuel cells developed to date consume hydrogen as fuel directly, using the oxygen from air (or as directly supplied in some cases). Electrical energy is produced and water is formed as the reaction product. Where a hydrogen-containing fuel is used, rather than hydrogen itself,

* If required, (Not required if hydrogen fuel is supplied.) 

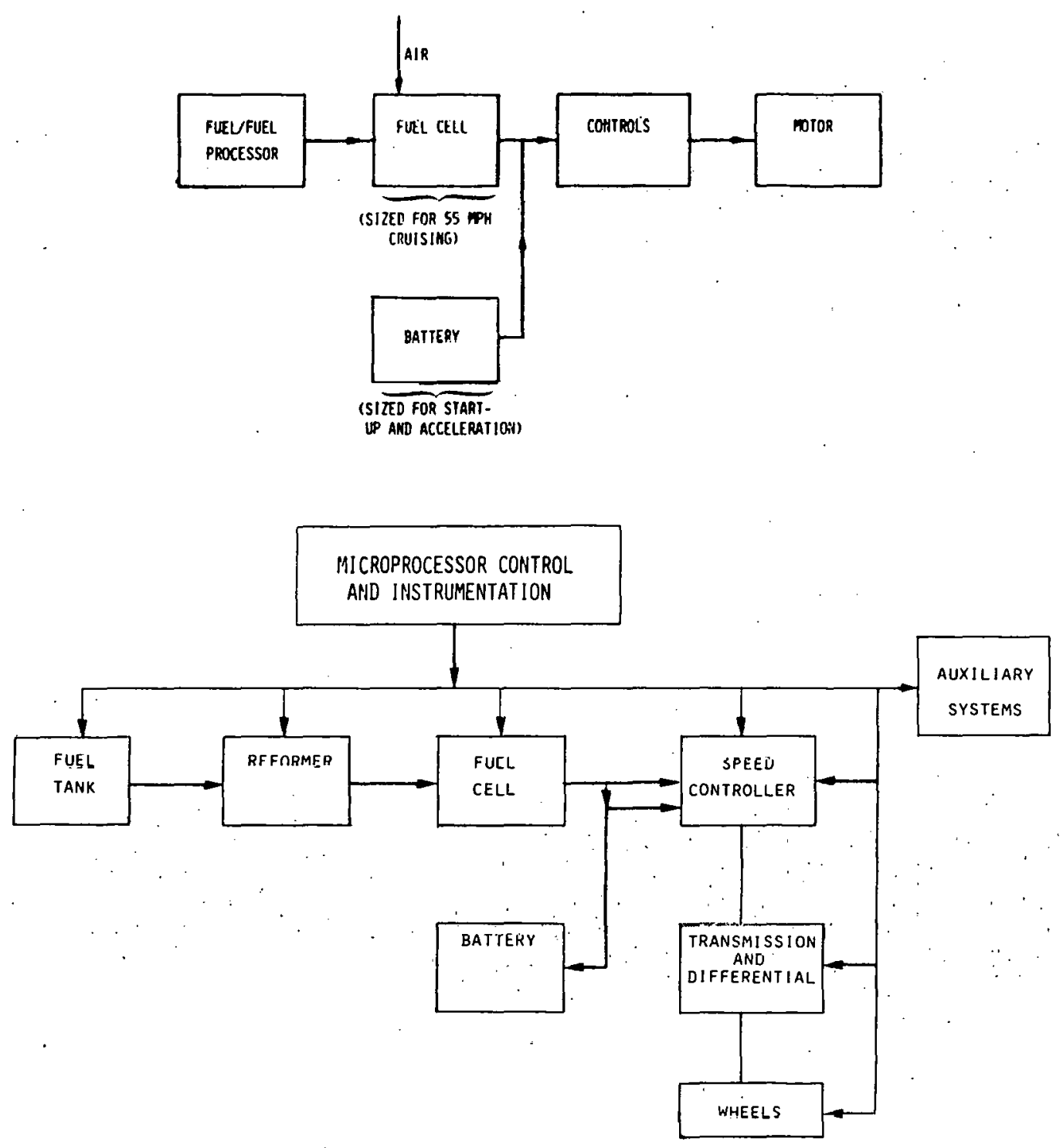

Mure detalled.system diagram.

Figure 1-1. Fuel Cell/Battery Vehicle Power System Functional Schematic Diagrams 1 
such as a liquid hydrocarbon or an alcohol, it must be first "processed" before it is usable in the fuel cell. Typically, in such cases, a hydrogen-containing gaseous product is produced from a liquid fuel. Steam reforming is an exemplary process; hence, the inclusion of a "reformer" in Figure 1-1 (lower sketch). In such systems carbon dioxide and other constituents, along with water, comprise the exhaust.

Why integrate the fuel cell and the battery in a common vehicle power system?. This question is pertinent since, to date, electric vehicle systems which have been developed and demonstrated have been mainly based on fuel cells, or much more extensively, batteries alone.

The reasons for considering this approach are:

1. A typical vehicle driving cycle requires only occasional high power output to meet transient demands (e.g., accelerations); most of the time - and for the bulk of the vehicle's energy expenditure - much lower power demands occur (e.g, sustained cruising conditions).

2. While selected batteries are effective producers of high power levels (to meet high but limited duration transient demand), they are limited in terms of total energy which can be supplied on a single charging (of relatively long duration, i.e., several hours).

3. A battery type and design that is best for meeting limited high power transients is ordinarily not optimal at storing maximum energy amounts. (In all-battery systems as is later discussed, this situation has led to the development of hybrid or dual battery/ battery systems which integrate two different battery types: a "power battery" and an "energy battery.")

4. Fuel cells, which can be viewed functionally as a special kind of "energy battery," are quite superior to any battery in that their electrical energy generation capacity is limited only by the amount of onboard fuel supply.

5. On the other hand, the "power battery" remains a more effective means of meeting the limited, high transient energy demands than the alternative of sizing-up the fuel cell complement to meet these requirements (for cost, weight, volume, and complexity reasons).

6. Thus, the integration of the two "best" elements - "power battery" and the "energy fucl cell" - is seen as a lonical option.

The hasir rnmplementary nature of the fuel cell and the battery can best be illustrated on a "Ragone Plot." This is a presentation of prime mover. specific power $(\mathrm{W} / \mathrm{kg})$ versus prime mover specific energy $(\mathrm{Wh} / \mathrm{kg})$. In this instance, "prime mover" is meant to comprise both the 
motive power device (e.g., heat engine, electric motor) and the fully

fueled/charged energy storage unit (e.g., fuel tank, storage battery).

Such a plot is presented on a log/log basis in Figure 1-2. On

it, three types of prime movers are reflected:

1. Heat engines (3 types), as curved quasi-horizontal curves in the upper right-hand area

2. Batteries (5 types), as downward curving lines in the lower-left and center of the plot

3. Fuel cells (2 types), as nearly horizontal lines in the lower center of the plot.

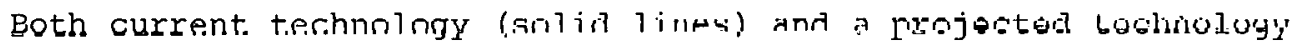

(dashed lines) are shown for the three categories.

Interpreting the plots, one can observe:

1. Heat engines, vis-à-vis batteries, have (1) a much higher specific power and (2) unlike batteries, an essentially unlimited specific energy (horizontal vs. near-vertical nature of the corresponding curves).

2. Fuel cells, vis-à-vis batteries, have roughly equivalent specific power, but - like heat engines - are essentially unlimited in specific energy.

3. Fuel cells, vis-à-vis heat engines, have an approximate orderof-magnitude lower specific power, but share the quasi-unlimited specific energy feature. Further, fuel cells provide for superior energy conversion efficiency as indicated by the lower slope (i.e., the more nearly horizontal trend) of their characteristir. curves.

One can nominally conclude that:

1. Heat engines can, in a single prime-mover type, provide high levels of sperific power and specific energy (their adequacy is testified to by the extremely widespread, nearly exclusive, use of heat engines for transportation system motive power).

2. Neither the fuel cell by itself (lacks specific power, hence leads to a more massive installation than the heat engines for equivalent power capability), nor the battery by itself (lacks epeciflc energy, hence leads to a limited range [endurance] system as compared with the heat engine) can deliver the combined power and energy output achievable with heat engines.

3. The integration of the fuel cell (sized to a given energy, or range/endurance requirement) and the battery (sized along with the additive fuel cell contribution to a given power requirement) into an optimal system offers the potential for achieving an acceptably equivalent performance characteristic of the heat engine. 
4. The superior energy conversion efficiency of the fuel cell provides the potential, in an optimal fuel cell/battery power system (Item 3, above), of lower specific energy (fuel) consumption in a transportation vehicle.

This, then, is the general rationale for current interest in the fuel cell/battery transportation power system as a potential new system which should be developed and deployed in appropriate vehicle systems.

There are also other important technical reasons for integrating the fuel cell and the battery, with reference mainly to considering either one alone, as the prime mover. Among these reasons are:

a. Long life and stable performance characteristics have been demonstrated with fuel cells, so that vehicle performance will not degrade, either over a driving cycle or over the life of the vehicle.

b. Long battery life can be achieved under the shallow discharge/ charge cycling anticipated in fuel cell/battery system operation (in contrast to deep, life-shortening cycling in conventional electric battery vehicle cycling).

c. The battery facilitates fuel cell system start-up and can prevent fuel cell voltage reversals (an undesirable characteristic of straight fuel cell power systems).

B. TECHNICAL AND PROGRAM STATUS OF TRANSPORTATION FUEL CELLS AND BATTERIES

Substantial improvements have been made in both fuel cell and battery technology during the last decade. However, whereas a focused programmatic thrust has been mounted to advance transportation battery development for all-battery vehicle applications, such is not the case for transportation fuel celis.

Rather, by comparison, only low-level funding has been allocated to transportation fuel cell development in comparison with that being spent on large electric and gas utility fuel cell systems, and space and military power generation applications. Although some of the nonvehicle power system fuel cell projects provide direct benefits to potential transportation applications, much of this work is believed to be largely inapplicable to transportation, e.g., molten carbonate fuel cells.

Tables 1-1 and 1-2 summarize technology advances for both fuel cells (generally) and batteries (transportation oriented). Whereas directed 


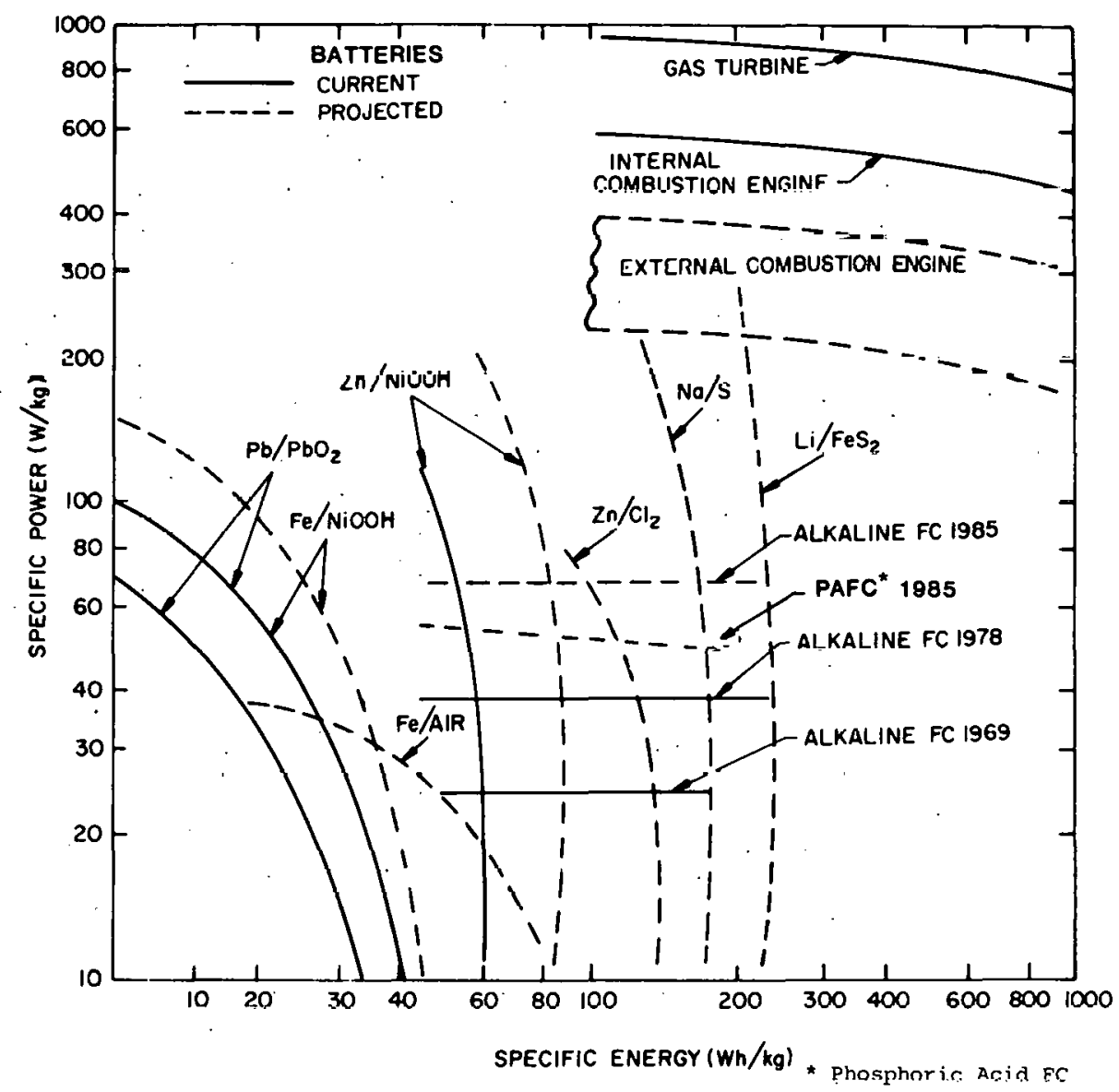

Figure 1-2. Ragone Pluts fur Batleries, Fuel Cells, and Various Heat Engines (Source: Brookhaven National Laboratory) 
Table 1-1. IMPROVEMENTS IN $\mathrm{H}_{2} /$ AIR FUEL CELLS

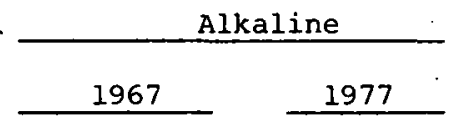

Currert Dersity (ma/ $\mathrm{cm}^{2}$ )

cell voltace (V)

Power Density $\left(\mathrm{mw} / \mathrm{cm}^{2}\right)$

Operating Temperature $\left({ }^{\circ} \mathrm{C}\right)$

Thermal Efficiency $(z)$

Catalyst Lcading $\left(\mathrm{mg} / \mathrm{cm}^{2}\right)$

Start-Up Time

Life (hours)

Source: Reference 1 .

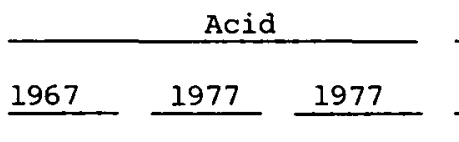

\begin{tabular}{c} 
SPE \\
\hline $1967 \quad 1977$ \\
\hline
\end{tabular}

100

200

300

300

400

$15-42$

700

0.75

0.7

0.55

0.65

0.6

$0.6-0.7$

0.68

75

140

165

195

240

$10 \cdot 5-25$

476

$65-75$

80

160

190

25

25

100

51

47

3.7

44

$<0.2$

20

0.75

4

40

46

3.5 hours

5 min. (1969)

5000
$>12,000 \quad 600$

1000 
Table 1-z. BATTERY FUNDING SHOWING PORTION ALLOCATED 50 EV BATTEF.IES $\left(\$ 10^{6}\right.$ )

\begin{tabular}{|c|c|c|c|c|c|c|}
\hline & \multicolumn{3}{|c|}{ FY 1979} & \multicolumn{3}{|c|}{ FY 1980} \\
\hline & $\begin{array}{c}\text { Total } \\
\text { Batteries }\end{array}$ & $\begin{array}{l}\text { Near-Term } \\
\text { Batteries }\end{array}$ & $\begin{array}{l}\text { Advanced EV } \\
\text { Batteries }\end{array}$ & $\begin{array}{c}\text { Total } \\
\text { Betteries } \\
\end{array}$ & $\begin{array}{l}\text { Near-Term } \\
\text { Batteries }\end{array}$ & $\begin{array}{r}\text { Advanced } \mathrm{E} \\
\text { Batteries }\end{array}$ \\
\hline Near-Term Batzeries & 6.33 & 6.33 & -- & $\subseteq .95$ & 9.95 & -- \\
\hline Advanced Batteries & 11.50 & -- & 8.53 & 14.40 & -- & 10.75 \\
\hline Sclar Applica=icns & 0.80 & -- & -- & 5.00 & -- & -- \\
\hline $\begin{array}{l}\text { Electrochemical System } \\
\text { Research }\end{array}$ & 2.50 & -- & 1.53 & 2.60 & -- & 1.63 \\
\hline Supporting Research & $\tilde{2} .1 .4$ & 0.38 & 0.42 & $\Xi .00$ & 0.83 & 0.59 \\
\hline Electrolytic Technology & 1.32 & -- & -- & 1.50 & - & 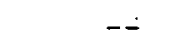 \\
\hline Dispersed Batzery Applizations & $\frac{5.90}{30.59}$ & $\frac{--}{6.71}$ & $\frac{--}{10.58}$ & $\frac{4.50}{4 C .95}$ & $\frac{--}{10.78}$ & $\frac{--}{12.97}$ \\
\hline
\end{tabular}

Nore: "Total Baiteries" column include ’rcgram elements, e.g., component te.chnologies efforts, other =han what is refresented; renze the cclumns do not azd up horizontally.

Source: Reference 2 . 
Table 1-2, Cont. PERFORMANCE PROJECTIONS FOR NEAR-TERM BATTERY PROGRAM

\begin{tabular}{|c|c|c|c|c|c|c|c|c|c|c|c|c|}
\hline & \multicolumn{4}{|c|}{ Lead-Acid } & \multicolumn{4}{|c|}{ Nickel/Iron } & \multicolumn{4}{|c|}{ Nickel/Zinc } \\
\hline & $\underline{1979 *}$ & 1980 & 1982 & 1984 & $1979 *$ & 1980 & 1982 & 1984 & $1979 *$ & 1980 & 1982 & 1984 \\
\hline Specific Energy $(\mathrm{Wh} / \mathrm{kg})$ & 34 & 42 & 50 & 50 & 48 & 54 & 58 & 60 & 60 & 64 & 67 & 70 \\
\hline $\begin{array}{l}\text { Specific Power (Wh/kg) } \\
-- \text { Peak (20 seconds o } 50 \%\end{array}$ & & & & & & & & & & & & \\
\hline State of Charge) & 80 & 90 & 95 & 100 & 100 & 110 & 120 & 120 & 110 & 140 & 140 & 140 \\
\hline $\begin{array}{l}\text {--Sustaired ( } 1 / 2 \text { hour } \\
\text { rate) }\end{array}$ & 35 & 40 & 45 & 50 & 70 & 80 & 90 & . 95 & 80 & 80 & 90 & 95 \\
\hline $\begin{array}{l}\text { Cells/Moc̄ules Cycle } \\
\text { Anticipa } \\
\text { bility (No. Cycles) }\end{array}$ & 300 & 300 & 500 & 750 & 800 & 1500 & 1800 & 2000 & 100 & 200 & 300 & 500 \\
\hline $\begin{array}{l}\text { Prociuction Capacity } \\
\text { Per Contractor (Batteries/ }\end{array}$ & 200 & مחه & חم 10 & 2000 & 50 & 100 & 300 & 500 & 40 & 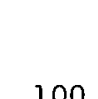 & 300 & 500 \\
\hline $\begin{array}{l}\text { Battery Frice \& the } \\
\text { Above Production Level } \\
\text { (\$/kWhr)(1979\$) }\end{array}$ & 100 & 100 & 80 & 60 & 1200 & 500 & 350 & 300 & 550 & 500 & 500 & 250 \\
\hline
\end{tabular}

* Only cell data $w i l l$ be obtained in 1979. Table values are estimates for batteries if assembled with these cells.

Source: Reference 2 . 
funding for program support is also indicated for the ongoing battery work in the table, none is shown for the fuel cell for reasons stated.

Not presented in Tables 1-1 and 1-2, but as will be discussed later in the report, cost estimates for such fuel cell systems, assuming production volumes, are in the $\$ 150$ to $\$ 250 / \mathrm{kW}$ range.

The significance of the technical and cost advances for fuel cells and batteries, reflected in this discussion, is that these gains are likely to be favorably compounded in the context of integrated vehicle power systems. Hence, it is surmised that a "new look" on a comparative basis with alternative systems could show substantial gains for the fuel cell/battcry system relative to the competition.

C. BACKGROITNN AND STATUS OF FUEL CELL/BATTERY VEIICLE POWER SYSTEMS ACTIVITIES

A limited number of experimental fuel cell/battexy powered vehicle systems have been assembled and demonstrated. These include:

Hydrazine fuel cell/nickel-cadmium battery powered motorbike, Kordesch, Union Carbide Corporation, ca. 1966.

- Hydrazine fuel cell/lead-acid battery powered automobile, williams et al., Shell Research, Ltd. (England), ca. 1967.

- Hydrazine fuel cell/lead-acid battery powered truck, U.S. Army/ Monsanto Research Corp., ca. 1968.

- Hydrogen fuel cell/lead-acid battery powered automobile, kordesch, Union Carbide Corp., 1971-1975.

- Hydrogen fuel cell/lead-acid battery powered fork lift truck, Dowglallo, et al., MERADCOM, 1975-1978.

- Hydrogen fuel cell/lead-acid powered golf cart, McCormick et al., L.NEL, 1070.

Additionally, several straight fuel cell powered vehicle systems (no batteries) have been demonstrated including a hydrogen-oxygen fuel cell powered tractor by Allis-Chalmers Manufacturing Co: in 1959 and the hydrogen-oxygen tuel cell powered "Electrovan" project of General Motors Corporation ca. 1965.

Appendix A presents a technical review covering all but the most recent of the above listed projects in a paper by Kordesch. Further information on a number of these projects is given throughout the report. 
All-battery powered vehicle systems development and demonstration activities are much more widespread, largely as a consequence of the impetus provided by the enactment of the Electric and Hybrid Vehicle Research, Development, and Demonstration Act (Public Law No. 94-413), passed on september 17, 1976. DOE is responsible for program implementation. 3 In view of the size and complexity of this program, no attempt to summarize it is included here.

A notable topical workshop on "The Fuel Cell in Transportation Applications" was held at LASL in August 1977 (Proceedings).1 The proceedings for this meeting provide a useful and nearly-current review of the relevant state-of-the-art.

\section{References Cited for Section 1}

1. McCormick, B., et al., ed., "Proceedings of the Fuel Cell Transportation Applications Workshop," held 15-17 August 1977, Los Alamos Scientific Laboratory Conference Proceedings LA-7270-C, issued July 1978 .

2. Katz, M.J., and Klunder, K.W., "The Department of Energy Electric Vehicle Battery Program: An Overview," DOE Presentation at the 14th Intersociety Enexgy Conversion Conference, Boston, August 5-10, 1979.

3. Anon., "Electric and Hybrid Vehicle Demonstration - 1978 ," Brochure DOE/CS-0046. 
THIS PAGE

\title{
WAS INTENTIONALLY
}

\author{
LEFT BLANK
}




\section{SECTION 2}

\section{OBSERVATIONS, CONCLUSIONS, AND RECOMMENDATIONS}

Based on the assessment's findings as discussed on a task-bytask basis in Section 4, this section presents the assessment team's sumary observations followed by its conclusions and recommendations, both general and specific.

$\underline{A}$. OBSERVATIONS

Status of Transportation Fuel Cell R\&D

Fuel cell research and development for vehicle power systems applications is not presently being pursued at significant levels of funding, as compared with R\&D support for 1) other fuel cell applications, particularly utility system use, and 2) vehicle batteries for all-battery and hybrid automotive use.

Benefits of the Fuel Cell/Battery Power System to Electric Vehicles

Based on the limited systems analyses and hardware demonstrations conducted to date, fuel cell/battery vehicle power systems appear to offer significant technical advantages and probably cost advantages over both all-battery and all-fuel cell power systems, specifically:

- Substantially extended range and endurance (and a markedly reduced battery complement) vis-à-vis all-battery systems

- Improved over-the-road performance and operating flexibility(and a renured fuel cell complement) vic-à-vis all-fuel-ccll systcm

- More rapid "recharging" by virtue of fueling procedures.

Present Industry and Government Involvement

At present, in the United States, industrial and Governmental organizations are involved in fuel-cell-based vehicle power systems activities at varying, but generally low levels of effort:

- Automotive industry organizations, although "maintaining awareness," are not actively engaging in applicable RD\&D. 
Fuel cell industry organizations, although active in utility and aerospace fuel cell projects, are not actively engaging in transportation-applicable fuel cell RD\&D.

- The substantially funded thrust (ca. $\$ 160$ million) by the Government (DOE) in electric and hybrid vehicle RD\&D (under Public Law No. 94-413), into which fuel cell vehicle applications seemingly would fit, does not presently provide support for fuel cell RD\&D.

- Low-level systems analyses and limited hardware R\&D in fuel cell/ battery vehicle power systems is underway at MERADCOM, LASL, and BNL, the latter two organizations being supported by DOE.

Overseas Involvement

Outside the United States in the sphere of EV RD\&D, fuel cell activities appear mainly absent. A focused activity is being pursued by ELENCO (see special note at the end of Section $4 \mathrm{E}$ ), and some activities have been reported in France and Sweden.

\section{Alternative Vehicle Applications}

Stress to date has been placed on specialty vehicles applications (e.g., fork-lift trucks), and private automobile as the "target market" for fuel-cell-based power systems. However, certain other vehicle types and service applications appear to offer favorable technical opportunities and economic. advantages. Hence, these transportation applications should also be vigorously pursued as fuel-cell appilications: railroad systems, intercity trućks, intercity and urban buses, and short-haul and urban delivery trucks and vans.

\section{Fuel Cell Relationship to the Electric Vehicle}

In the context of all-battery electric vehicle systems, the integration of the fuel cell to achieve an optimal composite fuel cell/battery power system is anticipated as a technically and programmatically feasible step. The dual "energy battery/power battery" system; well known to the electric vehicle community, may well serve as an in-being point-of-entry for the fuel cell as a special kind of energy battery for the fuel cell as a special kind of energy battery for "second-generation" EV's.

\section{Fuel Cell/Battery Vehicle Differences}

The principal external differences between projected fuel cell/battery powered vehicles and equivalent all-battery systems will be: 
- Fuel cell/battery vehicles will provide needed range extensions, faster "recharging," no performance degradation over the operating duty cycle (between fueling/charging), and will likely have rejected heat available, for compartment comfort heating.

- Fuel cell/battery vehicles will be more-or-less conventionally fueled, as opposed to being charged from the electric utility. (However, an option for providing utility hydrogen-via-electricity can be considered.)

\section{Implications of Methanol and Hydrogen Fuels}

Methanol and hydrogen as candidate fuels for fuel cell/battery vehicles have differing and far-reaching individual characteristics to: be considered in any selection process:

Methanol, being an easily handled and stored (though toxic) room-temperature liquid fuel, is generally preferred (over hydrogen) for its logistical and onboard storage advantages. Its use requires an onboard reformer with its attendant cost and operation complications (which, however, are less severe than would be the case with straight hydrocarbons) and onboard water storage. Its use essentially precludes the alkaline fuel cell (carbon oxide sensitivity problem). Also, because of possible reformer catalyst sensitivities, it may be important to specify a methanol purity level other than that of "fuel-grade" methanol.

- Hydrogen, although technically the ideal fuel, is judged a more difficult material to handle logistically, and especially, to store onboard vehicles (than methanol); its general safety aspects remain an issue of concern (particularly liquid hydrogen).

Coal as a Primary Energy Resource

Coal is viewed as a likely primary energy resource for producing hydrogen by gasification, and methanol by gasification and synthesis, using existing process technology: However, such coal-based fuel production facilities do not presently exist in the United States, with both hydrogen and methanol being derived principally from natural gas by steam reforming. The ultimate availability of coal-derived methanol and/or hydrogen is a complex issue. Involved are such factors as continuing natural gas availability, other (than fuel cell/hattery vehicle) demands, the ratc at which coal-mining and delivery can be expanded, and the availability of capital for constructing fuel-production facilities. 


\section{Estimated Costs of Fuels}

Estimated costs for methanol from coal and hydrogen from coal were observed to be over the following ranges (Exxon Research and Engineering co. estimates) : ${ }^{1}$

$\begin{array}{lc}\text { Methanol From Coal } & \frac{\$ 110^{6} \mathrm{Btu}(1980 \$)}{7.80-14.40} \\ \text { Hydrogen (Gas) From Coal } & 7.90-9.60 \\ \text { Hydrogen (Liquid) From Coal } & 16.70-19.20 \\ \text { Estimated Costs for Transportation riel Cells and } & \text { Rat.teries }\end{array}$

Estimated costs for transportation fuel cells and batteries, on an assumed production-level basis, were ubserved in lie present doooccmont to be:

Fuel Cells: $\quad \$ 150-\$ 250 / \mathrm{kW}$

Batteries: * $\quad \$ 60-\$ 300 / \mathrm{kWh} r$

(Note: See Sections $4 \mathrm{~A}$ and $\mathrm{B}$ and References cited therein.)

B. CONCLUSIONS

1. At present in the United States, there is no formal comprehensive program basis for the conduct of fuel cell/battery vehicle power systems research development, and demonstration.

2. If succcocfully developed and introduced into vehicle fleet service, fuel cell/battery vehicles will provide substantial energy conservation benefits over competing hcat engine systems because of the intrinsic high conversion efficiency of their electrochemically-based power plant. (However, it is premature to attomnt to quantify such savings since these will be highly dependent on vehicle type and seirvice, specitic driving cycie, and the specifics of the power system itsel.f.)

3. The introduction of fuel cell/battery power systems will provide a needed significant extension of ranye and endurance capabilities in present uleutris vehislcs, and may substantially improve their general over-the-road performance.

* Note: Whereas the fuel cell will be priced on its power rating $(\mathrm{kW})$, the battery element of a fuel cell/battery systcm is likely also to be priced primarily on its power rating, rather than its energy storage capacity (kWhr), as is conventional. 
4. By virtue of these entended capabilities, electric power systems are likely to be competitive in a much wider range of transportation vehicle application areas than is the case at present, some of which appear to offer quite favorable RD\&D and eventual market penetration opportunities.

C. RECOMMENDATIONS

General Recommendations

Based on the identified energy conservation and vehicle capabilities extension advantages of the fuel cell/battery transportation power system approach, and the present lack of a directed effort is support of this option, a focused research, development, and demonstration program element* is recommended to be initiated at the earliest practical opportunity.

If this recommendation is to be pursued, the following implementation considerations are offered:

1. It would appear that a strong Federal Government role will be mandatory in successfully launching such a program element, and a number of agencies would have obvious "charters" and capabilities for administering it, particularly DOE and DOT.

2. As an example of "placing" this recommended program element, it might well be integrated into DOE's ongoing electric and hybrid vehicle research, development and demonstration effort (mandated under Public Law No. 94-413).

3. In response to the anticipated opening up of vehicle application areas to the rail, trucking, and bus sectors (and possibly others), concerted efforts should be placed on early representation in the program element of the views and outlooks of these using sectors.

4. Finally, there will be a special need for a comprehensive, widely distributed, and appropriatcly updated program element planning document, as well as an active inter-organization liaison function to assist and coordinate the widespread implementation activities perceived as intrinsic to this effort.

Specific Recommendations.

Within the framework of the general recommendation, the following specific recommended actions are suggested:

* Referred to as a "program element" for reasons noted in Item 2, below. 
1. Mission and Systems Analysis of fuel cell/battery powered vehicles of all types of potential interest should be pursued aggressively and early. Existing computer simulation capabilities should be expanded and vigorously exercised, while needed hardware- and mission-related information is gathered (e.g., driving cycle data, servicing and maintenance constraints, and general operating environments).

2. Fuel cell and battery subsystem characteristics for designated transportation applications should be better defined; both needed general technical/cost advances and any potentially limiting technological gaps should be rapidly identified and appropriate RD\&D efforts documented for implementation. All potentially applicable fuel cell types should be encompassed, as should all candidate fuels.

3. Strong fuel cell/battery systems integration efforts are required wth emphasis on component malching and interfacing, and overall controller optimization. Integration with both the onboard fuel supply system and the vehicle final drive should be heavily stressed frull the onset. Active feedback to the component and subsystems R\&D activities should be maintained.

4. Well ahead of the formal demonstration phase, complete static laboratory and dynamic over-the-road engineering evaluation hardware systems should be constructed and operated at the earliest practical time. Such tools can initially comprise stateof-the-art components and subsystems, augmented by simulation techniques and progress to fully operable developmental vehicle systems using advanced hardware as this becomes available. Feedback to both the power systems and the component subsystem R\&D.efforts should be maintained.

5. Finally, in planning the demonstration phase of the fuel cell/ battery system program element, it is highly recommended that the general "learning experience" of previous Federally-supported demonstration projects be very carefully heeded, e.g., the assessment by Rand. ${ }^{2}$ Proceeding from this reference, as pointed out in a recent Assessment of Alternative Fuels for Intercity Trucking, 3 the real purpose of the demonstration is to reduce uncertainties, of which five specific types are cited:

"1. Technological Uncertainty: uncertainty about the feasibility of a technology for a certain use.

2. Cost Uncertainty: uncertainty about the monetary cost of manufacturing a product or operating a proress or system using the technoloqy.

3. Demand Uncertainty: uncertainty about the benefits (private or public) that will accrue from the use of the technology.

4. Institutional Uncertainty: this uncertainty dimension is divided into two categories: 
a. Internal: uncertainty about the impact of adoption on the functioning and structure of the adopting organization.

b. External: uncertainty about the impact of adoption on the adopting organization's relationship with other organizations such as unions or competitors.

5. Uncertainty about Externalities: uncertainty about costs and benefits that are not counted for and the price of either factor: inputs or output. This dimension includes such questions as: Is the technology or its outputs safe? Does it increase or lessen pollution, health hazards, or the like?"2

\section{References Cited in Section 2}

1. Cart, E.N., Jr., Carter, D.A., and Cunningham. A.R., "Alternate Energy Sources for Non-Highway Transportation," Appendixes for Volume II-B, prepared for the U.S. Department of Energy by the Exxon Research and Engineering Company under Contract No. DE-ACO5-77CSO5438.

2. Baer, W.S., Johnson, L.L., and Merrow, E.W., "Analysis of Federally Funded Demonstration Projects: Final Report," prepared for the Experimental Technology Incentives Program of the U.S. Deparment of Commerce by the Rand Corporation, R-1926-DOC, Santa Monica, California, April 1976.

3. Foster, R.W., "Alternative Fuels and Intercity Trucking," DOE Report HCP/M 3294-01, June 1978. 
THIS PAGE

\section{WAS INTENTIONALLY LEFT BLANK}




\section{SECTION 3}

\section{OBJECTIVES AND SCOPE OF ASSESSMENT}

This section briefly states the objectives of the assessment and describes the technical scope of the effort.

A. OBJECTIVES OF THE ASSESSMENT

The primary objective of the effort reported here was to assess the status of the fuel cell/battery vehicle power system concept. This vehicle design approach is briefly :covered from a technical standpoint in Section 1 and from an engineering history viewpoint by Kordesch, in Appendix A, as well as elsewhere in the report.

The specific objectives of the assessment are noted below:

1. Perform a literature search on fuel-cell powered automobiles, vans, trucks, and lift trucks. Define the technical problems, evaluate the near-term and market potentials, assuming there is a source of fuel. (See section $4 A$, p. 4-1.)

2. Obtain the current views of DOE, GM, Ford, and MERADCOM on electric vehicles using a fuel-cell/battery combination (battery designed for 5 minutes of initial operation and for supplementary power during acceleration). Summarize work in progress by these organizations and their future interests in such vehicles. (See Section 4B, p. 4-12.)

3. Define the $R \& D$ focus required to make automotive fuel cells a viable transportation option, i.e., to effect a substantial market penetration. Determine which Government agencies, and organizations within, have funding responsibility. (See Section $4 \mathrm{C}$, p. 4-22.)

4. Evaluate the relationship between battery-driven and fuel cell/ battery driven vehicles, i.e., common technical problems and system components, as well as the respective advantages. Discuss how fuel-cell-driven vehicles might be affected in the market place due to the presence of battery-driven vehicles. (See Section 4D, p. 4-29.)

5. Obtain current views and outlooks of DOE and industrial organizations regardiny lie fulure availalility of $h_{z}$ drogen and methanol derived from coal. (See Section 4E, p. 4-36.)

6. Prepare project report. 
These objectives defined six tasks comprising the overall assessment. The findings resulting from these task activities are presented in Section 4.

One additional task was introduced during the course of the study: preliminary assessment of comparative vehicle simulation results. This added effort is in recognition of the value of having the results of computer-simulated driving-cycle performance for various fuel cell/ battery vehicle power systems available for comparative analysis. The simulation work discussed in Section 4 derives from the computer-based analysis carried out by Drs. B. McCormick and D. Lym of the Los Alamos Scientific Laboratory. (See Section 4F, p. 4-54.)

B. SCOPE OF THE ASSESSMENT

As sponsored by the Brookhaven National Laboratory (BNL), under Consulting Subcontracts 2690 and 2715, Escher:Foster Technology Associates, Inc. (E:F) carried out this assessment of the status of fuel cell/ battery vehicle power systems during June through September 1979. This effort was supported under the Lawrence Livermore Laboratory cooperative study, "Energy Storage Systems for Automotive Propulsion", with funding provided by the Department of Energy, Division of Ënergy Storage Systems.

The assessment effort reported here was of a specific, focused nature rather than being exhaustive or comprehensive. As noted in the objectives, previously presented, responses to specific questions were desired. A general review of work-to-date in fuel cells for vehicle power systems, coupled with a summary of attitudes, views, and plans, if any, of involved groups in industry and Government comprised the hasic target toward which the assessment team's efforts were directed.

Mr. Gerald Strickland of BNL managed the subcontract as Chairman of LLL's Chemical Energy Storage Panel. Messrs. William J. D. Escher and Richard W. Foster comprised the E:F assessment team. Mr. Raymond R. Tison assisted in fuels-oriented analysis reported in Section 4E. The E:F contribution required approximately $1-1 / 2$ man-months of effort. 


\title{
SECTION 4
}

\section{TASK FINDINGS}

\section{A. LITERATURE SEARCH RESULTS}

\section{Objective of Task}

The specific language of the Task $I$ assignment was:

\begin{abstract}
"Perform a literature search on fuel-cell powered automobiles, vans, trucks and lift trucks. Define the technical problems, evaluate the near-term and market potentials assuming there is a source of fuel."
\end{abstract}

Under Task 1 , the study team carried out a limited literature search covering the use of fuel cells in surface-transportation vehicles. Particular emphasis was placed on citations relating directly to fuel cell/ battery power systems for transportation applications. Based on the findings, an assessment of technical problems and the potential for future market penetration by such systems was prepared. This assessment was both task-related and, more generally, carried out to provide an overall basis for this effort. Therefore, in this respect, the findings are incorporated throughout the report as well as in this section.

\section{Approach}

Since an exhaustive search of the fuel cell literature was beyond the scope of the assignment, a "focusing means" was sought to permit the identification of immediately relevant citations. Such a means was found in an initial caanning of bibliographies (e.9., ASME, SAE); proceedings (e.g., Intersociety Energy Conversion Engineering Conference [IECEC]), and Journal of Technical Articles (e.g., Automotive Engineering, International Journal of Hydrogen Energy), and technical reports (e.g., from ERDA, DOE, and NASA).

The scope of the search has been limited to transportation aspects of the reportcd fuel cell work. Literature published by the society of Automotive Engineers proved to be reasonably comprehensive in subject coverage. This was augmented by additional literature deriving from the assessment team's direct contacts with workers in the fuel cell/transportation field. 


\section{Presentation of Finäings}

Selected references are presented as a bibliography at the end of this section.

On the specific subject of demonstration vehicle systems employing fuel cell and fuel cell/battery power systems, Appendix A provides an excerpt of a recent paper by Kordesch, in which he briefly notes past hardware-oriented vehicle projects. As noted, this survey does not include the recent and ongoing fuel cell/battery powered fork-lift truck of MERADCOM or the golf-cart test unit of LASL.

For completeness in the state-of-the-art roview sense, the reader is also advised to review the results of the assesment team's contacts with selected representatives of industry and Government (including several national laboratories) reported on in the next section (Section 4B).

The Transportation Fuel Cell vis-à-vis Battery Literature

Fuel cells, as applied to surface vehicle propulsion have a rather limited and uneven background, one extending roughly over the decades of the 1960's and 1970's. Efforts involving the combined fuel cell/battery power system represent a more limited subset of this field, being first demonstrated in operating systems in the late 1960's and early 1970's by Shell Research Ltd. and Union Carbide Corp. (See Appendix A.)

on the other hand, the much more extensive battery development activities for vehicle power systems applications have led to a very extensive technical literature base (not covered by this assessment). The U.S. work in batteries has been accelerated by support programs related to the focused thrust associated with the enactment of the Ellectric and Hybrid Vehicle Research, Development, and Demonstration Act of 1976 (Public Law No. 94-413).

The summary point appears to be that improvements in available, and projected-to-be-available battery capabilities, resulting from funded and ongoing battery vehicle development and demonstration projects, 
will support the battery subsystem of future fuel cell/battery vehicle power systems. However, some battery development to this end is indicated.

\section{Background for Transportation Fuel Cell Systems}

A broad-ranging review and prognosis covering fuel cell systems as transportation power systems is given by Schlatter in a 1967 paper (see bibliography section), in which he stresses the very major technical and economic impediments to be overcome (at that time).

He contrasts the $\$ 3 / \mathrm{kW}$ internal combustion engine* with a "most optimistic" $\$ 50 / \mathrm{kW}$ fuel cell, citing the lowest quoted estimate for production fuel cells of $100 \mathrm{~kW}$ and larger capacity by ASEA of Sweden as $\$ 500 / \mathrm{kW} . * *$ He sums up prospects with the statement:

"Even granting fuel cell breakthroughs, it is unlikely that fuel cell power will offer spectacular advantages over internal combution engine power. Vehicle applications which do develop may be expected first in specialty lines, not to any extent in private automobiles."

Schlatter notes that "fuel cells may someday replace some batteries in electric vehicles" (thus suggesting the basic rationale of the fuel cell/battery power system as covered in section 1).

In his prepared comments on Dr: Schlatter's 1967 survey paper, John C. Orth of the U.S. Army Engineering Research and Development Laboratories, offers the following:

\footnotetext{
"This paper shows that today's conventional concept of both fuel cell power plants and electric vehisles is inadequate for practical fuel cell
}

\footnotetext{
* For a $100 \mathrm{hp}$ automobile engine, this denotes a unit massproduction cost of about $\$ 400$. Escalating this cost at $6 \% /$ year to 1979 roughly doubles this to $\$ 800$, or $\$ 6 / \mathrm{kW}$.

** Present prospects for fuel cell and battery costs are discussed later (p. 4-8).
} 
powered vehicle propulsion. However, the stateof-the-art does change and there are today proposals being entertained for unconventional approaches to both fuel cell concepts and vehicle configurations."

Swinkels of GMRL provides a broad technical view in this 1968 paper, "Electrochemical Vehicle Powerplants:"

"It is probably useful at this point to destroy the mental picture one has of a battery as consisting of two dissimilar plates placed in an aqueous solution. This is the form most. conventional batteries have taken but it is unlikely that this type of electric powerplant will drive anything but a low performance, limited range vehicle.

"Neither the substance producers* nor the energy producers (that is, fuel cells and primary batteries) are of interest here but rather a combination of the two with the primary function of storing energy. We will, therefore, define a battery as a black box into which we can put a given amount of electrical energy, store it in the form of chemical energy, and retrieve a smaller amount of ejectrical energy at a later time." (emphasis and footnote added).

\section{Hybrid Battery Concept}

An all-battery analogy of the fuel cell/battery power system is the so-called hybrid battery system, for which several references were examined. Laumeister of the General Electric Co. describes the operation of a lead-acid (energy battery)/nickel-cadmium (power battery) in GE's "Delta" (for Developmental Electric Town Auto) vehicle in an SAE paper of 1968 .

In the following quotations from this reference, the term "drain rate" refers to discharge rate as related to power density (watts/pound), high

* Devices which accept electrical energy and materials and produce a new material(s), e.g., water electrolyzer, a secondary storage battery in its charging mode. 
values of which are associated with the nickel-cadmium "booster battery." The "main battery" in the GE system, a lead-acid unit, is used for its high energy density, which would be provided by the fuel cell in the system concept being assessed in the present report.

"The hybrid battery concept, as applied in the GE experimental vehicle, is a solution to the limited drain rate problem for most vehicle applications. A cadmium battery capable of very high discharge rate is paralleled through electronic control circuitry to the main battery. This circuitry automatically senses the drain rate and brings on and gradually increases the current delivery from the nickel-cadmium booster as the load increased beyond the economical capability of the main battery. The control circuit also automatically recharges the booster unit when it is not delivering current. The recharge is cut back to a trickle level once the booster is recharged and cut off when the vehicle key is turned off.

"The hybrid or booster battery system cannot solve the drain rate problem for all batteries. The main battery must have a sufficient power delivery rate to propel the vehicle at continued steady cruise up to its maximum recommended speed. The booster unit, while providing power for occasional hill climbing peaks, will not be recharged during cruising unless the main battery's output exceeds the cruising rate power demand. This relationship must be closely studied when considering high energy density, low drain rate batteries, since the battery weight will be determined by the drain rate factor (not the desired range) and may require a unit as heavy as the present lead acid."

In a later SAE paper (1971), Brown of GE further describes this hybrid battery approach and, addressing control and interconnection requirements, states:

"The batteries cannot simply be placed in parallel; they require a resistive connection between them and a variable connection to the load that protccts the main battery from excess drain rates in meeting local demands and in recharging the acceleration battery. The resulting performance offers the advantage of reduced main battery weight, extended range, and responsiveness to acceleration demands." 
Dalin and Kober of the Yardney Battery Corporation, in a 1969 SAE paper, describe another hybrid battery system for vehicle propulsion. A nickel-zinc battery is employed as the energy battery and an air-zinc battery* as the power battery. Nickel-cadmium batteries are rejected for widespread vehicle application because of the limited availability and high cost of cadmium, and the low energy density of the unit.

The Yardney researchers state that their work is predicated on non-use of any noble metal catalysts, which is believed to be incompatible with significant commercialization. Also, possible problems in recharging the nickel-zinc (power battery) from the energy battery are noted: e.g. the power battery might degrade under fast-charging conditions, as would be likely under normal driving cycle operation.

Finally, this paper reflects how the overald hybrid battery energy density (Wh/lb) and power density $(W / l b)$ characteristics can be tailored as a function of the mix of two battery types chosen. This mix is suggested to be a strong function of the vehicle type and, especially, the driving cycle involved.

\section{Fuel Cell/Battery Power Systems}

A non-vehicle fuel cell/battery power system consisting of a closely integrated molten carbonate fuel cell and a molten electrolyte battery is suggested by Frysinger in his 1969 SAE paper. He emphasizes the fast transient load response of this combination in stationaryapplication service.

A concise review of fuel cell and fuel cell/battery vehicle power system developments which reached the hardware stage is provided by

* Tnterestingly, "air srruhhing" to remnve sarhnn ninxide is assumen for the air-zinc battery as was done by Kordesch for the hydrogenair fuel cells used in his demonstration automobile. (See Appendix A.) 
Kordesch in his 1977 paper. This paper, as reproduced in the proceedings of the LASL Workshop (McCormick et al., 1977), is excerpted as Appendix A of this report. The reader is referred to this in lieu of repeating this coverage here.

Breele of the Institut Francais du Petrole presented a planning paper before the SAE in 1974 on hydrogen fuel cells, demonstrating its practicability in a 4-passenger urban automobile. He notes a cost-competiveness with conventionally fueled thermal engine automobiles, and concludes:

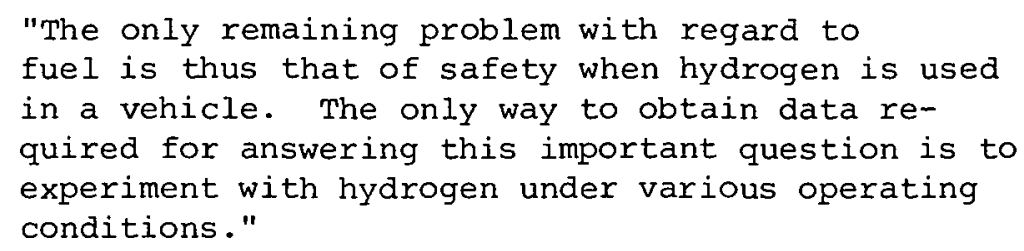

In a 1978 review of recent overview papers of electric vehicle development and demonstration programs for the United States (Esposito, Dustin and Denington), the United Kingdom (Samuel), and the Federal Republic of Germany (Brader and Stephan), no fuel cell activity is cited.*

In his 1978 paper, Dowgiallo of MERADCOM summarizes the substantial work with a fuel cell/battery system powered fork-lift truck during the period from 1975-1978. This project is discussed in following section 4B.

The current cooperative effort involving MERADCOM, LASL, and BNL was summarized at the 1979 IECEC (MCCormick et al.). The earlier proceedings of the 1977 "Fuel Cell in Transportation Applications Workshop" held at LASL provides a comprehensive technical review of the status of the applicable technologies. This cooperative effort is a continuing activity.

Not yet reported is the recently completed LASL golf-cart engineering system using a hydrogen-fueled phosphoric acid fuel cell/battery power system. Operation of this unit was achieved in september 1979.

However, a substantially funded and continuing effort by a joint Dutch/Belgium group (ELENCO) on transportation fuel cells is underway. See special note at the end of Section $4 \mathrm{E}$. 
Walsh, of the Argonne National Laboratory, has presented a recent (April 1979) review of the status of advanced batteries in the context of electric vehicle usage.

\section{Current Estimates of Vehicle Fuel Cell Costs}

Regarding current estimates of transportation fuel cell costs, in their 1979 IECEC paper, McCormick et al. cite: $\$ 200 / \mathrm{kW}$ for an automotivesized (15 kW). methanol fuel cell/reformer system. This is a phosphoric acid electrolyte unit.

Recent estimates for solid polymer electrolyte (SPE) type fuel cell by General Electric Co., the principal developer of this technology, are less than this:

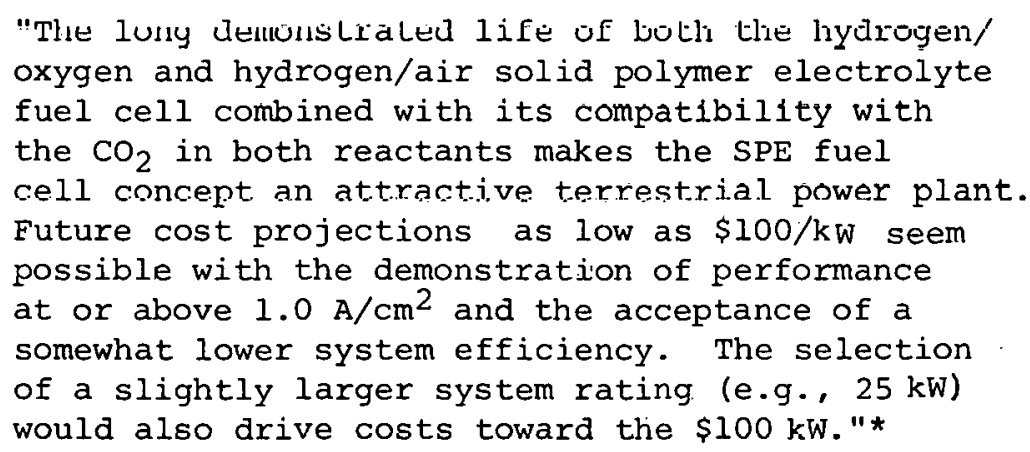

Recently published (1978-1979) information on vehicle alkaline fuel cell costs was not found in this assessment. A 1974 French reference (Breele) cites an 11.b-kW hỹarogen-air ruel cell (presumed lu be an alkaline) unit cost of $\$ 560$. The specific system cost is thus a low $\$ 50 / \mathrm{kW}$. Current Estimates of Vehicle Battery Costs

Katz and klunder of DOE provide est1mates of costs fur three nearterm vehicle batteries for a range of assumed production levels for the period of from 1980-1984. This information is summarized below

\footnotetext{
However, as discussed with MCElroy in a visit to GE on 8 August 1979, - a cost estimate of $\$ 200 / \mathrm{kW}$ was offered.
} 
for the 1984. case. (See also earlier Table 1-2):

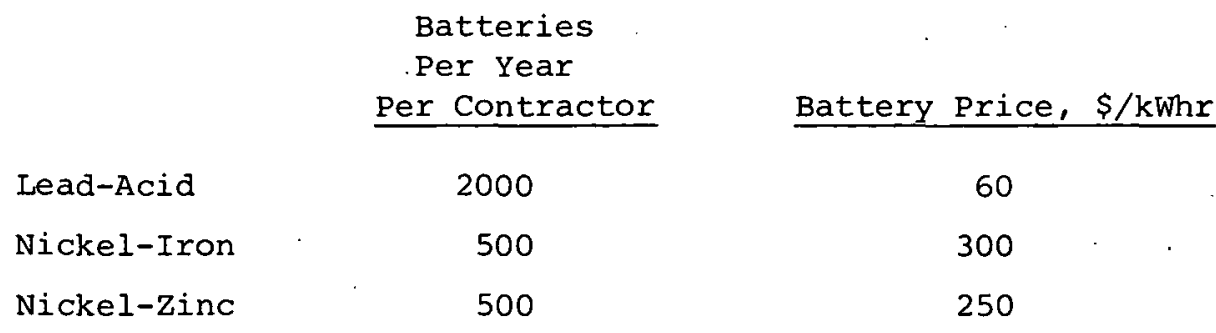

Again, the all-battery electric vehicle is the intended use for the batteries covered in the above estimates. It has been noted (e.g., by MERADCOM) that batteries for fuel cell/battery systems may have some-differeing technical requirements which should be addressed at an early point. It is not possible to estimate the related impact on price, if any.

\section{Bibliography for section $4 \mathrm{~A}$}

Amann, C.A., and Skellenger, G.D., "Developing an Electrically Driven Hydrogen Blower for a Vehicular Fuel Cell Powerplant," SAE Technical Paper No. 670455, 1967.

Andrew, M.R., Gressler, W.J., Johnson, J.K., Short, R.T., and Williams, K.R., "A Fuel-Cell/Lead-Acid-Battery Hybrid Car," SAE Technical Paper No. 720191,1972 .

Andrew, M.R. Gressler, W.J., Johnson, J.K., Short, R.T., and Williams, K.R., "Auxiliary Services for a Fuel-Cell Hybrid Electric Car," SAE Technical Paper No. 720192, 1972.

Anor., "Hydrogen as a Fuel," a Report by the Hydrogen Panel of the Committee on Advanced Energy Board Assembly of Engineering, National Research Council, National Academy of Soience, Wachington, D.C., 1979.

Bader, C., and Stephan, w., "Electric Vehicles in Germany - Present and Future," SAE Technical Paper No. 780087, 1978.

Breele, Y., "Using Hydrogen Fuel Cells for Urban Transportation," SAE Technical Paper No. 740168, 1974.

Brown, D.H., "Hybrid Battery System," SAE Technical Paper No. 710236, 1971. 
Cook, N.A., "Analysis of Fuel Cells for Vehicular Applications," SAE Technical Paper No. 680082, 1968.

Dalin, G.A., and Kober, F.P., "A Hybrid Battery System for Electric Vehicle propulsion," SAE Technical Paper No. 690203, 1969.

Dowagiallo, E.J., "A Fuel Cell-Battery Power Source for Electric Vehicles," MERADCOM presentation at the Fifth International Electric Vehicle Symposium, 2-5 October 1978, Philadelphia.

Dustin, M.O., and Denington, R.J., "Test and Evaluation of 23 Electric Vehicles for State-of-the-Art Assessment," SAE Technical Paper No. $780290,1978$.

Esposito, V.J., "Uverview of Electric Vehicles in the United states," SAE Technical Paper No. 780085, 1978.

Frysinger, G.R., "Fast Transient Response Fuel Celi Battery Hybrid Power Source," SAE Technical Paper No. 690205, 1969.

Katz, M.J., and Klunder, K.W., "The Department of Energy Electric Vehicle Battery Program: An Overview," DOE presentation at the 14 th Intersociety Energy Conversion Engineering Conference, 5-10 August 1979, Boston.

Kirkland, T.G., and Looft, D.J., "Fuel Cells - present Status and Development Problems," SAE Technical Paper No. 660230, 1966.

Kordesch, K.V., J. Electrochem. Soc. 118, 815 (1971).

Kordesch, K.V., International Society of Electrochemistry, 28th Meeting, September 1977. (Note: excerpted in Appendix A.)

Laumeister, B.R., "The GE Electric Vehicle," SAE Technical Faper No. $680430,1968$.

Marks, C., Rishavy, E.A., and Wyczalek, F.A., "Electrovan - A Fuel Cell Powered Vehicle," SAE Technical Paper No. 670176, 1967.

McBreen, J. and Srinivasan, S., "The Development of Alkaline Fuel Cell 'l'echnology for 'l'ransportation and uther Applications," Brookhaven National Laboratory Proposal, 1979 (limited distribution draft).

McBreen, J. et al., "Development of Fuel Cell Technology for Vehicular Applications," Brookhaven National Laboratory, Annual Report for Fiscal Year 1978, November 1978. 
Mc Cormick, B., et al., ed., "Proceedings of the Fuel Cell in Transportation Applications workshop," held 15-17 August 1977, Los Alamos Scientific Laboratory Conference Proceedings, LA-7270-C, July 1978.

McCormick, B., et al., "Applications Scenario for Fuel Cells in Transportation," Los Alamos Scientific Laboratory Informal Report LA-7634-MS, February 1979.

Mc Cormick, B., et al., "Applications of Fuel Cells in Transportation," combined LASL, Energy Research Group, Inc., BNL, and MERADCOM Presentation at the 14th Intersociety Energy Conversion Engineering Conference, 5-10 August 1979, Boston.

McElroy, J.F., "An Assessment of the Solid Polymer Electrolyte Fuel Cell for Mobile Power Plants," General Electric paper presented at the 28th Power Sources Symposium, 12 June 1978, Atlantic City, N.J.

O'Sullivan, J.B., Dowgiallo, E.J., and Snellings, I.R., "Hybrid Power Source for Material Handling Equipment," MERADCOM presentation at the 10th Intersociety Energy Conversion Engineering Conference, 18-22 August 1975, Newark, Delaware.

Samuel, J.M.G., "U.K. Electric Vehicle Development Programmes," SAE Technical Paper No. 78088, 1978.

Schlatter, M.J., "An Evaluation of Fuel Cell Systems for Vehicle propulsion," SAE Technical Paper No. 670453, 1967.

Swinkels, D.A.J., "Electrochemical Vehicle Powerplants," SAE Technical Paper No. 680452, 1968.

Walsh, W.J., "Advanced Batteries and the Outlook for the Electric Vehicle," Argonne National Laboratory paper presented to the 5lst Annual Meeting of the Lead Industries Association, 9 April 1979, Chicago.

Williams, K.R., Andrew, M.R., Gresslex, W.J., and Johnson, J.K., "Liquid Fuel/Air Fuel-Cell Power Systems," SAE Technical Paper No. 700022, 1970.

Winters, C.E., and Morgan, W.L., "The Hydxogen-Oxygen Thin Electrode Fuel Cell Module," SAE Technical Paper No. 670182, 1967.

Wyczalek, F.A., Frank, D.L., and Smith, G.E., "A Vehicular Fuel Cell System," SAE Technical Paper No. 670181, 1967. 


\section{B. CURRENT VIEWS AND WORK IN PROGRESS}

\section{Objective of Task}

Under Task 2 of the assessment, the study team carried out liaison with Government and industry personnel in order to -

"Obtain the current views of DOE, GM, Ford, and MERADCOM on electric vehicles using a fuel-cell/battery combination (battery designed for 5 minutes of initial operation and for supplementary power during acceleration). Summarize work in progress by these organizations and their future. interests in such vehicles."

\section{Approash}

The assessment team proceeded on this task effort through direct contact with the designated Government and industry organizations, namely, the U.S. Department of Energy (DOE), the U.S. Army Mobility Equipment Research and Development Command (MERADCOM), General Motors Corporation (GM), and the Ford Motor Company. This liaison was performed through facility visits, with the exception of MERADCOM, whose representatives were contacted by telephone and met with at locations other than Fort Belvoir, Virginia. A number of other contacts were also made. (See Table 4-1, p. 4-21.)

\section{Summary of Findings}

A summary of findings of current views and work in progress by the automotive industry and by the Government and national laboratories is presented below.

\section{Automotive Industry Contacts}

1. The automotive industry is not presently carrying on transportation fuel cell applications research and development which would be supportive of fuel cell/battery vehicle power systems.

2. However, the industry sustains an active interest in the potential of the fuel cell, associating it most directly with further advancuments beyond battery power syatema in elnotiric vehicles. 
3. Industry contacts generally reacted to the assessment team's contacts by inquiring if any advances in fuel cell costs, weights, volumes, and operating complexity had occurred to rekindle interest in fuel cells for vehicle use.

4. Of the methanol and hydrogen fueled alternatives considered in the present assessment, the possibility of methanol use in onboard reformer units was more readily accepted by industry contacts than hydrogen itself, although some interest has emerged in the latter at one company.

5. A specific concern was expressed about the potential supply limitations for the platinum group catalysts used in fuel cell electrodes if true automotive production volumes are ever to be achieved.

\section{Government and the National Laboratories*}

6. The thrust of current Government-supported fuel cell work is not directed to surface transportation applications but rather to 1) the electric utility, and 2) spacecraft and aircraft power system applications. (However, see Items 7, 9, and 10, below.)

7. The only pertinent fuel cell/battery vehicle system activity noted is that being cooperatively carried out by the U.S. Army MERADCOM, LASL, and BNL, with the former having operated an actual fork-lift truck using this system over realistic duty cycles in the laboratory during the period from 1975-1978.

8. Programmatically, the DOE electric vehicle activities being carried out under Public Law No. 94-413 (electric and hybrid research, development and demonstration act) exclude the fuel cell. It is not included in the extensive and continuing study effort on "Energy Storage Systems for Automobile Propulsion," being led by Lawrence Livermore Laboratory (LLL) (even though hydrogen systems for internal combustion engines are included).**

9. Existing and ongoing work in the field of fuel cell/battery power systems appears presently limited to -

- A MERADCOM fork-lift truck outfitted with a metal-hydride hydrogen storage system by Billings Energy Corporation (partly supported by Brookhaven National Laboratory).

* Note: Generally, the efforts being carried out at the national laboratories are supported by the U.S. Department of Energy.

** However, subsequent to the preparation of the present report, fuel cell power systems for automobile propulsion wcre cited in the LLL report in the series (Draft UCRL-52841, Vol. 2, September 1979). 
- Modified golf-cart test vehicle recently completed by Los Alamos Scientific Laboratory (LASL) operating on onboard pressurized gas cylinders of hydrogen. (two steel breathing-air tanks).

- Continuing vehicle/driving cycle computer simulation studies at LASL, including the technoeconomic characterization of several highway vehicle systems (city bus, highway bus, delivery van, and automobile).

10. A modest effort entitled "Development of Fuel Cell Technology for Vehicular Applications" is in its second year at BNL, in which alkaline (KOH), phosphoric acid, and solid polymer electrolyte fuel cell technology is being experimentally pursued at small scale.

\section{Discussion of Automotive Industry Contacts}

In discussiuns with representatives from the Ford Motor Company's Scientific Research laboratories and the General Motors Research Laboratories, we gained the impression that there is no work of any magnitude presently underway on the fuel cell/battery power system concept. Outside of some basic electrochemical research, little in the way of directed fuel cell R\&D is being presently supported within these automotive companies.

However, there was evidenced a sustained interest in the potential of the fuel cell for transportation, as well as a history of nominal involvement in fuel cell research and development extending back to about the mid-1960's. Ford mentioned its support of a multi-sponsor activity in transportation fuel cell systems carried out in the mid-tolate 1960's by Battelle Columbus Laboratories. General Motor's "Electrovan" project, a hydrogen-oxygen alkaline electrolyte fuel cell powered expermental vehicle, dates back to the same time period. However, current or recently carried out work in transportation fuel cells, other than for the purpose of "maintaining awareness," was not evidenced at pither Fnrd nr GM

The attitude taken by our bringing the subject of fuel cell/battery propulaion syctcme up before thece automotive oontaote was of the nature 
of a question:

"What is there, new and different, about this concept which would make it worth pursuing?"

However, it also became clear that fuel cells were viewed as "further advanced" elements in the general context of electric vehicle systems for which the two companies have substantial activities in progress.

Although no concerted attempt was made to respond to this question, specific areas of automotive industry concern as to the implied drawback of fuel cells in an overall context of alternative vehicle propulsion systems were asked about. Both general and specific comments are summarized below:

Although evidently committed to carrying out electric vehicle research, the basic thesis that this approach should be a preferred one for reducing automotive petroleum use appeared not generally accepted. One comment was that an equivalent effort to changeover electrical generating plants from oil to coal would be far more effective in pursuing this aim.

Technically, electric vehicles of any kind (fuel cell systems included) are much more massive systems than those in use today. With major efforts of the industry being focused on weight reduction programs and vehicle down-sizing, electric vehicles "buck the accepted trend." ("Vehicle energy use is almost directly a function of weight at the wheel in residential and metropolitan driving.") The obvious (but unanswered) question then, is : What weight-reduction leverage would introduction of the fuel cell provide to electric vehicles?

On a positive note, based upon one representative's 16 years of direct experience in electric vehicle activities, it was projected that the "frustrations" of the all-battery approach would likely engender renewed interest in the fuel cell. Not-so-positive was his follow-up point that only more frustrations, not success, with the fuel cell would result from such renewed interest. 
More broadly, it was sensed that the automotive people increasingly perceive the main thrust for solving the problems attendant to transportation dependency on oil (especially imported oil) to be the development of alternative sources of conventional finished fuels usable in conventional cars, from domestic coal and oil shale.

With respect to the two fuel forms being addressed in this assessment - methanol and hydrogen - industry contacts indicated that methanol was a much more credible alternative. Although concern was expressed over the implied methanol production and delivery requirements of largescale vehicle use, the equivalent needs for hydrogen were seen as a much touqher challenge.

Also, whereas onboard storage system and vehicle fueling requirements for. methanol were preceived as reasonable extensions of the present liquid fuels state-of-the-art, those for hydrogen would be more difficult to meet. However, it was not clear that the industry people were necessarily aware of recent advances in metal hydride or cryogenic liquid onboard containment technology and fueling techniques.

One automotive company (Ford) had recently initiated a one-year comprehensive in-house survey and assessment of hydrogen as a future automotive energy torm, but no conclusions are yet avallable.

A specific concern is that of the problem of supply for noble metal catalysts as required in (some) * fuel cells. It was noted that where about 2 to 4 grams of platinum catalyṣt per vehicle are used in catalytic converters, the order of 30 grams per vehicle have been estimated for a typical vehicle fuel cell installation. Apparently, cost is less of a concern than the feasibility and reliability of expanded supplies of platinum group metals from south Africa and the Soviet Union (which supply about $70 \%$ of current U.S. demand. ${ }^{1}$ )

* Alkaline fuel cells, specifically, do not require noble metal catalysts. 
Technically, and within the electric vehicle context, the automotive contacts uniformly tended to regard the fuel cell as an "energy battery" which could match and complement the "power battery." Both Ford and GM noted the established "hybrid battery/battery" system concept as an analog to the proposed fuel cell/battery system.

\section{Discussion of Government and National Laboratory Contacts}

As an overview, current Government programs supporting fuel cells are only minimally directed to surface transportation applications. There are exceptions to this, such as the U.S. Army MERADCOM efforts on forklift trucks and similar applications and modest efforts at BNL and LASL to be discussed (supported by DOE). This cooperative work is reflected in a jointly authored technical presentation. ${ }^{2}$

The major Government-supported programs are the following:

1. DOE's electric utiity fuel cells power plants program focusing on the 5-MW class and larger of phosphoric acid (first generation) and molten carbonate (second generation) system.applications based on hydrocarbon fuels.

2. NASA's spacecraft power system programs which include alkaline and solid polymer electrolyte fuel cells development for the space Shuttle and advanced space applications based upon hydrogenoxygen reactants.

3. DOD's ground-based aircraft and spacecraft power system programs which parallel NASA's to some extent, but which include phosphoric acid electrolyte fuel cell developments under the Army (MERADCOM) for limited transportation applications (to be discussed in detail below).

4. Several of the national laboratories, carrying out DOE-sponsored activities, have expressed interest in fuel cells for transportation applications. In several cases, efforts are underway in applications stuales and in research, development, and demonstration:

- Through its Energy storage and Conversion Division, BNL initiated a program entitled, "Development of Fuel Cell Technology for Vehicular Applications," in Fiscal Year 1978, The initial year's work, in collaboration with LASL and MERADCOM, included a survey of the fuel cell and battery stateof-the-art. Small-scale experiments with three types of fuel cells were carried out: phosphoric acid electrolyte, solid polymer electrolyte, and alkaiine $(\mathrm{KOH})$ electrolyte units. ${ }^{3}$ 
- BNL is also cooperatively supporting an experimental forklift truck demonstration to be assembled and evaluated at MERADCOM. The specific subsystem activity being funded by BNL is an onboard iron-titanium metal hydride hydrogen supply unit being prepared by Billings Energy Corporation.

- LASL has developed, and is exercising, a computer simulation capability for fuel cell/battery powered vehicles which encompasses specific hardware descriptions to the component level. Once "designed," these vehicles can be operated over stipulated driving cycles and the fuel cell and battery outputs monitored in detail at any point during the simulated driving cycles, e.g., wide-open throttle, SAE J227 standard residential and municipal driving cycles.

- LASL has also assembled arl experimental fuel cell/battery vẹhiçle syṣtem based upon a golf cart. This engineering test. and evaluation unit uses an Eneryy Researeh Corporation (ERC) fuel cell and conventional golf cart batteriés. Hydrogen fuel is carried as pressurized gas in a set of SCUBA tanks. Initial operation of this test vehiele was reported to have been aooonplished in late september 1979.

- Related to its continuing multi-year assessment of "Energy Storage Systems for Automobile Propulsion," 4 the LLL is reported to be examining the fuel cell/battery power system using its computer analysis capabilities. ${ }^{5}$ However, it is significant to note that fuel cell systems have not been included in the published LLL study reports to date. (S $\overline{\text { See }}$ footnote, p. 4-13.)

- Argonne National Laboratory (ANL), which carries "leadlaboratory" responsibility for vehicle electric storage battery systems, is active in transportation battery research and development for DOE. A recent review of progress in the overall DOE program in this field was provided by Katz and Klunder. 6

'I'o date, the only Goveriment-spunsured ellus liuled lu liave resulted in the actual construction and test of an operating fuel cell/battery vehicle system is that of the U.S. Army's MERADCOM, as reported by Dowgaiallo and his colleagues. 7,8 *

Four 1-kW phosphoric acid electrolyte fuel cells were connected in parallel and operated using hydrogen gas from four standard pressurized gas cylinders aboard the vehicle. MERADCOM is developing a methanol steam reformer to replace the cylinders in the future. " The fuel cell

* To which could now be added the above-mentioned fuel cell/battery golf-cart-based engineering test unit of LASL. 
stacks were derived using Engelhard Industries 750-watt stacks, to which additional cells were added to uprate these to $1 \mathrm{~kW}$. Each stack is rated at 42 volts.

The battery complement consisted of 6 standard automobile starting/ lighting batteries (Sears "Diehardtm" units, rated at 96 amp-hours at the 20-hour discharge rate). These were connected in two paralled branches of 3 batteries in series.

Load profiles for equivalent lift-truck operations were acquired in a special measuring program conducted by MERADCOM using a conventional 4000-pound capacity all-battery powered vehicle. In laboratory tests, using the derived load profiles, the fuel cell/battery powered forklift truck operated well over a 3-year period. The fuel cells have experienced over 250 hours of operation and 54 thermal (on/off) cycles. MERADCOM believes that the fuel cell/battery approach would greatly extend the range and performance of present battery-powered vehicles, and that other vehicles could be fitted with these power systems.

References Cited in section 4-B

1. Anon.., Business Week, 59, (1979) October 8.

2. McCormick, B., et al., "Applications of Fuel Cells in Transportation," combined LASL, Energy Reserach Group, Inc., BNL, and MERADCOM presentation at the 14th Intersociety Energy Conversion Engineering Conference, Boston, August 5-10, 1979.

3. McBreen, J., et al., "Development of Fuel Cell Technology for Vehicular. Applications," Brookhaven National Laboratory, Annual Report for Fiscal Year 1978, November 1978.

4. Behrin, E., et al., "Energy storage systems for Automobile Fro.

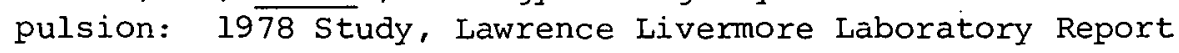
UCRL-52553 (2 volumes), December 15, 1978.

5. Personal communication from G. Strickland of BNL, September 1979.

6. Katz, M.J., and Klunder, K.W., "The Department of Energy Electric Vohicle Battery Program, $h$ n Ovcrvicw," DOE prosontation at the 14th Intersociety Energy Conversion Engineering Conference, Boston, August. $5-1.0,1979$. 
7. O'Sullivan, J.B., Dowgiallo, E.J., and Snellings, I.R., "Hybrid Power Source for Material Handling Equipment," MERADCOM presentation at the loth Intersociety Energy Conversion Engineering Conference, Newark, Delaware, August 18-22, 1975 :

8. Dowgiallo, E.J., "A Fuel Cell-Battery Power Source for Electric Vehicles," MERADCOM presentation at the Fifth International Electric Vehicle Symposium, Philadelphia, October 2-5, 1978.

SPECIAL NOTE REGARDING EFFORTS UNDERWAY IN THE JOINT DUTCH/BELGIUM EFFORT BY ELENCO (and by Siemens AG in West Germany)

"In Europe, work continues on alkaline fuel cells for terrestrial applications. At the Electrochemistry Laboratory of Siemens in Erlangen, West Germany, 3.5 and $7 \mathrm{~kW}$ alkaline hydrogen/oxygen fuel cells have been built and tested. A program is now underway to construct a $20 \mathrm{~kW}$ unit (14). These units are being considered for standby applications, for example, in hospitals. 'l'he $7 \mathrm{~kW}$ unit which was completed in May, 1978 cons1sts of a fuel cell stack and electrolyte regeneration for product water removal. The cell stack consists of 70 cells and it delivers $142 \mathrm{~A}(420 \mathrm{~mA} / \mathrm{cm})$ at $53.8 \mathrm{~V}$. The electrocatalysts for the anode and cathode are Raney nickel and doped silver respectively. The system weight is $85 \mathrm{~kg}$ and the volume 60 l. The unit reaches $45 \%$ of rated power at $20^{\circ} \mathrm{C}$ and reaches the desired operating temperature of $80^{\circ} \mathrm{C}$ in eight minutes."

"In 1974, ELENCO, an organization consisting of three partners: the Study Center for Nuclear Energy (SCK/CEN), Mol, Belgium; Dutch State Mines, Geleen, Netherlands; and Bekaert, Brussels, Belgium was formed with the aim of developing alkaline fuel cells particularly for transportation (15). Work to date has involved the design, fabrication and testing of a $10 \mathrm{~kW}$ fuel cell. The $10 \mathrm{~kW}$ system consists of three $36 \mathrm{~V}$ module stacks in series. Each module stack consists of six $6 \mathrm{~V}$ modules. Each module consists of $18 \mathrm{cell}_{\mathfrak{Z}}$ in a series-parallel. The active electrode area in the cells is $300 \mathrm{~cm}$. The present design point is $80 \mathrm{~mA} / \mathrm{cm}^{2}$ at $0.67 \mathrm{~V}$ per cell. ELENCO has also carried out technoeconomic assessments. The main applications considered are for use of hydrogen byproduct gas from the chloralkali industry and as power sources for buses, fork lift trucks and special purpose vehicles."

"The ELENCO program is being funded at a $\$ 5$ million dollar level for the first three years which ends in December, 1978. The program has been renewed for a second three-year term at a $\$ 7$ million dollar level. In the second period stress will be on improvements in power densities by about $50 \%$ and continuation of the systems studies to explore further applications."

Source: McBreen, J, et al., "Development of Fuel Cell Technology for Vehicular Applications," Brookhaven National Laboratory, Report FCT-1, May 1979. 
Table 4-1. PRINCIPAL CONTACTS MADE BY ASSESSMENT TEAM (Note: Individual Contact/Visit Memoranda for Each Contact Listed are Provided in Exhibit A of the Study Report)

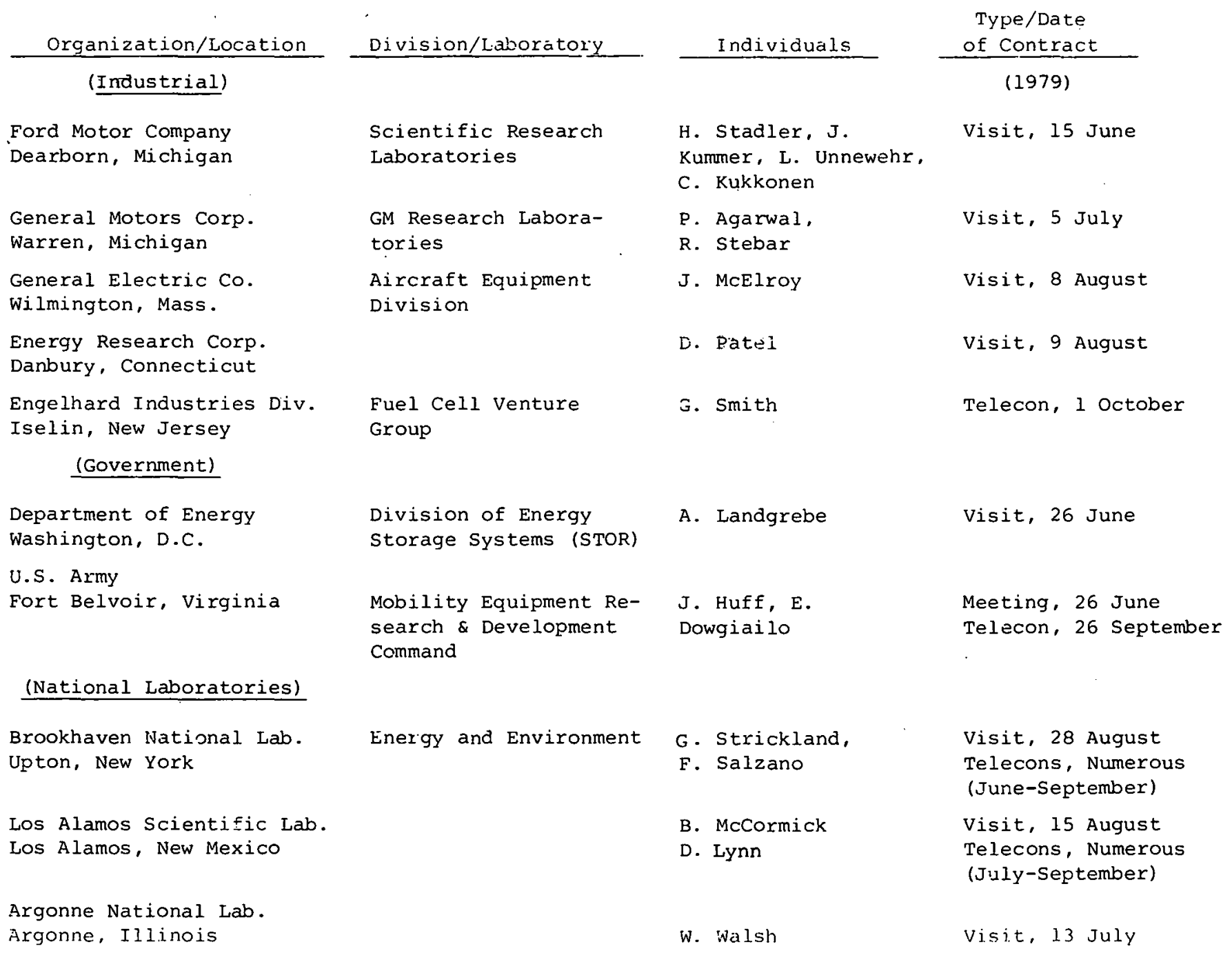


C. RD\&D NEEDS AND OPPORTUNITIES

Objective of the Task

In Task 3, the Assessment Team attempted to develop a basic RD\&D approach which would be most appropxiate for forwarding transportation fuel cell technology from its current state, specifically to advance fuel cell/battery power systems toward a potential marketentry point.

The task objective was -

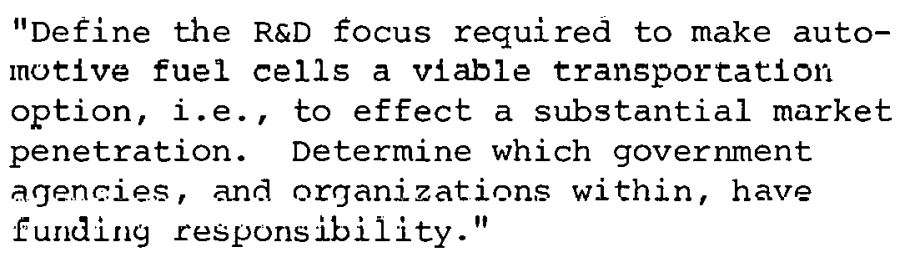

Approach

This task effort proceeded along two paths: 1) an evaluation of transportation fuel cell and battery technological and programmatic status, as derived from the preceding two task activities reported above, and 2) to develop a framework in which to view the fuel cell/battery power system concept as it might progress through the research, development, and demonstration phases and address the market-penetration opportunity, when and if this stage is reached.

Theee two arcac are bricfly dicoucced bclow. However, the specific observations, conclusion, and recommendations deriving, in part, from this task have been documented earlier in section 2 .

\section{Technical and Program Status}

As pointed out in the discussion of the technical literature and current contacts (Sections $4 \mathrm{~A}$ and $\mathrm{B}$ ), emphasis to date in fuel cell work has been other than transportation power systems oriented. Therefore, fuel cell powered vehicle efforts are limited, and more so, fuel cell/battery vehicle projects. 
On the other hand, all-battery electric vehicle research, development, and demonstration work has been pursued actively over the years. Work has been considerably augmented in the United states in the past few years as a consequence of the previously mentioned Public Law No. 94-413 legislation stimulating an aggressive RD\&D program.

In terms of the conventional progression of a technology from the research stage to the commercialization stage, Figure 4-1 attempts to roughly portray the status of the transportation battery, fuel cell, and fuel cell/battery technologies.

Heywood and Linden have provided a specific model of the 20-30. year Iife-cycle of automotive systems which is diagrammed in Figure 4-2. 1 This presentation can be taken to be generally applicable to all transportation systems which might employ fuel cell/battery power systems.

In relating Figures $4:-1$ and $4-2$, it can be noted that the demonstration phases of the former are merged into the development and introduction stages of the latter. Respectively, commercialization is implicit in the introduction, mass production, and fleet turnover stages.

In review, fuel cell/battery power systems work is presently at the applied research stage and, therefore, the full RD\&D cycle must be undertaken to achieve a market-entry or onset-of-commercialization stage.

RD\&D Needs and Opportunities

Figure 4-3 provides a graphical basis for considering the general direction which research, development, and demonstration efforts for fuel cell/battery powered transportation systems might proceed in relationship Lu uller programs.

Along the top horizontal line-of-progression is shown the in-being all-battery vehicle RD\&D efforts stimulated and focused under DOE's implementation of Public Law No. 94-413 (hybrid activity not shown). To the extent which high power output battery and other component t.erhnology is being advanced, and products are being developed, this effort is directly supportive of the fuel cell/battery power system concept. 


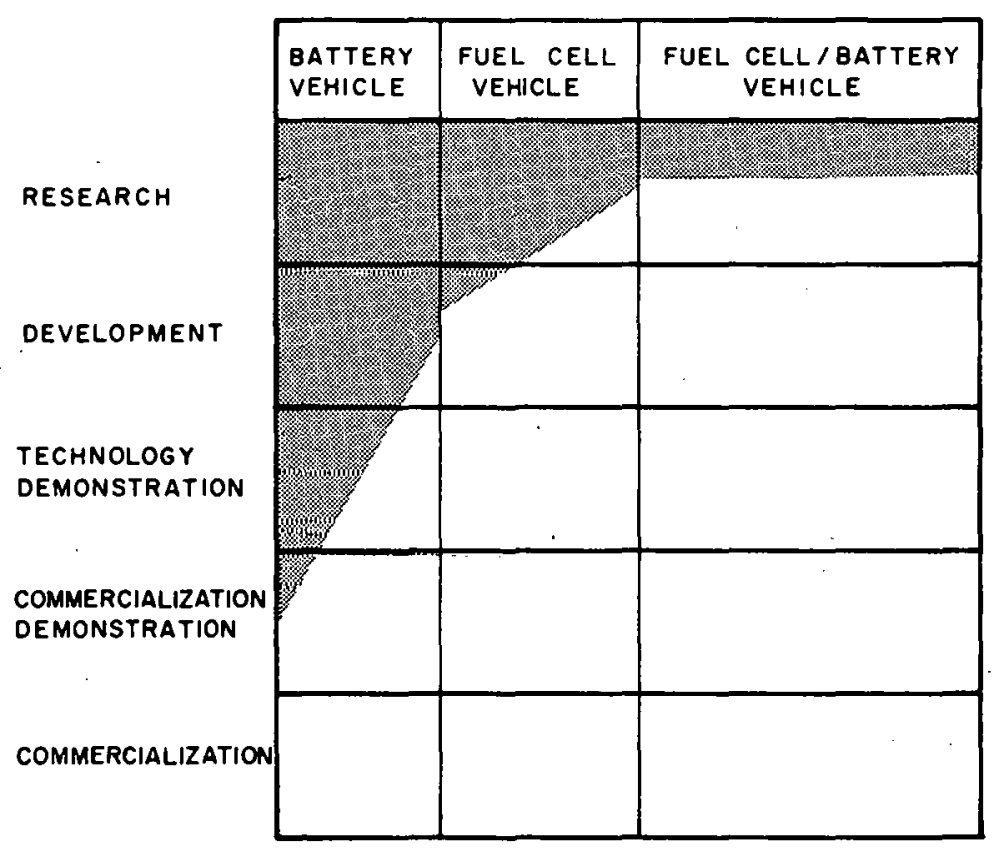

A-1978-10-031

Figure 4-1, Status of the Transportation Battery, Fuel Ce11, and Fuel Cell/Batteries Technologies

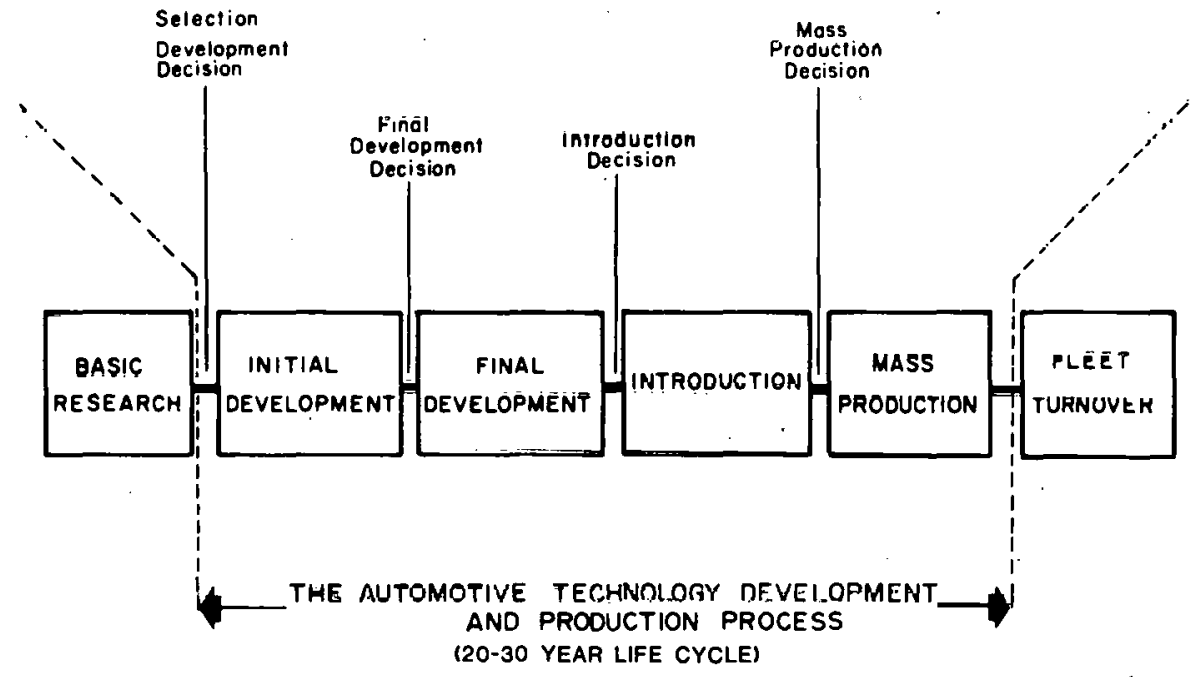

Figure 4-2. A Simplified Model of the Stages and Decisions in the Process of Automotive Technology Development and $\overrightarrow{\mathrm{P}}$ roduction 


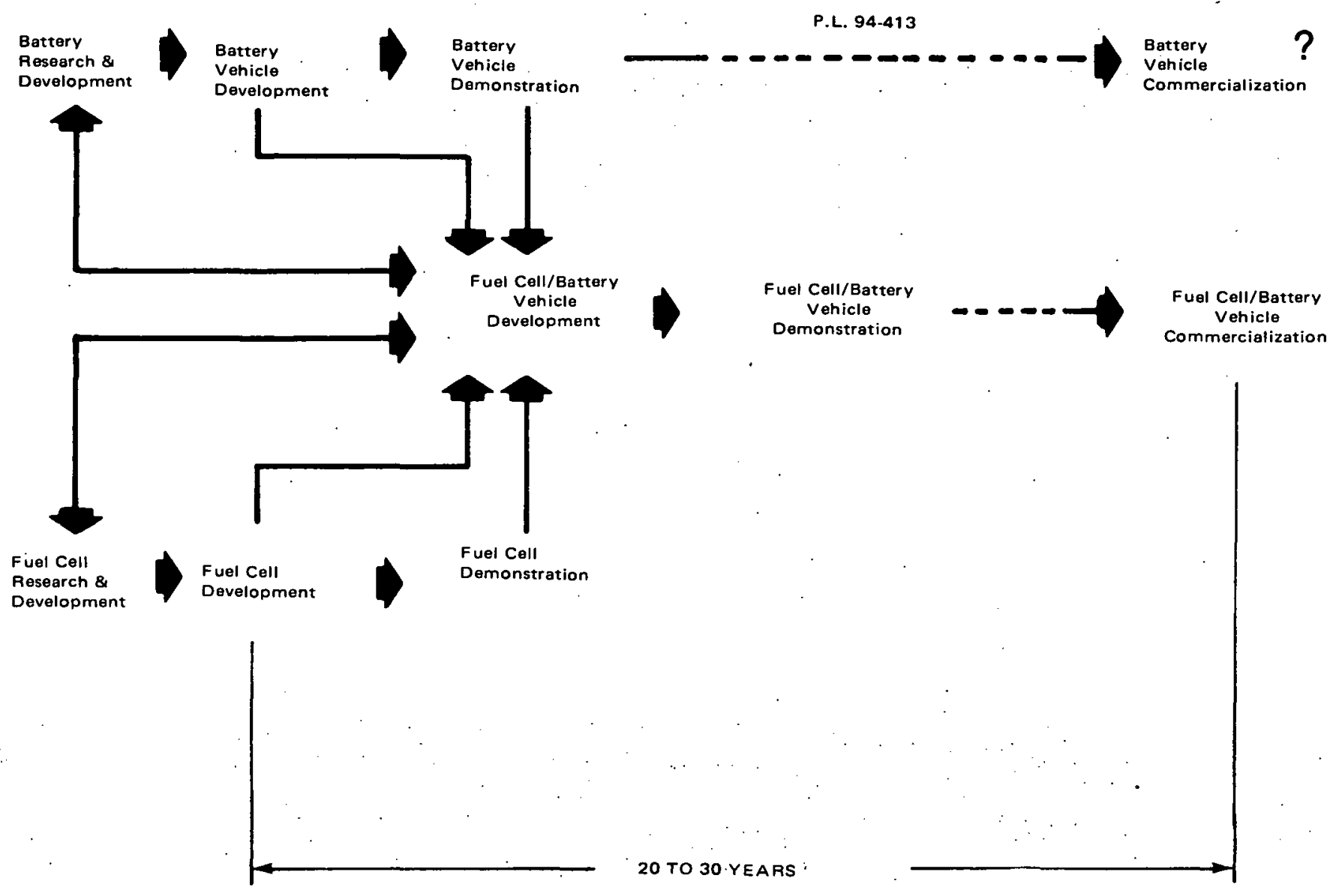

Figure 4-3. Suggested Interrelationships Between the Three Design Concepts Assuming the Fue1 Cell/Battery Designs Were to be Further Pursued. 
Along the lower "fuel cell" line-of-progression, other than transportation applications are being presently addressed. Nevertheless, some substantial share of the associated technology advances are applicable to transportation fuel cells. In other words, potential technical and cost benefits are being accrued.

Thus, both the battery (upper) and fuel cell (lower) RD\&D activities indirectly are supportive of a projected fuel cell/battery vehicle development and demonstration effort (middle line of progression). such an effort does not exist at this time.

Although distinct development and demonstration stages will be required and are shown in the figure for the Euel cell/battery system, no special or dedicated research phase is indicated. This is because, if effective feedback can be maintained from the development effurt, the existing battery and fuel cell research activities, and the supporting infrastructure, should be reasonably capable of supporting and completing the concept's research needs as these become apparent.

Going forward in time from the development stage, an ultimate market-entry and initial commercialization step is suggested for the fuel cell/battery vehicle system effort, provided the demonstrationstage results are sufficiently positive. As noted in section $2 c^{\circ}$ (Recommendations), this stage must be resolutely directed to the minimization and elimination of uncertainties of several types, such that commercial decision-making processes can operate erfectively and that a sistaliea market penetration can be accomplished.

Regarding special opportunities which can be potentially addressed by the fuel cell/battery program element activity, were this to develop, perhaps the most impacting of these from today's vantage point is that of expanding the applicability of electric vehicle systems to new uses, previously viewed as beyond the "technological reach" of electric systems, and specifically all-battery systems.

However, a specific discussion of these possibilities is relegated to later Appendix $C$. The reader is referred to this discussion. 
D. RELATIONSHIPS : BATTERY (ONLY) AND FUEL CELL/BATTERY VEHICLE

POWER SYSTEMS

Objective of Task

Task 4 of the asssessment considers the fuel cell/battery approach in context with electric vehicle system research, development, demonstration, and commercialization activity:

"Evaluate the relationship between batterydriven and fuel-cell/battery driven vehicles, i.e., common technical problems and system components, as well as the respective advantages. Discuss how fuel-cell-driven vehicles might be affected in the market place due to the presence of battery-driven vehicles."

\section{Approach}

The information gathered in the literature search and those 1 direct contacts already discussed, plus applicable in-hand background, were drawn upon in the discussion to follow.

\section{General Relationships}

On a technical basis, the fuel cell/battery power system vehicle concept fits in as a subset under the general category of "electric vehicles." In context with all-battery power systems, as currently stressed in the U.S.'s Electric and Hybrid Vehicle Research, Development, and Demonstration Act, program commonality of systems, subsystems, and components is expected to be much more the rule than the exception. Thus, there is a very strong "family relationship" apparent between the all-battery and the fuel cell/battery vehicle power systems approaches.

Further, several contacts in the fuel cell industry advised the assessment team to maintain comparisons of fuel cell vehicles with other electric vehicles. Comparisons to conventional internal combustion engine powered systems should be used with considerable caution. 
This relationship can be illustrated with hybrid battery/battery (all-battery) power system discussed in section 4A (GE and Yardney). The fuel cell as an "energy battery," limited in capacity only by fuel system capacity, would fit into the battery/battery system approach with no disruption or compromise to the hybrid concept previously discussed.

Rather, and this is seen as the basic "theme" of fuel cell/ battery system proponency, integration of the fuel cell "energy battery" markedly improves the capability of the electric vehicle, e.g., provides needed range and dndurance extension vis-a-vis all-battery systems.

Vohiale aomponents under development for all-batterg oysteme controllers, instrumentation, motors, wiring and connectors, special ancillaries, and auxiliaries - will continue to be appliaable to fucl cell/battery power systems. Thus, the integration of fuel cell subsystems into present (but suitably modified) electric vehicles seemingly could proceed without major new component development programs.

It would appear practical and desirable to use existing and service-proved electric vehicles for basic reliability purposes. NASA has observed in their recent state-of-the-art road-test assessment of all-battery. vehicles: ${ }^{1}$

"The reliability of the electric vehicles tested was poor compared to convontional vohicloc. As there are presently electric vehicles in service that have demonstrated very high reliability, it is expected that as the industry matures the reliability of all electric vehicles will improve."

It can be thus inferred that any new-irom the "wheels "up vehicle specially developed for fuel cell/battery power systems evaluation would also tend to suffer from unrealibility initially.

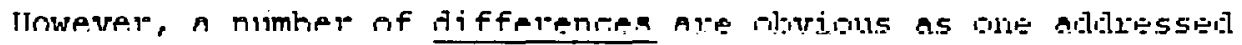
the fuel cell/battery approach in the context of all-battexy vehicle systems. Key among these are - 
a. Fuel cell/battery vehicles require supplies of chemical fuels (methanol and hydrogen are emphasized in this study), and would not be directly charged from the utility electric grid.

b. Battery technical requirements as applied to a "power battery" to be integrated with a fuel cell subsystem are likely to be different than heretofore applied (except as already examined in the hybrid battery/battery approach).

c. In at least some fuel cell subsystems, reject heat will be available for uses such as vehicle passenger compartment heating (a problem area in all-battery systems).

d. Vehicle unrefueled range and endurance capabilities, as indicated by preliminary driving cycle simulation runs (see section $4 \mathrm{~F}$ ) can be equivalent to, and even superior to, conventional gasoline and diesel fuel vehicles, which is not the case with all-battery vehicles to date. (It is not yet clear that on-the-road performance:acceleration, hill-climbing, etc., can approach that of conventional vehicles, however.)

The above discussion suggests incentives for an examination of the fuel cell/battery approach. This would seem fully appropiriate within the context of the ongoing electric and hybrid vehicles RD\&D effort.

One major ramification external to the vehicle system is clear: A shift is indicated in basic energy supply, to be further discussed.

The Issue of Energy Supply

Fuel cells require a chemical fuel by nature. In the fuel cell/ battery concept, the battery is recharged by the fuel cell; an electrical energy supply is not required. Such supply is required by the allbattery vehicle. Thus, electric utilities are found to be basic participants in the present electric vehicle program.

Fuel cell/battery vehicles might still be supplied energy from the clcctric utilities, however.* Based upon a conversion of electricity to hydrogen via water electrolysis, at or near the vehicle fueling point,

The obvious alternative is supplying fuels in a mode analogous to the case of conventional vehicles. With methanol and hydrogen being "alternative fuels," activities under the existing DOE Alternative Fuels Utilization Program ${ }^{2}$ are pertinent. 
fuel cell/battery vehicles could be thus serviced by means of "hydrogenvia-electricity." such a concept has been published, ${ }^{3}$ and discussions with selected utilities carried out. ${ }^{4}$ Generally, the scheme appears practical. The key issue, as yet not addressed, is the resulting cost of hydrogen "at the pump."

It may also be practical to provide methanol from electrolytic hydrogen. This would require a source of feedstock $\mathrm{Co}$ or $\mathrm{CO}_{2}$, and an appropriate methanol synthesis facility. With electrolytic oxygen available as an off-setting byproduct, possibilities occur for synergistically integrating the methanol production facility with another industrial process requiring oxygen and giving off carbon dioxide.

Such a "methanol by wire" approach is quite analagous to the "ammonia by wire" concept which has been under consideration over the years. Obviously, the basic approach is not restricted to fuel cell/battery vehicle fuel supply applications.

An interesting alternative to electric utility supplied hydrogenvia-electricity, one that focuses on the sun as a renewable energy, is solar/hydrogen. A current study of this approach has indicated that several specific systems might be commercializable within the 1980-2000 time period: 5 Technologies involved are thermal heat engines, photovoltaics, wind energy, and small hydropower.

A recent general review of hydrogen production and delivery means, oriented to automotive usage, has been published by the Aerospace Corporation. 6 This and the general literature now available on hydrogen energy systems can be consulted for background.

Finally, as required in the present assessment task statement, the current views and outlooks of DOE and several industrial organizations on coal-based hydrogen and methanol are summarized in section $4 \mathrm{E}$. 


\section{Possible Market Place Interactions}

The subject of market place interactions between all-battery electric vehicles, which are assumed to have substantial penetration, and fuel cell/battery vehicles, as these are to be introduced, is highly speculative at this point in time. In the first place, it is far from clear what facets of the transporatation sector will in fiact have batteryvehicle service in the decades ahead.

As evidenced in the enactment of Public Law No. 94-413, and its administration to date, it is clear that Government-stipulated actions may have a strong influence on battery-vehicle initial penetrations. Clean-air incentives, for example, could press electric vehicles into city-center service more aggressively than would otherwise happen strictly through "market pull" incentives.

If it is asssumed that a substantial battery-electric market penetration has occurred, what then would be some of the considerations as fuel cell/battery systems reached market-introduction status? Here are some of the issues:

1. Electrical charging stations established for the battery-electrics would not be directly usable by fuel cell/battery vehicles (as discussed earlier).

2. Provided component commonality. were to be widely achieved, the fuel cell/battery vehicles would provide a broader market to further support all-battery systems parts and service systems. This expansion of needs could provide the manufacturing and service industries wi.th "new business" incentives.

3. Electric vehicle operators would be able to extend their operations, in certain cases, through the augmented capabilities of fuel cell/ battery systems, and would expand their fleets and/or achieve an optimal mix of all-battery and fuel cell/battery vehicles.

4. With reference to the above point, it is not possible to state whether a balanced fleet mix would, in fact, be achieved in the long run. Alternatively, the fuel cell/battery systems might totally displace the all-battery systems except where the latter retain unique advantages, e.g., the requirement of operating direct.ly from the electrical grid.

5. As for the battery manufacturing and service industry which is. a key compunent of all-batlery systems, the degree of dependence 
on this industry for fuel cell/battery systems will be considerably less. Batteries conprise both a much lesser fraction of the vehicle overall power system complement in the fuel cell/battery case and should pose somewhat of a lesser technical challenge as well.

6. In comparison with the battery manufacturing and servicing industries, there is today no equivalent fuel cell industry. Within the industrial fuel cell organizations which are today involved in research and development activities, the great proportion of work going on is directed to other than transpurtation power system applications. If fuel cells are to ever enter the market place, an appropriate industrial base must be developed ahead of time.

Clearly, more attention must be given to llie issue of all-battery

vs. fuel cell/battery interactions in the market place. However, until clear trends emerge with regard to 1$)$ the technical and commercialization success of fuel cell/battery systems, on the one hand, and 2) the anticipated market penetration of all-battery systems, on the other, assessments of this issue will remain speculative.

A step which might be fruitful, in examining such interactions, would be directed to the research, development, and demonstration operation of fuel cell/battery vehicles in direct comparison to all battery vehicles emerging from Public Law No. 94-413 supported programs. References Cited in Section 4D

1. Dustin, M.O., and Denington, R.J., "Test and Evaluation of 23 Electric Vehicles for State-of-the-Art Assessment," NASA Lewis Research Center presentation, SAE Technical Paper No. 780290, 1978.

2. Anon., "Project Planning Document Highway Vehicle Alternative Fuels Utilization Program (AFUP)," Department of Energy Report DOE/ CS-0093, July 1.979.

3. Escher, W.J.D., "Hydrogen-via-Electricity, A Candidate Transitional Transportation Energy System Concept," Report ERDA 77-13 (TEC 77/001), September 1976.

4. Escher, W.J.D., "Survey of Electric Utilities Views on the Hydrogenvia...Electricity Concept," Repurt for the vepartment of Energy CONS-2752-02 (limited distribution). 
5. Escher, W.J.D., Foster, R.W., and Hanson, J.A., "Assessment of Solar/Hydrogen Systems." Paper presented at the DOE Contractor's Meeting, Reston, Virginia, October 1979.

6. Donnelly, J.J., Jr., et al., "Study of Hydrogen-Powered Versus Battery-Powered Automobiles," Aerospace Corporation Report No. ATR-79(7759)-1, (3 Volumes), May 1979.

7. Esposito, E.J., "Overview of Electric Vehicles in the United States," Department of Energy presentation, SAE Technical Paper No. $780085,1978$. 


\section{E. OUTLOOK FOR FUTURE AVAILABILITY OF HYDROGEN AND MFTHANOL FROM COAL}

\section{Objective of Task}

Under Task 5 of the assessment, the general issue of future fuel supply for both hydrogen- and methanol-using fuel cell/battery powered vehicles was addressed. Focus was on coal as the primary energy resource for the production of these fuels. The specific task statement was:

"Obtain current views and outlook of DOE and industrial organizations regarding the future availability of hydrogen and methanol derived from coal."

Approach

Diroot tolophonc contacto vere made with iepiesenlalives LI LUE and also in industrial and fuels research organizations involved in coal-based hydrogen and methanol production processes. In these contacts, emphasis was placed on soliciting candid views and outlooks for establishing an adequate supply of coal-based fuels, eventually capable of fueling substantial fleets of fuel cell/battery vehicles, assuming the latter's success in the market place.

Those organizations contacted included -

- DOE's Office of Fossil Energy

- DOE's Officc of Tranaportation Frograms

- Tennessee Valley Authority

- Institute of Gas l'echnology

- Exxon Research and Engineering Company

- Chem Systems, Inr.

No comprehensive review of the literature was pursued. However, some pertinent references were consulted as listed at the end of the section. 
General Findings: Methanol and Hydrogen Industrial Practice and Prospects for Coal Use

The prospects for coal-derived hydrogen and methanol being available in the market place for transportation fuel applications depends upon both the market demand and the coal supply. At the present time, coal availability is good due to excess mining capacity, but the hydrogen and methanol markets are too small to support coal conversion plants. In the not-to-distant future, this condition may be reversed as the synthetic fuel industry develops (i.e., synthetic crude, SNG, methanol, and hydrogen from coal) and competes with the electric utilities for the available coal.

Almost all of the methanol and industrial hydrogen produced in the United States today is manufactured via catalytic steam reforming of natural gas and, to a lesser extent, other light hydrocarbons. ${ }^{1}$ Plant sizes for hydrogen production as represented by those located at U.S. refineries average about $50 \times 10^{6} \mathrm{Btu}\left(16.3 \times 10^{9} \mathrm{Btu} /\right.$ day $)$ of product gas per day. The largest plants are nominally $100 \times 10^{6} \mathrm{SCF} /$ day $(32.5 \mathrm{x}$ $10^{9}$ Btu/day). 2 Methanol plants are similarly sized, with the largest current plant producing up to 2000 short tons/day $\left(39 \times 10^{9} \mathrm{Btu} /\right.$ day $) .^{3}$

Plants for producing hydrogen and methanol from coal are now being considered at the $1000 \times 10^{6} \mathrm{SCF} /$ day and 2000 short tons/day size. However, prior to about 1977, most published data referred to planned plants having output capacities of about $250 \times 10^{9} \mathrm{SCF} /$ day. It is these large multi-train plants that take advantage of substantially larger plant scale which promises the most attractive synfuel costs. However, these large plants are clearly luo hig for the current hydrogen and methannl requirements. At the 1975 hydrogen requirement (excluding methanol requirements) level of about 0.52 quad/year 4 (Table 4-2), only about six large coal-to-hydrogen plants would be required, and for the 1976 methanol demand level of $3.1 \times 10^{6}$ tons, ${ }^{5}$ only one large coal-to-methanol plant would be needed. (By "large" is meant $250 \times 10^{9}$ Btu/day.) Thus, the total 
current hydrogen and methanol market could be served with about 7 coal conversion plants, provided a system for product distribution existed.

Table 4-2.. 1975 U.S. HYDROGEN REQUIREMENTS ${ }^{2}$

\begin{tabular}{lc} 
& quad/year $\mathrm{H}_{2}$ \\
\cline { 2 - 2 } Refining Hydrogen & 0.15 \\
Ammonia & 0.35 \\
Methanol & 0.06 \\
Small User Hydrngen & $\underline{0.02}$ \\
$\quad$ Total & 0.58
\end{tabular}

* One quad/year equals $10^{15}$ Btu/year. Overall U.S. energy consumption in 1978 was about 78 quads/year. (Source IGT GaScope, Spring 1978).

Since the Inarket for large coal conversion plants has not yet developed, with the synfuel industry still "on the drawing boards," the smaller plants (a size preveiously considered as "demonstration") are now being considered for use in the existing market. Based on the results of economic studies recently reported, 6,7 the prospects of "small" coal conversion plants being built looks promising. Figures 4-4 and 4-5 show the results of one such economic study, ${ }^{6}$ A $100 \times 10^{6}$ sr.F./A. plant would be equivalent to $32.5 \times 10^{9}$ BLu/day (Higher hearing válue [HHV] basis), or about one-tenth the "large" plant mentioned earlier. As can be seen, methanol from coal appears to be attractive when compared with either natural gas steam reforming or partial oxidation of residual fuel oil. Hydrogen from coal, on the other hand, appears somewhat less rompetitive with existing supply technologies for the near term.

A special "Hydrogen. From Coal Cost Estimation Seminar" was carried out under the sponsorship of the DOE and administered hy the Rillings 

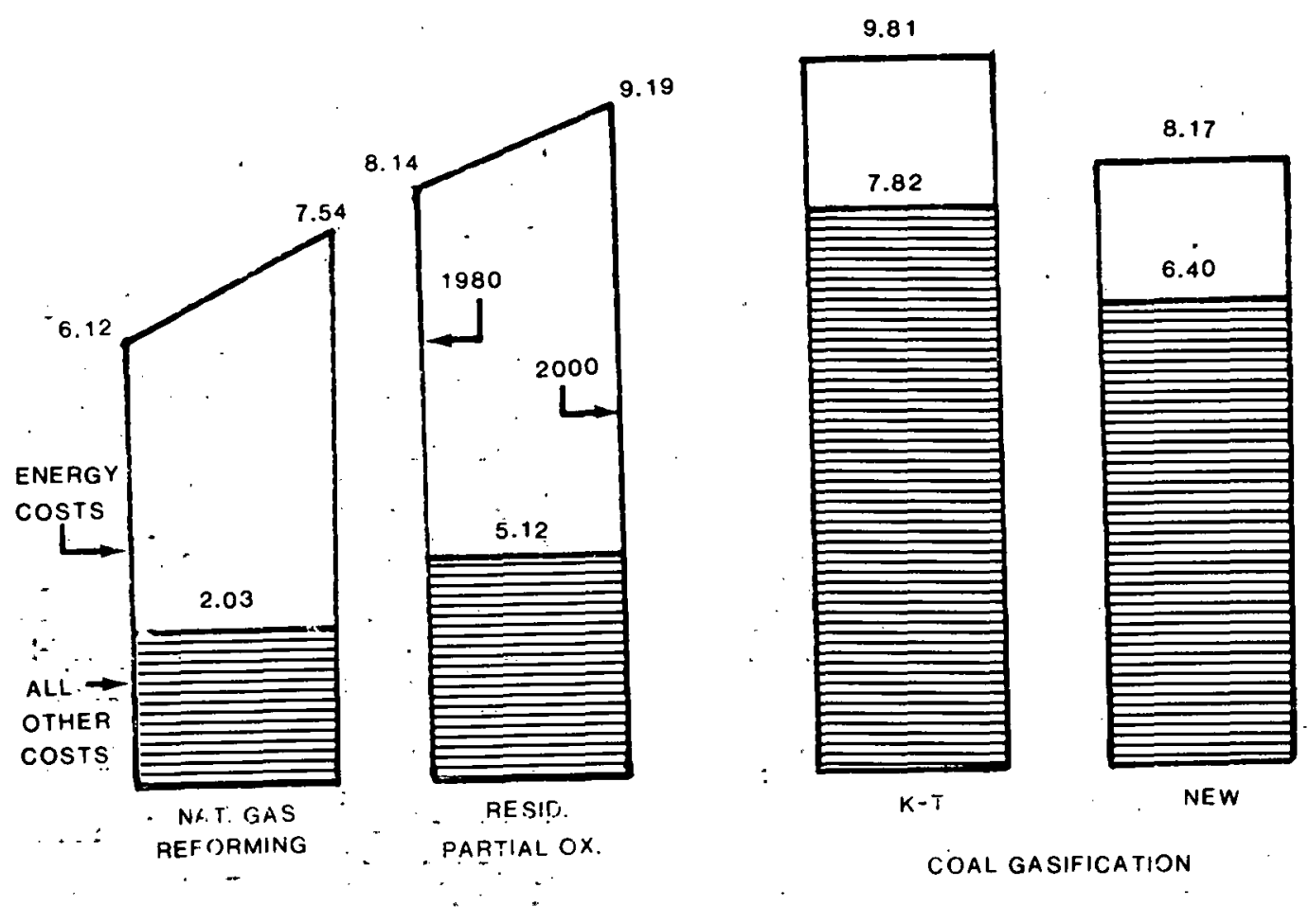

A-1979-12-057

Figure 4-4. Hydrogen Manufacturing Costs - Midcontinent Location 6 $\left(\$ / 10^{6}\right.$ Rt.u for $100 \times 10^{6}$ SCF/day Plants, $\left.1980 \$\right)$ 


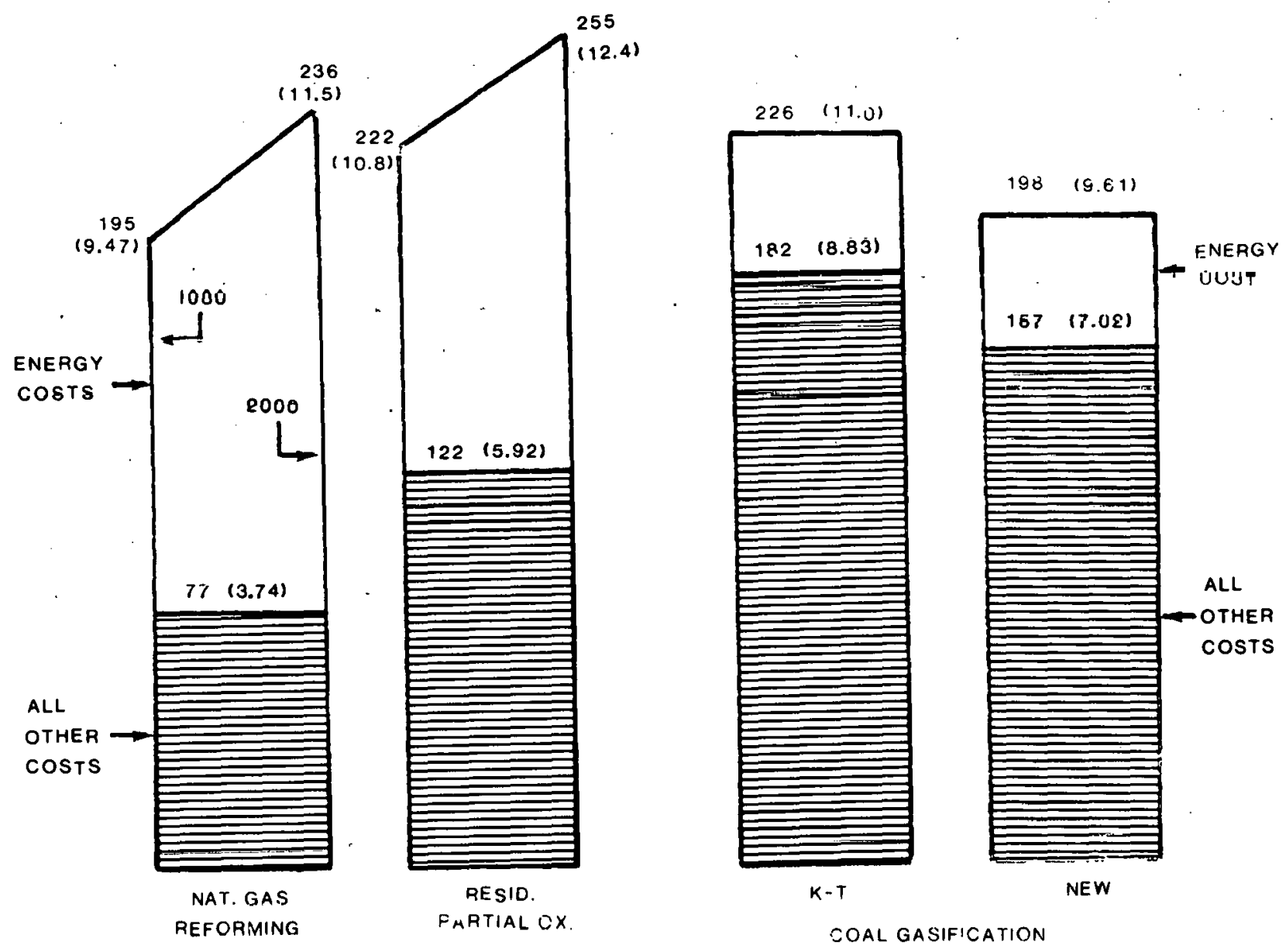

HIGHER HEATING VALUE BASIS: 10,259 BTU/LB.

A- 1978-12-056

Figure 4-5. METHANOL MANUFACTURING COSTS - MIDCONTINENT LOCATION 6 (\$/Short Ton, 2000 Tons/Day Plants, 1980 \$) (Note: Estimated $\$ 110^{6}$ Btu Costs are Fruvided Lu Purentheses ar $20.6 \times 10^{6} \mathrm{Btu} /$ short Ton (Higher Heating Valuel) 
Energy Corporation in June 1979. The assessment team was unable to acquire any documented results from this seminar in time to include in the current report. Based on several unofficial contacts, it is understood that hydrogen production costs of the order of $\$ 4 / \mathrm{million}$ Btu were projected by the participants. If so, this is a substantially lower estimate than those developed by Exxon Research and Engineering Co. (Figure 4-4) and by the Institute of Gas Technology. (See Bibliography Section 4 A.)

The comparison of coal conversion product costs with products produced via conventional means, however, may not be the deciding factor in selecting future hydrogen and methanol production facilities. Other factors such as reformer feedstock supply, recognition that coal conversion is a "next generation" production method, coupled with the need for operating experience and the potential to expand a facility to meet increased markets, may foster a switch to coal conversion plants somewhat before comparative product cost would otherwise dictate. In addition, Government support of initial projects can increase the attractiveness of earlier starts.

An example of this early switching to coal conversion is reflected in a current W.R. Grace Company project, which will provide a small coal gasification plant as part of an ammonia production facility. The coal conversion plant is currently in the preliminary design stage, supported by the DOE and is competing for continued DOE support with another coal conversion plant being designed for the production of industrial fuel gas. The latter project is being conducted by the Memphis Power and t.ight rompany -

Another example is a $10 \times 10^{6}$. SCF/day coal gasification plant being built to supply hydrogen in an ammonia plant at the Tennessee Valley Authority (TVA), National Fertilizer Development Center in Muscle Shoals, Alabama. This plant is expected to be operational by mid-1980. ${ }^{9}$ 
While it appears that coal conversion plants will be eventually built within the hydrogen and methanol industries, major activities are not anticipated until after $1990{ }^{10}$. However, once these plants are built, it is possible that some excess capacity (that which is planned to support near-term growth) will be available to support some transportation alternative fuel requirements. If this market then appears attractive to industry, the existing small plants could be enlarged and new plants constructed.

\section{Incentives and Special Supply Possibilities}

Another possible incentive for early application of coal fuels production facilities, and the subsequent potential of some portion of the installed capacity being available to support fuel cell/battery vehicles, is transportation use of gasoline-methanol blends. The advantage here is that methanol from domestic coal would displace expensive imported crude. However, certain components within present automotive fuel systems are not compatible with methanol. ${ }^{11}$ Examples of such incompatibilities include: common elastomeric seals and lines, certain plastic items, the tern-metal plating in fuel tanks, and possibly die-casting alloys used in fuel pump and carburetor components (long-term effects). Appropriate changes are indicated.

At least one other methanol-from-coal source warrants mention. In 1977, a study conducted for ERDA, Division of Transportation Energy Conservation, identified a potential methanol-from-coal source to support vehicle fleet tests. ${ }^{12}$ This source consisted of large coal gasification plants being planned in support of the natural gas industry. With the addition of a methanol synthesis unit, these plants would co-produce methanol and SNG. Driving this potential to produce methanol as a co-product is the requirement by several plants, those using the Rectisol tm gas. elean-up system, for methanol as a required clean-up system feed material. The study further 1dentified that a two unit, $250 \times 10^{6} \mathrm{Btu} / \mathrm{day}$ plant, planned by American Natural Gas and Peoples Gas Companies, would 
employ a methanol synthesis unit. Since this unit would be part of the first unit built and construction plans called for only one unit to be built initially, excess methanol production capacity would exist and could be used to support an alcohol fueled vehicle test fleet. This capacity however, would not be available upon completion of the second gasification unit. However, financing problems currently have all major U.S. SNG coal programs halted.

The Coal Supply Issue

There is little doubt that U.S. coal reserves are adequate to support the U.S. energy needs for many years. The Institute of Gas Technology recently estimated a coal-use life span of 104 years, based on a $4 \%$ coaluse growth rate and a recoverable reserve of $1036 \times 10^{9}$ tons. $^{13}$ with slower growth.rates, and/or more optimistic estimates of recoverable reserves, even longer coal based energy life times can be projected.

The concern in supplying the coal for projected new coal conversion plants is not the ultimate life span of the U.S. coal supply but the rate at which the coal industry can expand. As stated earlier, the industry has some unused capacity at the present time. ${ }^{14}$ In the next few years, this capacity will most likely be used up by both new and non-coal fired plants switching to coal. Once this capacity is in full use, the availability of coal for the synfuels industry, of which hydrogen and methanol may only be a minor part, and the electric power industry will depend on the attainable growth rate of the coal industry.

This growth rate; viewed realistically, is expected to be slow, probably about $2 \%$ per year, not the $7 \%$ which would be required to double coal production as called for in Project Independence. ${ }^{15}$

Figure 4-6 presents a graphical representation of the key factors and their interaction, which control the development of coal supply. 16 In this model, four delaying factors are indicated and these limit the 


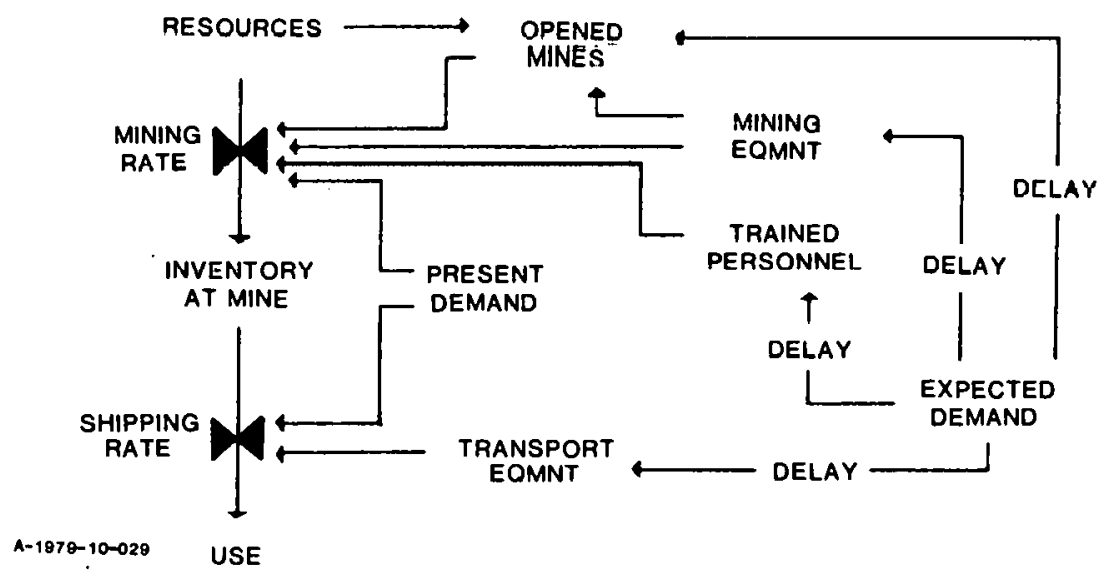

Figure 4-6. Coal Development System. 
coal industry growth once an expected demand occurs. Examples of these delay factors are:

- New Underground Mines: 7-10 years to reach full production ${ }^{14,15}$

- Mining Equipment:

- Surface: Drag lines take 5 years for delivery after date of purchase plus 6-18 months for on-site erection. 15

- Underground: About 1 year for delivery after date of purchase. ${ }^{15}$

- Coal Cleaning Plants: 3-3.5 years for construction. 15

- Labor: It takes 2-3 years to train underground miners plus there is real concern about the availability of potential miners to train and mining engineers.14,15

- Transportation:

- Rail: The rail industry will require major additions to their rolling stock. The current car building and locomotive industry is basically sized to meet replacement schedules. Thus, this industry must also expand.17

- Slurry Pipeline: Competes with rail in some cases, but requires railroad company rights-of-way approvals for implementation. It also requires large capital investment and water supplies, either being potentially limiting factors.

With the coal industry expected 'to grow at a slow but steady rate, the future availability of hydrogen and methanol from coal may well depend upon the strength of the market and the price which the hydrogen/ methanol industry can afford to pay for coal in the competitive market place.

Fuel Requirements of Fuel Cell/Battery Vehicles

First, it should be recognized that initial fleet demonstrations of fuel celi/battery automobiles, in analogy to the present electric vehicle situation, will have almost no effect on the hydrogen or methanol production industry. However, once the penetration reaches the $1 \%$ to $2 \%$ level (i.e., 1 to 2 million vehicles), the impact would be pronounced when measured in terms of the existing hydrogen and methanol market. But in terms of coal requirements, such a penetration would be very small compared with the current coal production level. Table 4-3 illustrates this point. 
Table 1-3. COMPARISON OF FUE- CELL/BATTERY FUEL REQUIREMENT RITE CURRENT U.S. METHANOL, HYDROGEN, AND COAL PRODUCTIJX

\begin{tabular}{|c|c|c|c|c|}
\hline $\begin{array}{ll}\text { Fuel Requirement } & \text { a } \\
\text { a } 2 \bar{z} \text { Penetration }\end{array}$ & $\begin{array}{l}1977 \text { Estimated Meth- } \\
\text { a.nol Demand }\end{array}$ & $\begin{array}{l}\text { Total } 1975 \mathrm{Hy}_{y-} \\
\text { drogen Demand b }\end{array}$ & $\begin{array}{l}\text { Soal Recuirəments }{ }^{\mathrm{c}} \\
\text { for } a \text { a } 2 \text { Peretration }\end{array}$ & $\begin{array}{c}1976 \text { U.S. Coal } \\
\text { Production }\end{array}$ \\
\hline & $-10^{12}$ Btu/year & & Hydrcger. Methanol & $-10^{6}$ ton $/ \mathrm{yr}$ \\
\hline
\end{tabular}

Assumed fuel effiziency $=3720$ Btu/mile. Average vehicle miles $=11,800$ miles/year $2 \%$ penetration $=2 \times 10^{6}$ vehicles. $1 \varepsilon$ 


\section{A Special Note: Methanol Vs. Fuel-Grade Methanol}

One issue bears special consideration regarding methanol from coal: its purity. As discussed by the Institute of Gas Technology, anticipated "fuel-grade methanol," which may be fully acceptable to combustion-based power systems vis-a-vis pure methanol (e.g., chemical or reagent grade), could pose problems in an onboard vehicle reformer type methanol fuel cell system: ${ }^{19}$

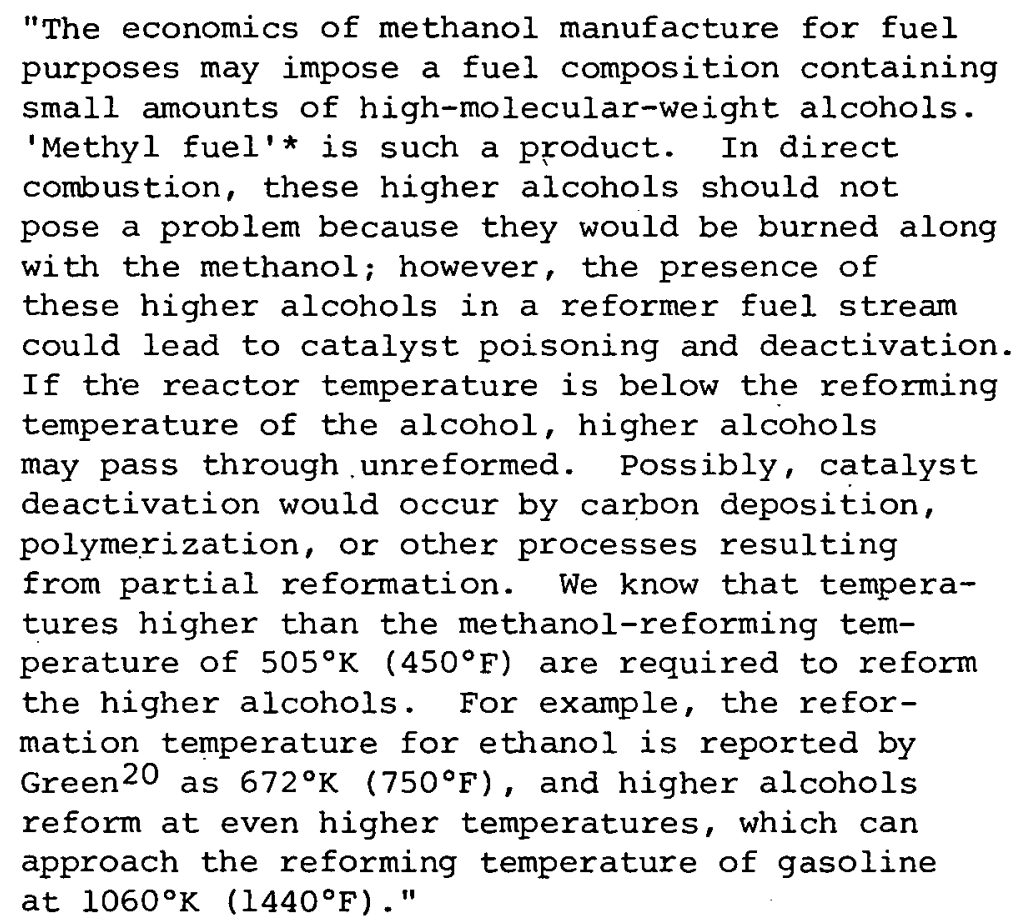

In its experimental evaluation of a representative methanol steam reforming catalyst unit, IGT indeed ran into difficulties with synthesized fuel-grade methanol after acheiving $98 \%$ conversion efficiency of laboratorygrade methanol over a 280-hour run. Their results and conclusions are stated below:

* Methyl fuel is a registered trademark of Vulcan-Cincinnati, Inc. It is a methanol-based fuel with controlled percentages of higher alcohols and essentially zero sulfur, nitrogen, and metals content. Other details are given in Reference 19. (IGT's Reference 19 is listed as Reference 20 in the present report.) 
"At the end of the laboratory-grade methanol run and after obtaining the space velocity and temperature effects data... we checked the condition of the catalyst by operating the reactor at the same conditions with a 1:1 molar laboratorygrade methanol-water mixture as fuel. Conversions of $98.4 \%$ of the methanol fed (for 30 hours) indicated that the catalyst was in good condition, so we changed the feed to fuel-grade methanol (98\% methanol, 1.7\% water, and $0.25 \%$ isobutanol, and $0.5 \%$ ethanol, by weight) and water ( $1: 1$ molar ratio). The conditions were the same as before, temperature ranging from $505^{\circ}$ to $510^{\circ} \mathrm{K}\left(450^{\circ}\right.$ to $460^{\circ} \mathrm{F}$ ) and a theoretical space velocity of $140 \mathrm{hr}^{-1}$. Immediately after the start of the run, we observed a drop in the amount of alcohol reformed, from the $98+8$ of the laturatory-gratle methanol run to 93\%. Furthermore, atter 40 hours of operation, we observed a substantial Arop in the amount of al,cohol reformed, frumi $93 \%$ after 40 hours to $70 \%$ at 140 hours. After 140 hours and to the end of the run at 530 hours, a certain stability was reached; the 'rate of deactivation' held to an average decreasing rate of $0.025 \%$ of methanol reformed per hour. The drop in $1 / 4$ reforming efficiency between 40 and 140 hours is attributed to carbon deposition* and deactivation, which might be the result of a loss of reaction sites and surface area. From 140 to 530 hours, the entire loss of reforming efriciency cuuld probably be attributed to catalyst deactivation.

"During thic run, chcelts on the eminusiliun uf the liquid collected showed traces of aldehydes, ethanol, and isobutanol. This indicates that dehydrogenation of alcohols occurred to a small extent and also that most of the higher alcohols were being reformed. Therefore, we concluded that the higher alcohols present in fuel-grade methanol resulted in a siynificant deactivation of activity over the 500-hour test run. We conclude that investigations are needed to clarify the mechanism of deactivation and to improve the catalyst's resistance to fuel-grade-methanol poisoning."

Figure 4-7 (Figure is from the IGT Reference 19) presents the data in a plot of percent methanol reacted vs. time. It shows both the lab-

\footnotetext{
* The catalyst at the end of the endurance test rontained 4.4\%
} carbon, by weight. 


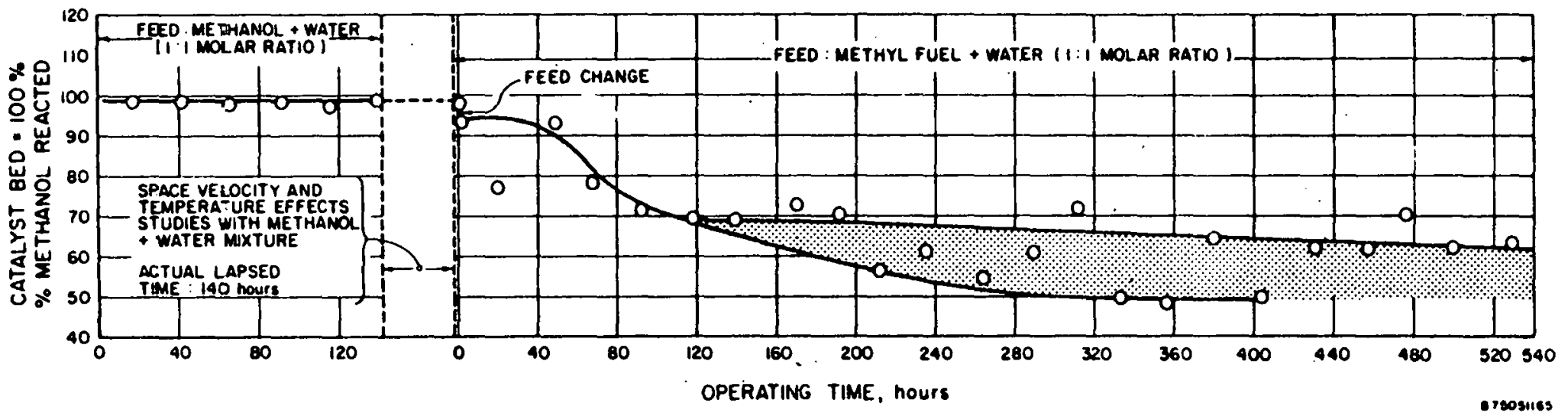

Figure 4-7. IGT Laboratory- and Fuel-Grade Methanol Steam Reforming Results 
oratory-grade methanol (left-hand portion of the plot) and the synthesized fuel-grade methanol (right-hand portion) performance.

Researchers at the Brookhaven National Laboratory have suggested two technical approaches for handling this potential problem with fuel-grade methanol. 21 The first is to avoid the problem by changing from the $1: 1$ molar ratio tested by IGT (see preceding quotation, $p .4-48$ ) to a $1: 1$ volume ratio. This has been shown experimentally to work well without producing catalysis deactivating carbon deposits.

The second approach BNL has suggested is applicable to catalyst bed reactivation, once such carbon deposits are formed. This can be done by simply heating the affected catalyst bed to the order of $600^{\circ} \mathrm{F}$. A third approach deals with the alcohol formulation itself and is described next.

The assessment team obtained expert opinion from a methanol-from-coal facility engineering firm regarding the technical and cost implications of specifying an upgraded (non-fuel) grade of methanol to avert this potential problem. A representative of Chem Systems, Inc., who contributed to the earlier BNL-supported study of methanol (and other chemicals) ${ }^{6}$ indicated the follgwing:

If initially designed for chemical-grade methanol, a coal-methanol plant would produce product at only slightly higher cost (i.e., 5\% to 10\%) than otherwise with fuel-grade product. ${ }^{22}$ Thus, it appears that the catalyst compatibility problem described in this special note can be obviated at little cost, provided effective planning is carried out regarding supply.

\section{References Cited in Section $4 \mathrm{E}$}

1. Cart, E.N., Jr., Carter, D.A., and Cunningham, A.R., "Alternate Energy Sources for Non-Highway Transportation," Appendixes for volume II-B, prepared for the U.S. vepartment of sinergy by the Exxon Research and Enqineerinq Company under Contract No. DE-ACO5-77CSO5438.

2. Cobb, C.B., "Energy and Hydrogen in the United States Refining Industry." Taper presented at the Workshop on Supply and Demand of Hydrogen as a Chemical Feedstock, University of Houston, Houston, Texas, December 12-14, 1977.

3. Alcohol Fuels Program Plan, March 1978, U.S. Department of Energy, DOE/US-0001/2. 
4. Corneil, H.G., "Production Economics for Hydrogen, Ammonia, and Methanol During the 1980-2000 Period." Paper presented at the Workshop on Supply and Demand of Hydrogen as a Chemical Feedstock University of Houston, Houston, Texas, December 12-14, 1977.

5. Cook, P.A.C., "Comments of Methanol." Paper presented at the Workshop on Supply and Demand of Hydrogen as a Chemical Feedstock, University of Houston, Houston, Texas, December 12-14, 1977.

6. Corneil, H.G., Heinzelmann, F.J., and Nicholson, E.W.S., "Production Economics for Hydrogen, Ammonia, and Methanol During the 1980-2000 Period," Final Report prepared for the Brookhaven National Laboratory by Exxon Research and Engineering Company, April 1977.

7. Gregory, D.P., and Tarman, P.B., "Hydrogen From Fossil Fuels," Paper presented at the International Symposium Hydrogen in Air Transportation, Stuttgart, Germany, September 11-14,1797.

8. Carrington, M., U.S. Department of Energy, personal communication of september 1979.

9. Lee, R.G., Tennessee Valley Authority, personal communication of September 1979.

10. Gregory, D.P., Institute of Gas Technology, personal communication of September 1979.

11. Anon., "The Report of the Alcohol Fuels Policy Review," U.S. Department of Energy, June 1979.

12. Barr, W.J., and Parker, F.A., "Sources of Alcohol Fuels for Vehicle Fleet Tests," Final Report for ERDA by America Energy Research Company, McLean, Virginia, August 1977.

13. Parent, J.D., "A Survey of United States and Total World Production, Proved Reserves, and Remaining Recoverable Resources of Fossil Fuels and Uranium," Institute of Gas Technology, Chicago, March 1979.

14. U.S. Department of Energy, Fossil Energy Division, personal communication of September 1979.

15. Anon., "Abundant Coal Feels Unready, Uncertain, Unloved," an Interview with Gerard C. Gambs, Vice President of Ford, Bacon and Davis, Energy 1 , No. 2, published by Business Communications Co., Inc., Winter 1976.

16. Decker, G.L., "U.S. Energy and Electricity Resources, Supply and Projections." Talk given at the Alternative Technologies of Electric Power Generation: Their Overali Fuel Cycles and Environmental Effects, University of California, Auqust 1977. 
17. Koper, J., Federal Railroad Administration, Office of Research and Development, personal communication of September 1979.

18. Shonka, D.B., Ed., "Transportation Energy Conservation Data Book," Edition 3 prepared for the U.S. Department of Energy by the Oak Ridge National Laboratory, ORNL-5493, February 1979.

19. Kester, F.L., Konopka, A.J., and Camara, E., "Automotive Storage of Hydrogen as a Mixture of Mtehanol and Water," Institute of Gas Technology report for ERDA, Report No. TEC-75/004, November 1975.

20. Garrett, D., and Wentworth,.T., "Methy1 Fuel - A Clean Source of Energy." Paper (No. 9) presented at the 166th National Meeting of the American Chemical Society, Chicago, August 26-31, 1973.

21. Private communication from J. McBreen via G. Strickland, Brookhaven National Laboratory, February 1980.

22. Private communication from J.F. Leonard, Chem Systcms, Inc., New York, New York, September 1979. 
F. PRELIMINARY COMPARATIVE VEHICLE SIMULATION FINDINGS AND

RELATED DISCUSSION

Background

As stated in Section 3, an additional unscheduled task was added to the assessment effort, based on the recognition of the isubstantial value of simulations of representative fuel cell/battery powered vehicle systems operating over several driving cycles.

This simulation work was carried out at LASL by Drs. B. McCormick and D. Lynn, and their contribution is acknowledged by the Assessment Team.

Objective of Task

It was desired to have documented representative, if preliminary, fuel cell/battery vehicle run data for both methanol- and hydrogen-fueled systems. Such parameters of interest as endurance and range, over several driving cycles, and ultimately some idea of fuel operating costs, were desired.

\section{Approach}

The IASL investigators utilized their existing computer program, which is capable of accepting real-hardware component characteristics operating over realistic operating ranges (not as lumped efficiencies) to simulate a fuel cell/battery power system. External factors such as aerodynamic drag, rolling friction, etc., are also realistically represented in the program:

Three driving cycles were operated within the limited investigation undertaken in support of the assessment:

1. Widc-open throttle-acceleration from standing start to a maximum sustained speed

2. SAE J227R Residential Cycle

3. SAE J227M Metropolitan Cycle.

Vehicle and Fuel systems simulated

The leading details of the vehicle simulation are presented in Appendix B. 
The vehicle was a version of the Volkswagen Rabbit passenger automobile converted to electric battery drive, and further to one of two fuel cell/battery power systems (employing conventional lead-acid batteries, viz., Sears Die Hardtm units).

- Methanol Fuel - using a phosphoric acid fuel cell and reformer - Hydrogen Fuel - using an alkaline fuel cell* fueled directly from the onboard hydrogen storage.

The methanol fuel cell system is essentially that described by Abens et al. and Onischak of Energy Research Corporation. 1 The fuel supply was an appropriate mixture of methanol and water. (Note: only the methanol per se is called out in the printouts provided.)

The hydrogen fuel cell system, as noted, was of the $\mathrm{KOH}$ alkaline electrolyte type specified only by a current-voltage characteristic curve (not provided here). 'l'he object1ve here was to capitalize un the availability of pure hydrogen fuel with the intrinsically higher efficiency alkaline cell (vis-à-vis the phosphoric acid cell, which operates optimally on hydrogen).

However, LASI investigators reported some. impedance mismatch problems when the alkaline cell was integrated into the existing vehicle power system. The hydrogen runs presented were somewhat compromised for this reason. Unfortunately, the resources available did not permit this problem to be resolved for the purpose of this repurl.

Since no specific hydrogen contaimment systems were detailed for this investigation, a simplified but technically valid approach was used in which three (3) hydrogen/total hydrogen containment system mass fractions were used as inputs: $0.01,0.05$, and 0.22 . 'These correspond

Characteristics of this fuel cell were provided to IASL by BNL. 
roughly to, respectively:

1. a state-of-the-art low-temperature metal hydride or highstrength pressurized gas storage container,

2. an advanced high-temperature metal hydride or a very sophisticated composite material pressure vessel, and

3. a demonstrated cryogenic liquid hydrogen vessel (viz., the MVE VLH-150 container ; see also Appendix D for current developments).

Two approaches were taken in making the runs: fixing maximum gross weight and fixing the stored energy amount.

The former tended to penalize the range and endurance of the 0.01 and, to a far lesser extent, the 0.05, mass-fraction hydrogen cases, although these had equivalent acceleration capabilities of the 0.22 hydrogen case and the methanol case.

The latter resulted in very high gross weights for the lower mass-fraction hydrogen cases. This resulted in low performance but yielded reasonable ranges. (However, the 0.01 hydrogen case was unable to follow the residential and metropolitan driving cycles.)

\section{Findings}

The results of the LASL driving cycle simulations are summarized in Table 4-4. Three hydrogen cases (equal stored energy/variable gross weight) and three methanol cases are included. A seventh gasoline case is included only for fuel operating cost comparison purposes. In this case, the gasoline costs are adjusted downward from the pump price to that equivalent to the hydrogen and methanol costs. (See explanatory notes.)

Also, it can be seen that the 0.010 hydrogen storage system case was unable to be operated on the residential and metropolitan driving cycles. This vehicle was simply too massive to provide the stipulated acceleration levels.

An. interesting finding is that the fuel operating costs ( $\xi / \mathrm{mile}$ ) for all cases are of the same general magnitude. 
Comparison of Simulations of various cases of $\mathrm{H}_{2}$ and Methanol fueled Fuel Cell/Battery Vehicle Systems in the Volkswagen "Rabbit" Vehicle Type. (Source: Dr. B. McCormick and Dr. D. Lynn, Los Alamos Scientific Laboratory, August 1979).

(Energy Storage Density of .220 is equivalent to present capability of Minnesota Valley Engineering Technology, .050 is equivalent to magnesium-titanium hydrides and best pressure cylinder technology, .010 is approximately equivalent to iron-titanium hydride storage technology.)

\begin{tabular}{|c|c|c|c|c|c|c|c|c|}
\hline & Run No. & 1 & 2 & 3 & 4 & 5 & 6 & 7 \\
\hline & Fue 1 & Hiyd. & Hyd. & Hyd. & Meth. & Meth. & Meth. & Gasoline \\
\hline & $\begin{array}{l}\text { Energy storage } \\
\text { Density, lb/lb } \\
\text { fueled tank wt. }\end{array}$ & $\begin{array}{c}.220 \\
\text { I1quid } \\
\end{array}$ & $\begin{array}{l}.050 \\
\text { Hyd } \\
\end{array}$ & $\begin{array}{l}.010 \\
\text { Hya } \\
\end{array}$ & .833 & .833 & .833 & $.82 n(e s t)$ \\
\hline & $\begin{array}{l}\text { Gross Vehıcie } \\
\text { Weight, lb }\end{array}$ & $34 \% 2$ & 3ysi & b3si & 3580 & 3580 & 3580 & 2900 (est) \\
\hline & $\begin{array}{l}\text { Fuel Cell } \\
\text { Type }\end{array}$ & Alk & Alk & Alk & Acid & Acid & Acid & - \\
\hline & No. of Cells (Fuel Cell) & 140 & 140 & 140 & 140 & 160 & 180 & - \\
\hline & 10s, mph & 29.9 & 27.4 & 20.2 & 30.0 & 33.0 & 34.9 & - \\
\hline & $30 \mathrm{~s}, \mathrm{mph}$ & 48.5 & 46.3 & 36.7 & 47.5 & 51.1 & 54.4 & - \\
\hline 10 & 100s, mph & 56.5 & 55.5 & 50.2 & 53.5 & 57.3 & 61.3 & - \\
\hline $\lim _{\in \rightarrow-1}$ & $\operatorname{Max} v_{1} \mathrm{mph}^{\mathrm{i}}$ & 56.7 & 55.9 & 51.6 & 53.6 & 57.3 & 61.6 & - \\
\hline 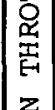 & $\begin{array}{l}\text { Fuel Consumption, } \\
\mathrm{mi} / \mathrm{lb}_{\mathrm{H} 2} \cdot \mathrm{mi} / \mathrm{gal} \\
\text { Meth }\end{array}$ & 23.9 & 22.7 & 17.8 & 21.6 & 21.4 & 18.7 & - \\
\hline 里 & Net Battery Charge & $\mathrm{D}$ & D & $\mathrm{D}$ & $\mathrm{D}$ & $\mathrm{D}$ & $\mathrm{C}$ & - \\
\hline 岁 & Fuel Cell Effic., avg.8 & 51.5 & 51.1 & 48.7 & 39.9 & 39.0 & 37.3 & - \\
\hline 3 & Vericle Range, ini & 717 & 681 & 534 & 648 & 842 & 581 & - \\
\hline & Cost per mile (Hi), $\quad$ c & 4.1 & 4.5 & 5.8 & 4.0 & 4.1 & 4.7 & $1.7^{2}-10.7$ \\
\hline & Cost por mile $(1,0)$, c & 3.6 & 2.2 & 2.8 & 2.2 & 2.2 & 2.5 & $1.7^{2} \mid \begin{array}{ll}3 & 0 \\
0 & 0\end{array}$ \\
\hline & $\begin{array}{l}\text { Fued Corisumption, } \\
\text { mi/lb } \mathrm{H}^{\prime} \text { "mi/gal Meth }\end{array}$ & 19.3 & 16.9 & $\star 3$ & 11.1 & 18.4 & 16.5 & - \\
\hline$\cong$ & Fuel Cell Effic., avg. 8 & 53.5 & 52.3 & $\star 3$ & 35.3 & 35.6 & 34.0 & - \\
\hline 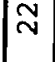 & Cost per mile (Hi), $i$ & 5.1 & 6.1 & $\star^{3}$ & 7.8 & 4.7 & 5.3 & $\left.5.2^{4}\right|_{\underline{0}} \underset{V_{1}}{+}=$ \\
\hline & Cost per mile (Lo), \& & 4.5 & 2.9 & $\star 3$ & 4.2 & 2.6 & 2.8 & 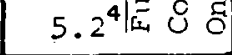 \\
\hline & $\begin{array}{l}\text { Fuel Consumption, } \\
\mathrm{mi} / 1 \mathrm{~b}_{\mathrm{H} 2} \mathrm{mi}^{\mathrm{gal}} \text { Meth }\end{array}$ & 14.9 & 12.2 & $\star 3$ & 9.3 & 15.9 & 14.9 & $\overline{-}$ \\
\hline$\Sigma$ & Fuel Cell Effic., avg. 8 & 51.1 & 50.2 & $\star^{3}$ & 36.4 & 35.5 & 33.4 & - \\
\hline$\approx$ & Cost per mile (Hi), $\zeta$ & 6.7 & 8.4 & $x^{3}$ & 9.3 & 5.5 & 5.9 & $5.2^{4}=118$ \\
\hline & Cost per mile (LO), \& & 5.8 & 4.0 & $\star^{3}$ & 5.1 & 3.0 & 3.2 & $5.2^{4}$ द C \\
\hline
\end{tabular}


Table 4-4, Cont. Constant Values and Notes

Constant Values:

Atmospheric Density $=0.0616 \mathrm{lb} / \mathrm{ft}^{3}$

Initial Battery Charge $=80 \%$

Power @. $6 \mathrm{~V}=20 \mathrm{Kw}$

Ampere Hours in Battery $=50$

Cells in Battery $=48$ (conventional lead-acid type)

Motors - 2 Baldors @ $10 \mathrm{HP}$ rating

Current Limit $=200$ amps

Transmission - EVAN @ 2800 rpm shift point

Rear End - 22 Diam at 4.148 final drive ratio

227 R - 227. Residential Driving Cycle

227 M - 227 Metropolitan Driving Cycle

For other details, see Appendix B

Notes:

1 - Maximum velocity is without field current reduction which can increase operating rpm to 3000-4000 a double power output. Vehicle could achieve speeds over 65 for limited time periods - equivalent to a "passing gear".

2 - Assumes 40 miles per gallon a $\$ 1.00$ per gallon - 4c(Fed. Tax) -10ф(State average Tax) - 15\& (Distribution and Station Operation costs) $=71 \%$ per gallon

3 - 0.01 energy storage density system, equivalent to Iron-Titanium Hydride, in Rabbit could not achieve required drive cycle velocity

4 - Assumes 30 miles per gallon, gas per 2 above.

Fuel Costs:

Source: Cant, E.N., et al, Alternate Energy Sources for Non-Highway Transportation, Exxon Laboratories, Final Report, Contract No. DE-ACO5-77CSO5438, for Ú.S. D.U.E., 1979

Methanol from Coal - $\$ 7.80$ to $\$ 14.40$ per $10^{6}$ Btu

Liquid Hydrogen from Coal - $\$ 16.70$ to $\$ 19.20$ per $10^{6}$ Btu

Gaseous Hydrogen from Electrolysis - $\$ 9.50$ to $\$ 19.50$ per $10^{6}$ Btu where the hydrogen is generated from utility electrical sources at high and low 1980 price estimates per kWhr.

A.1.1 prices are estimated for 1.980 
In performing the analyses presented in Table 4-4, the LASL investigators used a conservative approach in establishing their performance assumptions, e.g., available state-of-the-art component characteristics are assumed throughout. Further, the hydrogen-air fuel cell system does not represent an optimized configuration. For these reasons, the results shown are known to be conservative. 3

To illustrate this, the energy requirements for the various driving cycles are notably on the high side. 4 For example, the energy requirements for the 3937-pound vehicle (Table 4-4, column 2) on the J227R cycle are estimated as $502 \mathrm{Wh} /$ mile. Calculations for an all-battery vehicle on a similar cycle weighing 3909 poinds resulted in $275 \mathrm{Wh} / \mathrm{mile}{ }^{5}$

Optimized fuel cell/battery powered vehicles could complete these cycles with considerable less energy expenditures. This particular area of study, i.e., the optimization of fuel cell/battery vehicle systems deserves high priorities in further design analysis and simulation efforts. REFERENCES CITED IN SECTION 4F

1. McCormick, B., et al., Ed., "Froceedings of the Fuel Cell in Transportation Applications Workshop," held 15-17 August 1977, Los Alamos Scientific Laboratory Conference Proceedings, LA$7270-C$, July 1978 .

2. Escher, W.J.D., "Survey of Liquid Hydrogen Container Techniques for Highway Vehicle Fuel system Applications," DOE Report HCP/ M2752-01, November 1978.

3. Private communication with Dr. Byron McCormick, Los Alamos Scientific Laboratory, 26 December 1979.

4. Private communication with Dr. J. McBreen, Brookhaven National Laboratory, 6 November 1979.

5. Sheridan, D.L., Bush, J.J., and Kusiak, W.K., SAE Yaper No. $7601.19,1.976$. 


\section{APPENDICES}


THIS PAGE

\section{WAS INTENTIONALLY LEFT BLANK}




\section{APPENDIX A}

Excerpt from:

"Fuel Cells for Electric Vehicles," by Karl V. Kordesch, presented at the International Society of Electrochemistry, 28th Meeting, 18-23 September 1977

as reproduced in:

"Proceedings of the Fuel Cell in Transportation Applications Workshop," Los Alamos Scientific Laboratory Conference Proceedings, LA-7270-C, July 1978

\section{Comment:}

This paper excerpt provides a concise review of what has been accomplished with demonstration vehicle systems employing fuel cell and fuel cell/battery vehicles.

Not mentioned, however, is the MERADCOM fork lift truck and the more recent LASL golf cart test unit discussed in the text.

Figures and references presented are excerpted and included here. 
THIS PAGE

\section{WAS INTENTIONALLY LEFT BLANK}




\section{A. With Hydrogen Fuel Cells}

In spite of the experimental nature of many fuel cell batteries, demonstration vehicles powered by them have provided much experience for future developments. One of the first vehicles was a tractor built by Allis-Chalmers Mfg. Co. in 1959. It was powered by a $15-\mathrm{kW} \quad \mathrm{H}_{2}-\mathrm{O}_{2}$ battery using asbestos separators to immobilize the. $\mathrm{KOH}$ electrolyte. The current density was only $20 \mathrm{~mA} / \mathrm{cm}^{2}$, therefore the battery weight was $917 \mathrm{~kg}(19)$. The same company demonstrated operation of a golf cart and a lift truck, powered by a 3-kW hydrazine-oxygen fuel cell battery, in 1963 (20). In 1965 Shell Research Labs. in Thornton, England, operated a 5-kW $\mathrm{H}_{2}$-air fuel cell a attery-powered small truck. Hydrogen was obtained by steain reforming of methanol (19).

Probably the most extensive study of a fuel cell-powern, venicle was done by Genera? Motors (1965-66). A six-passenger van was selected for this project because it allowed room for instrumented experimentation. The motor was a 125-hp $(13,700$ rpm) three-phase, electronically controlled induction motor. The fuel cell battery (built by Union Carbide Corp.) consisted of a 32-module $\mathrm{H}_{2}-\mathrm{O}_{2}$ battery with a nominal output of $32 \mathrm{~kW}$ and a peak power of $160 \mathrm{~kW}$. Figure 6 shows a sketch of the "Electrovan" (21). The program demonstrated that fuel cell technology had reached a point (in 1965) where high output for vehicles was attainable. The total fuel cell power. plant weight was $1500 \mathrm{~kg}$ (energy density: $10 \mathrm{~kg} / \mathrm{k} / \mathrm{W})$ and the performance concerning speed $(115 \mathrm{~km} / \mathrm{h} \max )$ and acceleration $(0-100$ $\mathrm{km} / \mathrm{h}$ in $30 \mathrm{sec}$ ) was satisfactory. Driving ranqe of the vehicle was cryogenic hydrogen and oxygen was $250 \mathrm{~km}$. However, evalilation tests also defined many points that were unsatisfactory: (1) heavy weight (100\% overweight); (2) complicated start up and shutdown procedures; (3) use of cryogenic liquids (especially oxygen), and (4) short life of batteries, even when not used. It was considered necessary to operate with oxygen rather than dir to obtain the top speed and the desired acceleration behavior.

A hybrid system consisting of a fuel cell battery in parallel with a lead-acid battery reduces weight, removes starting delays. allows the use of air, and provides the possibility for intermittent operation of the fuel cell system, by keeping it deactivated when the vehicle is not in use. The accumulative operating life of the fuel cell (e.g., 5000 hours) is then the same as that of a combustion engine. The author built such a test vehicle (22) which proved all these points during urban driving over a period of four years (1971-75) for a total of $21,000 \mathrm{~km}$. The same hydrogen-air battery would have lasted only 5000 hours $(=1 / 2$ year $)$ if kept continuously active. Figure 7 shows the principal circuit diagram of the hybrid power plant. The lead-acid battery in the front of the car consisted of seven 12-volt batteries ( $84 \mathrm{~V}, 90 \mathrm{Ah})$; weight: $150 \mathrm{~kg}$; maximum power output: $20-30 \mathrm{~kW}(200 \mathrm{~W} / \mathrm{kg})$. Figure 8 shows the diagram of the 90-V hydrogen-air fuel cell battery capable of $6-\mathrm{kW}$ continuous output. The vehicle was a four-passenger compact car (converted Aust in A-40) with a curb weight of $1000 \mathrm{~kg}$, complete with six steel cylinders (weight: $80 \mathrm{~kg}$ ) and containing $25 \mathrm{~m}^{3}$ of hydrogen at $130 \mathrm{~atm}$ (equivalent to $45 \mathrm{kWh}$ ), thus assuring a driving range of $300 \mathrm{kln}$. The energy density of the fuel cell system (total weight: $250 \mathrm{~kg}$, including tanks) was 140 Wh/kg. During operation of the hybrid system there is fully automatic load sharing between the batteries. This load sharing can be described in a power or energy profile $(6)$, which more than satisfies the demands for the commuter car listed in Table 1 and pictured in Fig. 3.

The improvement of the air electrode power output by a factor of two (from 100 to $200 \mathrm{~mA} / \mathrm{cm}^{2}$ ) achieved within the past five years brings the fuel cell output to a level of 10 to $15 \mathrm{~kW}$. This means saving $50 \%$ of the lead battery weight, perhaps indicating that a nickel oxide-hydrogen battery (23) would be a far better (lighter) choice than the lead battery, and would provide even higher peak currents putting less importance on energy density. This would also open up the field for exploring "internal hybrid" fuel cells ( $\mathrm{MeOx}, \mathrm{C}, \mathrm{air} / \mathrm{KOH} / \mathrm{H}_{2}$ ) to allow even more weight and volume savings.

*Table 1 and Fig. 3 are not presented in this abridged version. 
The advantages of a fuel cell-hybrid battery vehicle using compressed $\mathrm{O}_{2}$ was extensively studied (8). The unavailability of a low cost, high power electrode at that time (1974) was probably the reason for choosing $0_{2}$. Systems using hydrogen (as compressed gases) can be considerabiy improved if recent work on reversible sturage of hydrogen in special alloys proceeds successfully (24). The use of liquid ammonia as a hydrogen source in combination with a catalytic decomposition unit also seems to be very practical (25).

\section{B. With Liquid-Fuel Fuel cells}

With the exception of the previously mentioned vehicles $(19,20)$ which employed methanol (converted) and hydrazine cells only, all others used hybrid systems. In 1966, the author built a motorcycle system consisting of a 16-V, 800-W Union Carbide hydrazine-air battery and a powerful (2.5-kW) nickel-cadmium battery. The motorbike was able to cruise at $40 \mathrm{~km} / \mathrm{h}$ and had a range of over $200 \mathrm{~km}$ on 4 liters of hydrazine monohydrate (2). In 1968, the US Army in cooperation with Monsanto Research Corp. developed a 28- $V, 20-k W$ hydrazine-air battery for a 3/4-ton M-37 Army truck. A lead-acid battery was used to provide instant maneuverability (2). In operation, the specific power density was $100 \mathrm{~W} / \mathrm{kg}$. The practical energy density of the fuel $\left(\mathrm{N}_{2} \mathrm{H}_{4}\right.$ $\mathrm{H}_{2} \mathrm{O}$ ) was assumed to be $1 \mathrm{~kW} / \mathrm{kg}$ for purposes of calculating the vehicie's range.

She 11 Research, Ltd. (England) developed hydrazine-dir batteries since 1967 and achieved power densities of $150 \mathrm{~W} / \mathrm{kg}$. A passenger car (a converted DAF-44) with a weight of $1380 \mathrm{~kg}$ was powered by a hydrazine-lead hybrid system (26). The schematic diagram of this system is pictured in Fig. 9. The load sharing of the fuel cell and lead battery can be derived from Fig. 10. The car's performance in city traffic was similar to the gasoline version.

\section{References}

2. Batteries, Vol. 2, Lead Acid Batteries and Electric Vehicles, K. V. Kordesch (ed), Chap. 2, The Electric Automobile, by K. V. Kordesch, Marcel Dekker, New York, 1977.

6. K. V. Kordesch, Performance of Lead Batteries in a Generator Hyorid Vehicle, 28th Meeting of ISE, Varna, Bulgaria (1977).

8. A. Michel and W. Frie, Paper No. 7452, Third International clectric Vehicle Symposium, Washington, 0.C. 1974.

19. K. R. Williams, 2nu Interil. Püwer Sources Symp., Orighton, 1968; also Advances in Chemistry Series 90, p. 366, Amer. Chem. Soc., 1969.

20. R. Jasinski and T. G. Kirkland, Research Div. of Allis Chalmers Mfg. Co., Mtlwaukee, Sept. and Dec. 1963.

21. C. Marks, E. A. Rishavy and F. A. Wyczalek, SAE Paper 670176, Automotive Engineering Congress, Detroit, Mich., Jan. 9-13, 1967.

22. K. V. Kordesch, J. Electrochem. Soc., 118, 815 (1971).

23. K. V. Kordesch and S. J. Cieszewski, Paper No. 17 , ioth Intern. Power Source Conf., Brighton, 1976 .

24. C. E. Lund in and F. E. Lynch, Paper Nos. 759201 and 759202, 10th IECEC Proceedings, Newark, Del., Auy. 1975 .

25. 0. J. Adlhardt, Paper No. 729163, 7th IECEC Meet ing, Amer. Chem. SoC., Washington, D.C., 1972 .

26. M. R. Andrew, W. J. Gressler, J. K. Johnson, $R$, T, Short, and $K, \quad R$, Williams, Paper No: 720181 , Automotive Engineering Congress, Soc. of Automotive Engineers. New York, 1972. 


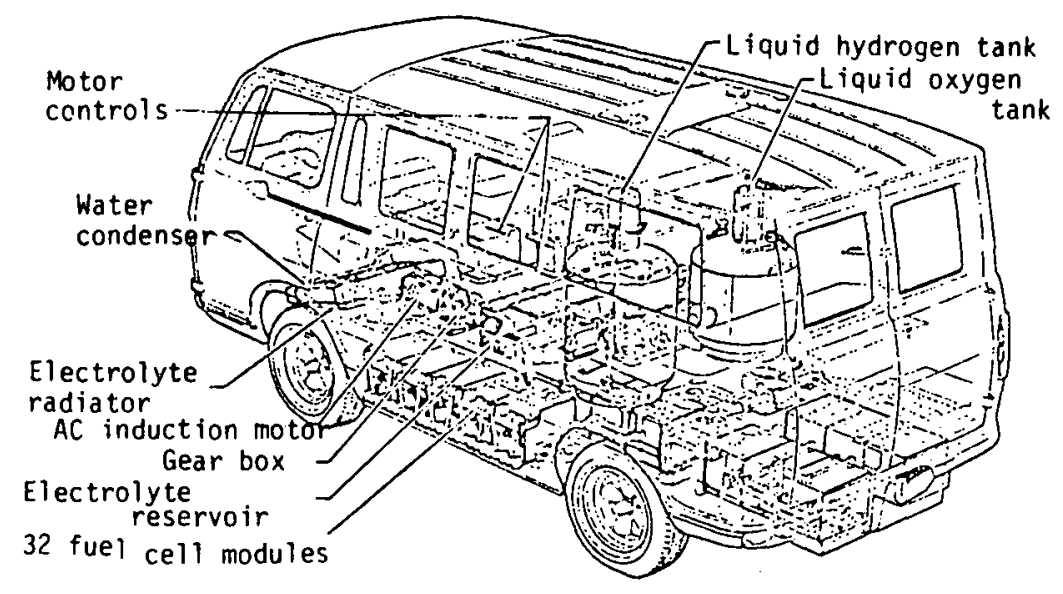

Figure 6. General Motors Electrovan.

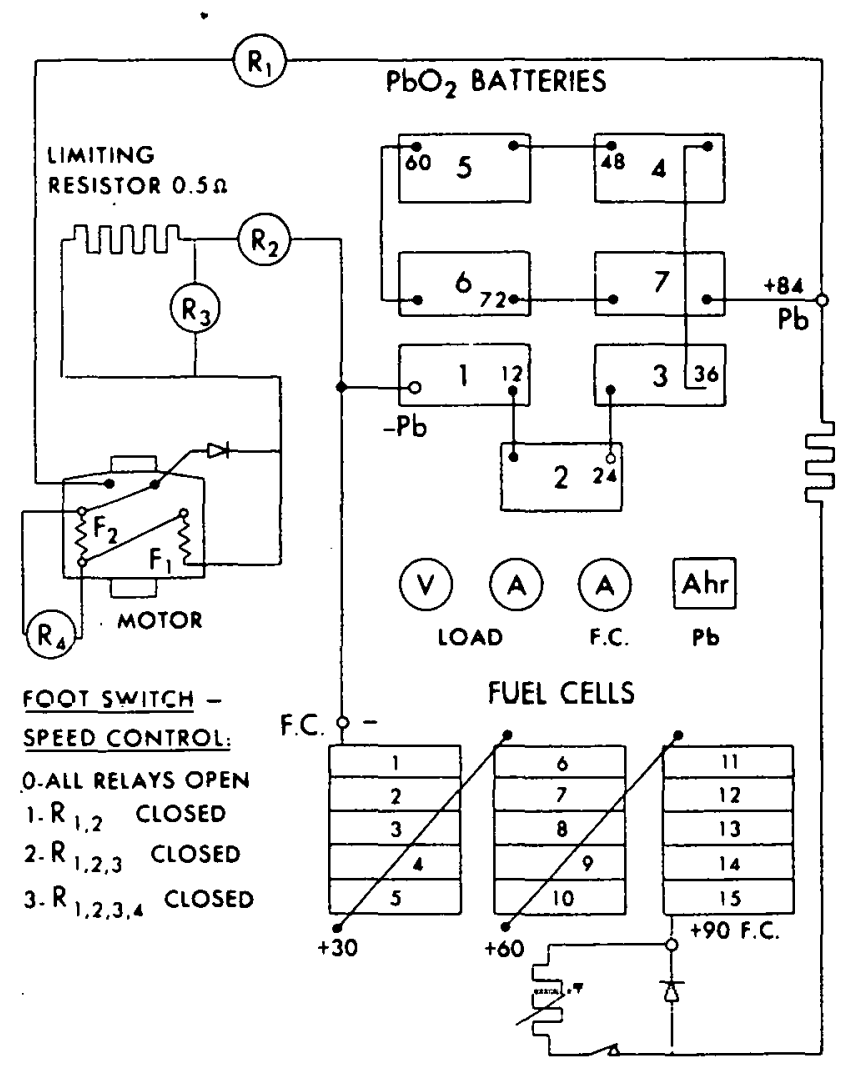

Figure 7. Principle Circuit of the Hybrid Powerplant of the Electric Car Built by the Author in 1970 . 


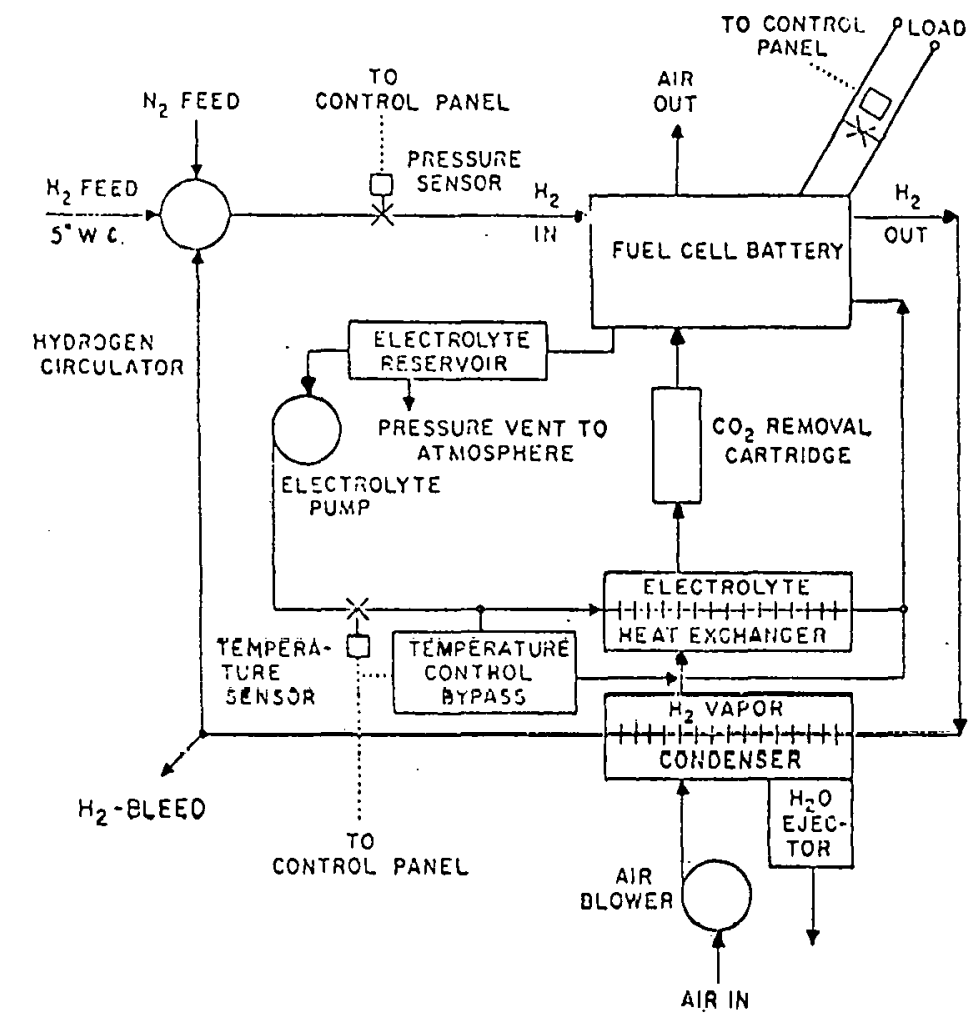

Figure 8. Diagram of a Hydrogen-Air Fuel Cell System Built by Union Carbide Corp. (1970).

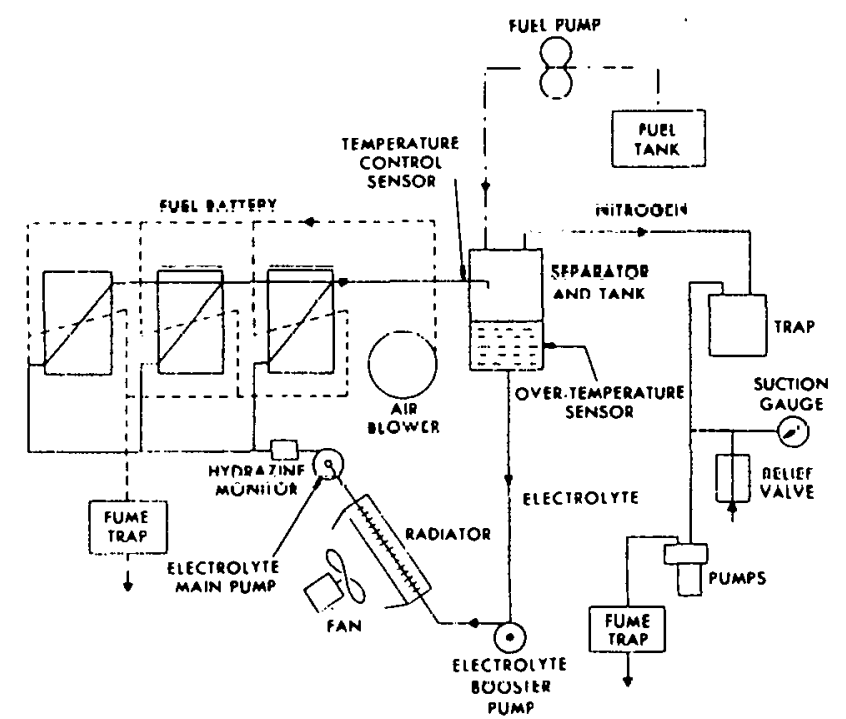

Figure 9. Hydrazine-Air Powerplant of the Shell-DAF 44 Electric Automobile (1972).

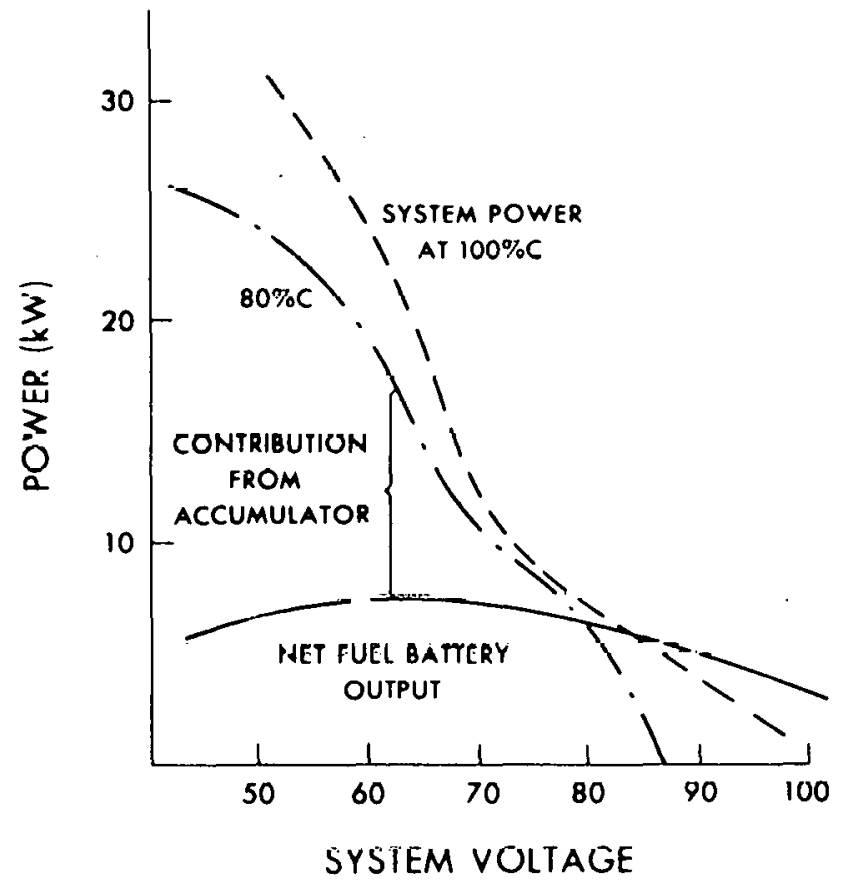

Figure 10. Load Sharing Diagram of the DAF 44 "Hybrid Car. 


\section{APPENDIX B}

B-I Methanol Example Run

B-II Liquid Hydrogen Example Run

Source: LASL, August-September 1979

Dr. Byron McCormick

Dr. David Lynn 
APPENDIX B-I

METHANOL RABBIT VEHICLE SIMULATION RUN 
METHANOL

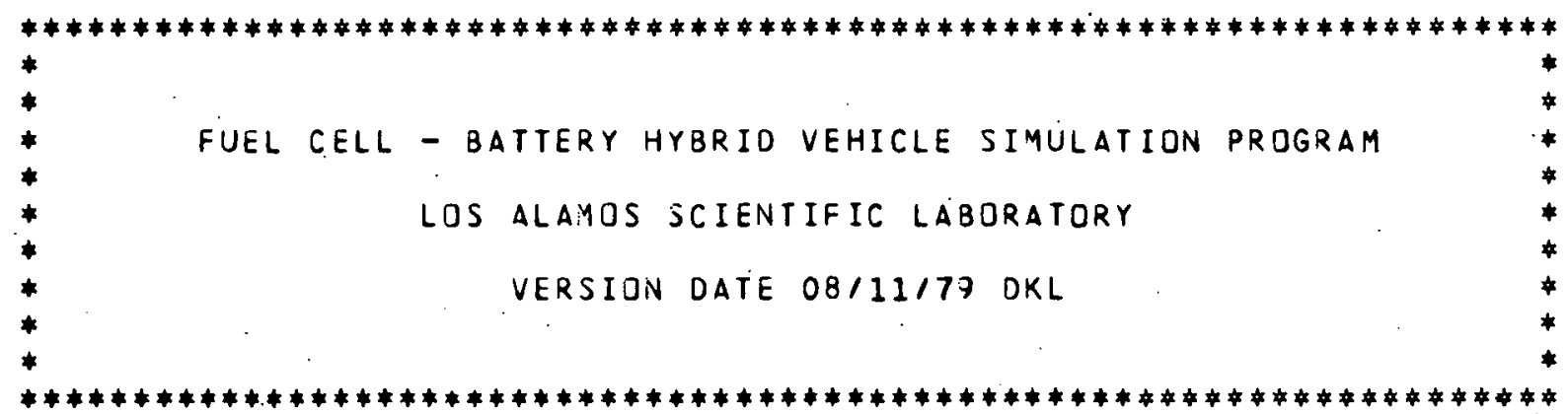

ACID FUEL CELL/BATTERY ELECTRIC RABBIT

FILE NAME: RABBT?

BATTERY: 48 CELLL, 50AH, 4. OKWH (20HR), 55LB/KWH

FUEL CELL: 160 CELLS, $1.39 \mathrm{FT} * 2,34 \mathrm{LB} / \mathrm{K} N$

$P=160 * .6 * 150 * 1.39=20 \mathrm{KW}$

REMOVED UPPER CURRENT LIMITS ON FUEL CELL AND BATTERY

THE LOWER FC AND BTTRY CURRENT LIMITS ARE I = O, I = -BAH

BATTERY $V$ IS A STRAIGHT LINE FRDM I = O TO I = 5*BAH

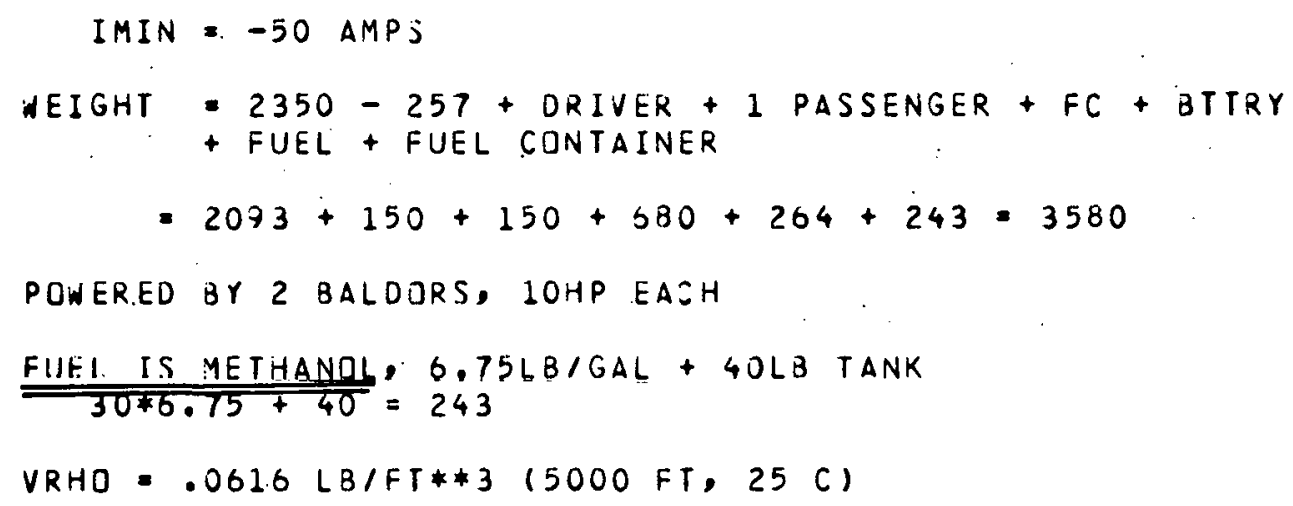

Re: Vehicle weight Breakdown

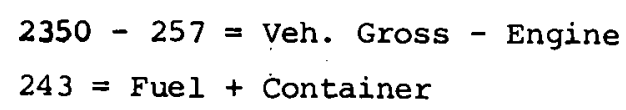




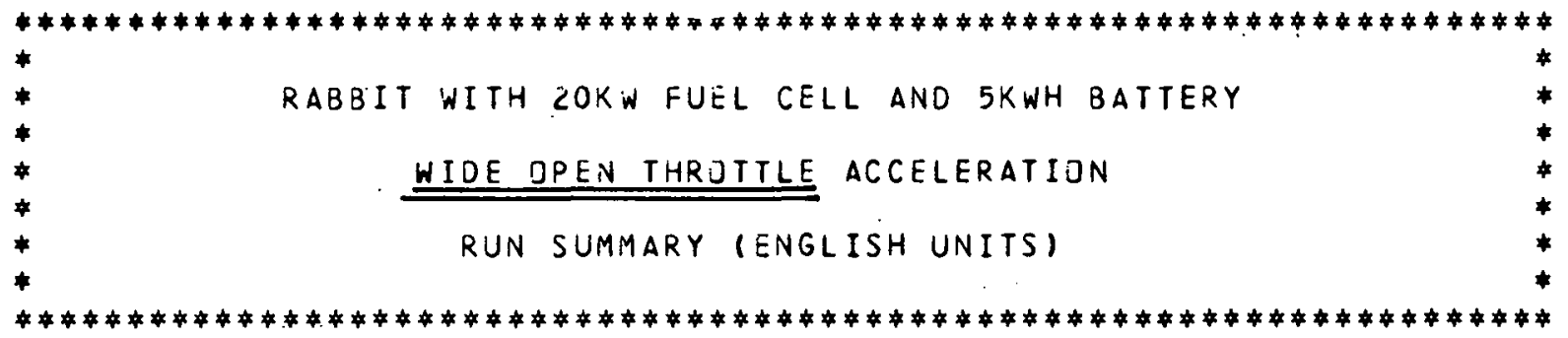

\begin{tabular}{|c|c|c|c|}
\hline $\begin{array}{l}\text { TIME (SEC) } \\
\text { AVLRACE SPCCD (MPH) } \\
\text { AVE MUIUK KPM }\end{array}$ & $\begin{array}{l}.00 \\
.11 \\
.48\end{array}$ & $\begin{array}{l}\text { DISTANCE (MILES) } \\
\text { FINAL SPEEU } \\
\text { AVERAGE THROTTLE }\end{array}$ & $\begin{array}{l}79.32 \\
37.20 \\
.9999\end{array}$ \\
\hline $\begin{array}{l}\text { INITIAL BATTTERY CHARGE } \\
\text { MIN BATTERY CHARGE }\end{array}$ & $\begin{array}{l}.3000 \\
.6386\end{array}$ & $\begin{array}{l}\text { FINAL BATTERYY. CHAR,GE } \\
\text { AT TIME }\end{array}$ & 3000.00 \\
\hline $\begin{array}{l}\text { TOTAL METHANOL (GAL) } \\
\text { FUEL FOR RECHARGE }\end{array}$ & $\begin{array}{r}3.71 \\
. .12\end{array}$ & $\begin{array}{l}\text { AVE MILEAGE (MPG) } \\
\text { RECHARGE TIME (SEC) }\end{array}$ & $\begin{array}{r}21 \cdot 36 \\
1752 \cdot 23\end{array}$ \\
\hline
\end{tabular}

FUEL CELL

BATTERY (DIS)

BATTERY (CHG)

SOURCE

CONTROLLEK

MOTOR

DRIVE TRAIN

SOURCE TO WHEEL EFF

VELOCITY

MUTOR POWER

FUEL CELL CURRENT

BATTERY DISCHARGE CURRENT

BATTERY CHAROE CURRENT

SOURCE CURRENT

MOTOR RPM

$\begin{array}{crc}\text { AVERASE } & \text { AVERAGE } & \text { AVERAGE } \\ \text { PONER OUT } & \text { CURRENT } & \text { EFFICIENCY } \\ (\text { HP) } & & \\ 25.59 & 197.21 & .3900 \\ .58 & 4.48 & \\ .00 & .00 & \end{array}$

26.17

25.07

21.11

18.35

201.69

201.74

.9530

.8420

.8935

.7207
TIME

170.00

11.00

11.00

.10

0.00

.10

170.00 
METHANOL

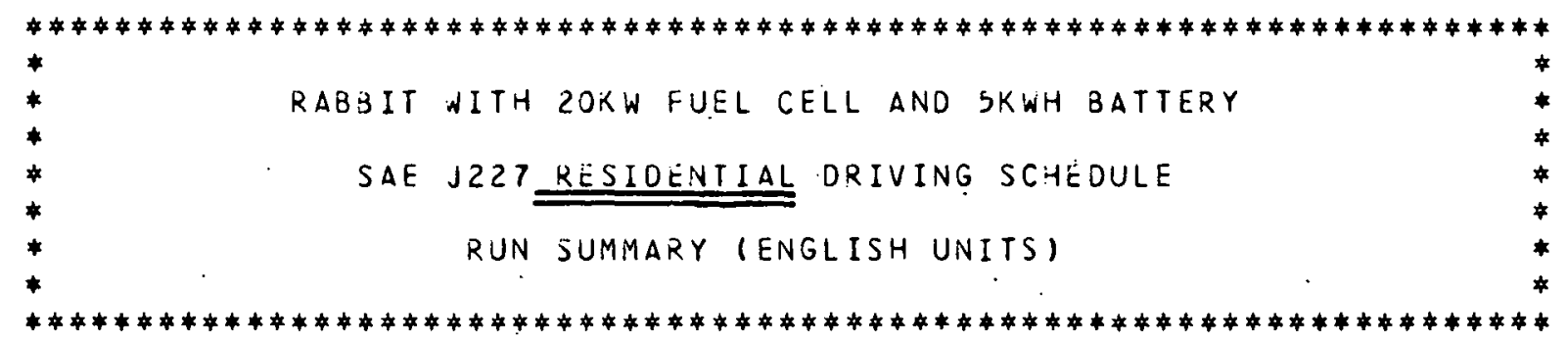

$\begin{array}{lcll}\text { TIME (SEC) } & 300.00 & \text { DISTANCE (MILES) } & 1.75 \\ \text { AVERAGE SPEED (MPH) } & 21.02 & \text { FINAL SPEED } & 0.00 \\ \text { AVE MDTOR RPM } & 1628.17 & \text { AVERAGE THROTTLE } & .3516 \\ \text { INITIAL BATTERY CHARGE } & .8000 & \text { FINAL BATTERY CHARGE } & .7964 \\ \text { MIN BATTERY CHARGE } & .7933 & \text { AT TIME } & 237.50 \\ & & & \\ \text { TOTAL METHANDL (GAL) } & .10 & \text { AVE MILEAGE (MPG) } & 18.44 \\ \text { FUEL FOR RECHARGE } & .01 & \text { RECHARGE TIME (SEC) } & 175.07\end{array}$

FUEL CELL

3ATTERY (DIS)

BATTERY (CHG)

SOUREE

CONTROLLER

MOTOR

DRIVE TRAIN

SOURCE TO WHEEL EFF

VELOCITY

MOTOR POWER

FUEL CELL CURRENT

BATTERY DISCHARGE CURRENT

BATTERY CHARGE CURRENT

SOURCE CURRENT

MOTOR RPM

$\begin{array}{ccc}\text { AVERAGE } & \text { AVERAGE } & \text { AVERAGE } \\ \text { POWER OUT } & \text { CURRENT } & \text { EFFICIENCY } \\ \text { (HP) } & & \\ 9.27 & 69.63 & .3560 \\ 2.15 & 15.17 & \\ 1.46 & 9.31 & \\ 8.48 & 75.54 & \\ 8.04 & & \\ 6.59 & 114.50 & .9484 \\ 5.95 & & .8194 \\ & & .9027 \\ & & .7015\end{array}$

T IME

237.50

20.77 .

170.53

20.16

199.00

20.16

182.11

COMPLETED 2 DRIVE CYCLES. 
METHANOL

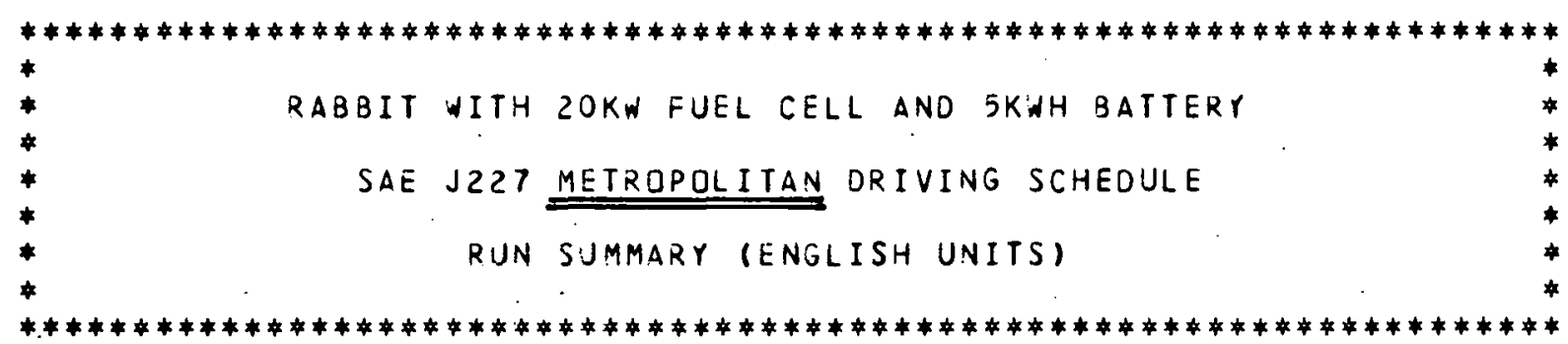

$\begin{array}{lcll}\text { TIME (SEC) } & 300.00 & \text { DISTANCE (MILES) } & 2.09 \\ \text { AVERAGE SPEED (MPH) } & 25.05 & \text { FINAL SPEED } & 0.00 \\ \text { AVE MOTOR RPM } & 1849.23 & \text { AVERAGE THROTTLE } & .3970 \\ & & & \\ \text { INITIAL BATTERY CHARGE } & .8000 & \text { FINAL RATTERY CHARGE } & .7755 \\ \text { MIN BATTERY CHARGE } & .7730 & \text { AT IIME } & 250.00 \\ \text { TOTAL METHANOL (GAL) } & .13 & \text { AVE MILEAGE (MPG) } & 15.93 \\ \text { FUEL FOR RECHARGE } & .02 & \text { RECHARGE TIME (SEC) } & 343.81\end{array}$

FUEL CELL

BATTERY (OIS)

BATTERY (CHG)

SQURGE

CONTROLLER

MOTOR

DRIVE TRAIN

SOURCE TO WHEEL EFF

VELOCITY

MOTOR POWER

FUEL CELL CURRENT

RATTERY DISGHAPGE GURRENT

BATTERY CHARGE CURRENT

SUUREE CURRENT

MOTOR RPM

$\begin{array}{ccc}\text { AVERAGE } & \text { AVERAGE } & \text { AVERAGE } \\ \text { POWER OUT } & \text { CURRENT } & \text { EFFICIENCY }\end{array}$

( $H P$ )

12.13

1.88

2.89

93.93
14.44
9.27

$12 \cdot 0.8$

11.31

9.17

8.39

79.10
129.12

.9363

.8110

.9144

.6944
TIME

100.00

81.62

170.53

20.16

271.00

20.16

100.00

COMPLETEO 2 DRIVE CYCLES 
APPENDIX B-II

LIQUID HYDROGEN RABBIT VEHICLE SIMULATION RUN

$-93-$ 


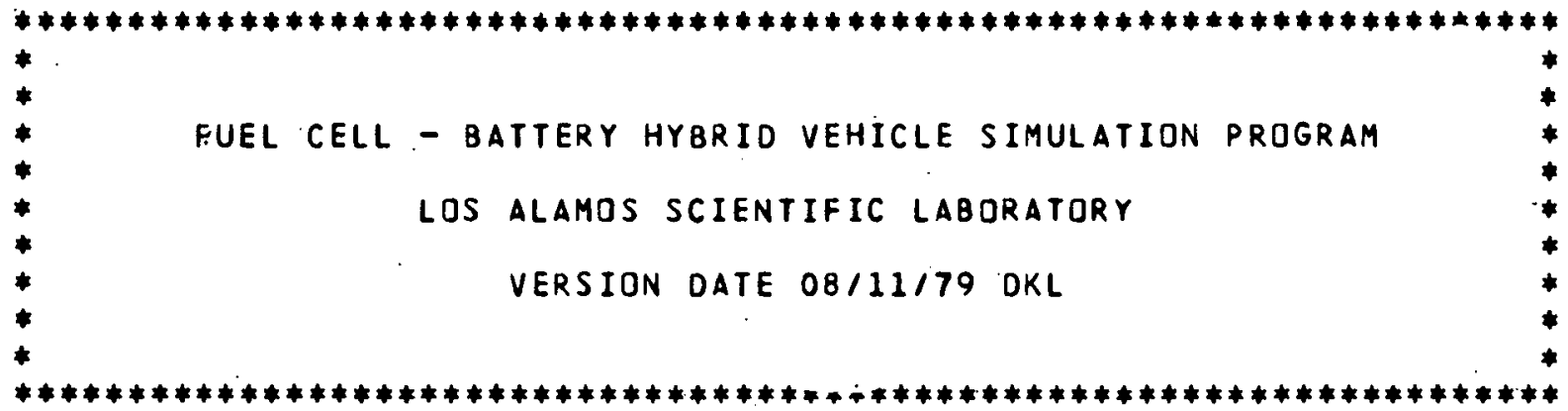

ALKALINE FUEL CELL/BATTERY ELECIRIC RABBIT

-FILE NAME: RABBT2

BATTERY: 48 CELLS, 50AH, 4.8KWH (20HR), 55LB/KWH

FUEL CELL: 140 CELLS, 1.47 FT*2, 34LB/KW

$P .140 * .605 * 161 * 1.47=20 \mathrm{KW}$

REMOVED UPPER CURRENT LIMITS ON FUEL CELL AND BATTERY

THE LOWER FC AND BTTRY CURRENT LIMITS ARE I : O. I = -BAH

BATTERY $V$ IS A STRAIGHT'LINE.FROM I = 0 TOI I = 5*BAH

IMIN $=-50$ AMPS

WEIGHT - $2350-257$ + DRIVER + 1 PASSENGER + FC + BTTRY

+ FUEL + FUEL CONTAINER

$=2093+150+150+680+264+135 \cdot 3472$

POWERED BY 2 BALDORS, IOHP EACH

FUEL IS LIQUID HYOROGEN, FUEL + CONTAINER WEIGHS 4.5LBSILB OF.H2

VRHO .0616 LB/FT*3(5000 FT. 25 C)

Re: Vehicle Weight Breakdown

$2350-257=$ Veh. Gross - Engine

Hydrogen Weight $=30$ pounds 


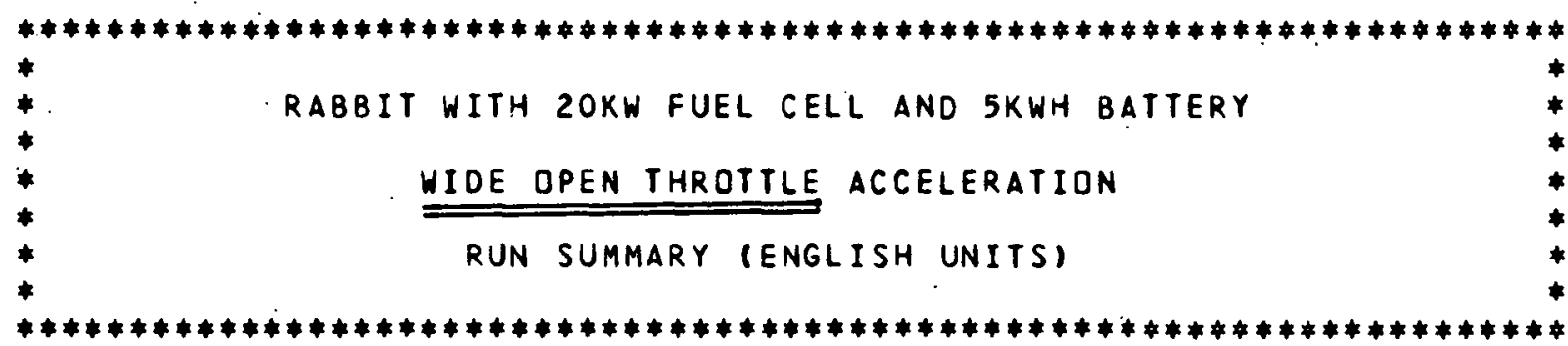

$\begin{array}{lcllr}\text { TIME (SEC) } & 5000.00 & \text { OISTANCE (MILES) } & \mathbf{7 7 . 7 0} \\ \text { AVERAGE SPEED (MPH) } & 55.95 & \text { FINAL SPEED } & 55.76 \\ \text { AVE MOTOR RPM } & 3548.02 & \text { AVERAGE THROTTLE } & .9999 \\ \text { INITIAL BATTERY CHARGE } & .8000 & \text { FINAL BATTERY CHARGE } & .3581 \\ \text { MIN BATTERY CHARGE } & .3581 & \text { AT TIME } & 5000.00 \\ & & & \\ \text { TOTAL FUEL USED (LB) } & 3.26 & \text { AVE CONS (MIILB) } & 23.85 \\ \text { FUEL FOR RECHARGE } & . .26 & \text { RECHARGE TIME (SEC) } & 3399.77\end{array}$

FUEL CELL

BATTERY (DIS)

BATTERY (CHG)

SDURCE

CONTROLLER

MOTOR

DRIVE TRAIN

SOURCE TO WHEEL EFF

$\begin{array}{crc}\text { AVERAGE } & \text { AVERAGE } & \text { AVERAGE } \\ \text { POWER OUT } & \text { CURRENT } & \text { EFFICIENCY } \\ \text { (HP) } & & \\ 23.43 & 185.65 & .5153 \\ 1.30 & 10.37 & \\ .00 & .00 & \end{array}$

24.73

23.69

19.96

17.80

196.02

196.03

.9581

.8427

.8917

.7199
VELOCITY

MOTOR POWER

FUEL CELL CURRENT

BATTERY DISCHARGE CURRENT

BATTERY CHARGE CURRENT

SOURCE CURRENT

MOTOR RPM

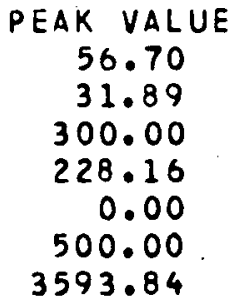

TIME

195.00

2.63

1.00

.10

0.00

.10

195.00 


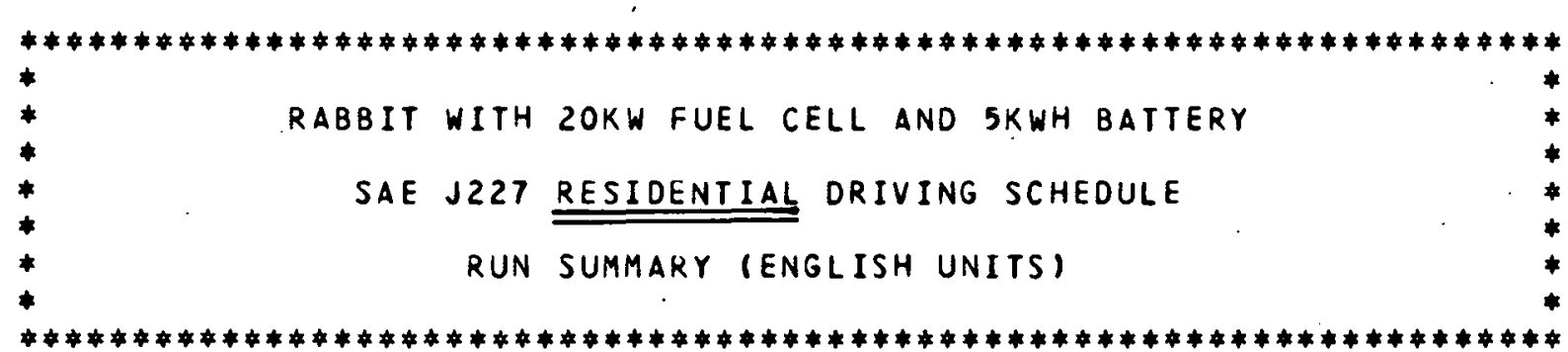

$\begin{array}{lcll}\text { TIME (SEC) } & 300.00 & \text { DISTANCE (MILES) } & 1.75 \\ \text { AVERAGE SPEED (MPH) } & 21.02 & \text { TINAL SPEED } & 0.00 \\ \text { AVE MOTOR RPM } & 1620.34 & \text { AVERAGE THRUTILE } & .3479 \\ \text { INITIAL RATTFRY CHARTE } & .4000 & \text { FINAL BATTERY CHARGE } & .7730 \\ \text { MIN BATTERY CHARGE } & .7683 & \text { AT TIME } & 237.50 \\ \text { TOTAL FUEL USED (LB) } & .09 & \text { AVE CONS (MIILB) } & 19.34 \\ \text { FUEL FOR RECHARGE } & .02 & \text { RECHARGE TIME (SEC) } & 374.49\end{array}$

FUEL CELL

BATTERY (OIS)

BATTERY (CHG)

SDURCE

CONTROLLER

MOTOR

DRIVE TRAIN

SOURCE TO WHEEL EFF

AVERAGE
POWER OUT
(HP)
9.25
4.54
2.24

8.32
7.89
6.49
5.85

AVERAGE

CURRENT

68.56

31.95

13.68

86.84

113.46
VELOCITY

MOTOR POWER

FUEL CELL CURRENT

BATTERY DISCHARGE CURRENT

BATTERY CHARGE CURRENT

SOURCE CURRENT

MOTOR RPM

$$
\begin{gathered}
\text { PEAK VALUE } \\
30.00 \\
25.87 \\
284.44 \\
225.64 \\
-18.77 \\
500.00 \\
2800.00
\end{gathered}
$$

.9479

.8220

.9020

.7029

\author{
AVERAGE \\ EFFICIENCY
}

.5331$$
.7029
$$

TIME

134.00

21.00

170.41

20.16

284.00

20.16

31.83

COMPLETED 2 DRIVE CYCLES 


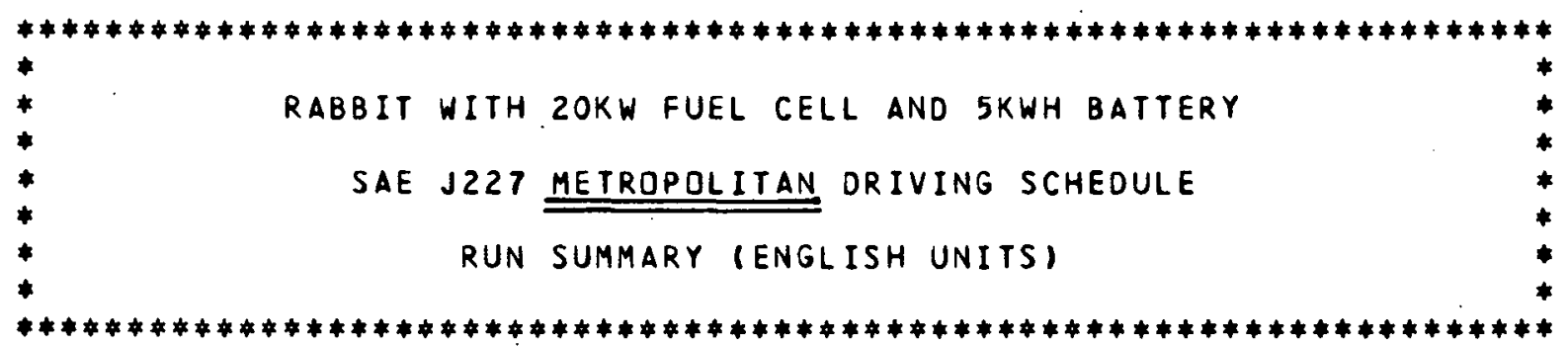

$\begin{array}{lclc}\text { TIME (SEC) } & 300.00 & \text { DISTANCE (MILES) } & 2.08 \\ \text { AVERAGE SPEED (MPH) } & 24.96 & \text { FINAL SPEED } & 0.00 \\ \text { AVE MOTOR RPM } & 1840.22 & \text { AVERAGE THROTTLE } & .4052 \\ & & & \\ \text { INITIAL BATTERY CHARGE } & .8000 & \text { FINAL BATTERY CHARGE } & .7191 \\ \text { MIN BATTERY CHARGE } & .7150 & \text { AT TIME } & 250.00 \\ \text { TOTAL FUEL USED (LB) } & .14 & \text { AVE CONS (MI/LB) } & 14.91 \\ \text { FUEL FOR RECHARGE } & .05 & \text { RECHARGE TIME (SEC) } & 820.77\end{array}$

FUEL CELL

BATTERY (DIS)

BATTERY (CHG)

SOURCE

CONTROLLER

MOTOR

DRIVE TRAIN

SOURCE TO WHEEL EFF
AVERAGE
POWER OUT
(HP)

11.40

4.08

4.51

11.85

11.08

9.02

8.24
AVERAGE

CURRENT

89.49

32.26

14.31

107.44

127.85

.9346

.8141

.9139

.6953

.5109
VELOCITY

MOTOR POWER

FUEL CELL CURRENT

BATTERY DISCHARGE CURRENT

BATTERY CHARGE CURRENT

SOURCE CURRENT

MOTOR RPM

$$
\begin{gathered}
\text { PEAK VALUE } \\
45.00 \\
28.97 \\
286.00 \\
225.64 \\
-21.10 \\
500.00 \\
2852.25
\end{gathered}
$$

AVERAGE EFFICIENCY

TIME

100.00

82.11

170.41

20.16

271.00

20.16

100.00

COMPLETED 2 DRIVE CYCLES. 
THIS PAGE

\section{WAS INTENTIONALLY \\ LEFT BLANK}




\section{APPENDIX C}

THE INFLUENCE OF FUEL CELL/BATTERY POWER SYSTEMS COSTS UN OPERATING COSTS

and attachment:

FUEL CELLS FOR RAILROAD MOTIVE POWER SYSTEMS 
The Baseline Case - The Passenger Automobile

The costs of operation of a typical sub-compact automobile in suburban driving have been estimated to be distributed as follows:

$\begin{array}{llr}\text { 1. Original Vehicle Depreciation } & 20.5 \% \\ \text { 2. Maintenance, Accessories, Parts, } & \\ \text { and Tires. } & 22.3 \% \\ \text { 3. } & \text { Gasoline and Oil (excluding taxes) } \\ \text { 4. Garages/Parking, and Tolls } & 17.3 \% \\ \text { 5. } & \text { Insurance } & 17.3 \% \\ \text { 6. State and Federal Taxes } & 13.4 \% \\ & \text { Total } & \text { approx. } 100.0 \%\end{array}$

Source: Reference $\mathrm{C}-1$.

These figures are for a 1974 vehicle operating on 1974 gasoline prices.

If we consider only a change of operation to an alternative fuel costing, for purposes of illustration, four (4) times the 1974 gasoline price, the overall cost of operation to the owner of the vehicle will increase to about $150 \%$ of the baseline gasoline cost of operation.

If we further propose that. the more expensive fuel form will he used in a fuel cell/battery system costing $\$ 120 / \mathrm{kW}$, and compare this cost to a gasoline fueled internal combustion automobile engine $(\$ 5-\$ 10 / \mathrm{kW})$, the overall cost of operation, to the owner, will increase to a figure in the range of $300 \%$ to $400 \%$ of the baseline gasoline case.

In this situation, the purpose of the vehicle is to provide transportation to the owner. Thus, the result can be summarized by saying that cost of the service will be increased $300 \%$ to $400 \%$ in the hypothetical situation described above. 
It is suggested that this is not the case where the service provided to the user, or customer, is delivered by a system where the service provided by the vehicle and fuel system comprises only a part of the total service system. Specific examples of such systems are truck, bus, rail, and automobile fleet systems.

\section{Intercity Trucking}

The equivalent distribution of costs, generally, for an intercity trucking company are, expressed as a percentage of total operating costs:

1

Depreciation of Equipment

$4.2 \%$

2. Maintenance, Accessories, and Parts

4.5 웅

3. Fuel and oil

$4.7 \%$

4.

Garage/Parking, and Tolls

$0.5 \%$

5. Insurance

2.3

6. State and Federal Taxes

$3.6 \%$

TOTAL

$19.8 \%$

Source: Reference C-2.

Bearing in mind also that a modern diesel engine designed for longterm operation in an intercity truck costs about $\$ 50 / \mathrm{kW}$. compared to the $\$ 5-\$ 10 / \mathrm{kW}$ in the shorter-lived, gasoline fueled passenger car engine, the resulting impact on cost of the trucking service is significantly less than in the passenger car case. The chainge in the above cost component of the total operating costs of the truck line caused by substituting a fuel cell/battery power system and fuel at four (4) times the 1976 reported costs produce about a $20 \%$ increase in total operating costs lassuming $\$ 120 / \mathrm{kW}$ for the fuel cell/battery).

Intracity and Intercity Buses

Both urban and intercity buses in the United States utilize highspeed diesel engines equivalent to those used in intercity trucking. It is anticipated that the same more favorable (than the case with private automobiles) fuel cell/battery power system cost-acceptability situation would also exist. However, no specific inquiry has been made to support this supposition.

Based on a current tractor high-speed diesel engine cost of about $\$ 15,000$ for a $300 \mathrm{~kW}(400 \mathrm{hp})$ rating. 


\section{Rail Systems}

While the budgetary categories used in railroad accounting do not permit an equivalent breakout of costs in the six categories discussed above, they can be estimated to comprise about $15 \%$ of total operating costs (see Reference $(\mathrm{C}-3$ ) compared to $20 \%$ for intercity trucks and 100\% for personal passenger cars, as related above. (See also Reference C-4.)

In the rail case, the cost of a 2000-3000 hp diesel electric primemover system is roughly $\$ 200 / \mathrm{kW}$ at the present time. This price exceeds the $\$ 120 / \mathrm{kW}$ estimate we are using for our fuel cell and battery power system costs.

\section{If we assume that rail service fuel sell/battery power systems} costs the same as current rail diesel engine systems, i.e., $\$ 200 / \mathrm{kW}$ (Reference $\mathrm{C}-5$ ), the impact of fuel costs must still be considered. Novil (Reference $\mathrm{C}-4$ ) has performed a comparative economic assessment of liquid hydrogen fueled rail motive power systems. This assessment examined the conversion of diesel systems to liquid hydrogen powered systems and included the impacts of additional servicing equipment together with a progressive 15-year phaseout of equipment over the useful lifetimes associated with rail motive power units of conventional design. The end result of the conversion produced a tariff increase, the increase in the cost of the rail service, of $3 \%$ to $4 \%$.

Fleet Vericies

While intercity trucks, urban buses, and räil motive power units are, in fact, fleet vehicles, this term is more often associated with fleets of sedans and light trucks in commercial service. The same effect produced by the fact that the costs of vehicle operation are only a portion of the total cost of operation of a service system in the intercity trucking and rail industries holds true for fleets of sedans and liqht trucks in commercial service. However, the percentage of the cost of fleet operations varies widely depending upon the nature of the firm using such vehicles. Two examples are a fleet of vehicles operated by an electric utility company and a fleet of vehicles operated by an organization engaged exclusively in industrial sales representation. 
In the utility case, the effect of increased costs of vehicle opcration on the total cost of electrical service will probably be less than the costs of operation of the vehicles owned by a sales representative firm on the total cost of sales made. However, at this writing, insufficient information is available to the authors to permit developing even a rough estimate of the costs impacts of the use of fuel cell/ battery power systems and alternative fuel forms in these scenarios. Comment

None of the above estimations include the amortization of research, development, and other costs associated with transition to these alternative power and fuel systems. On the other hand, no credit has been taken for the reduction of maintenance and repair costs that might be associated with fuel cell/battery power systems in comparison to internal combustion engines. To provide perspective, maintenance and repair costs are approximately equivalent to equipment depreciation costs in private automobiles and intercity trucking equipment systems. (See tables presented above.) In rail systems, these costs are about 15\% of equipment depreciation costs (Reference $\mathrm{C}-3$ ).

For additional information, a technical discussion of the possible use of fuel cells for railroad motive power systems is attached to this appendix.

It is also appropriate to note that it has been suggested that rail, intercity truck, and vehicle fleet operations, in that order, would be a logical sequence of pursuit toward the goal of eventual conversion of the passenger car to alternative fuel and engine systems.

However, this suggestion was not based upon the previously presented economic impact considerations. Rather, it was stated that this approach is more practical because of such considerations as:

- These systems have fewer fueling points requiring conversion

- A lesser number of vehicle systems are involved

- Single route or fieet conversion is an option

- Regional conversion can be progressively developed

- The risks involved in using equipment and fuels in demonstration operation would be reduced. 
To these advantages must be added the economic advantages developed in the previous pages.

Recommendations

It is recommended that consideration be given to performing an adequately supported investigation of the alternative implementation stratcgies and the life-cycle economics of the use of fuel cell/battery systems in rail, intercity truck, bus, and fleet vehicle applications.

$\underline{\text { References Cited }}$

C-1. Transportation Energy Conservation Dala Book, Transportation Energy Conservation Division ERDA, Rcport No. ORNL-5198, October 1976.

C-2. Foster, R.W., Alternative Fuels and Intërc1ty Truckiny, U.3. Department. of Energy, Report No. HCP/M3294-01, June 1978.

C-3. Status of Railroads of Class I in the U.S., 1967-77, Statistical Summary No. 62, Economics and Finance Department, Association of American Railroads, September 1978.

C-4. Novil, M., A Preliminary Comparative Economic Assessment of the Hydrogen Railroad System Concept, Institute of Gas Technology Project 9515, September 1977 (unpublished).

C-5. Personal communication from R.F. Flinn, Morrison-Knudson, Inc., October 1979. 


\section{Attachment to Appendix $\mathrm{C}$}

FUEL CELLS FOR RAILROAD MOTIVE POWER SYSTEMS

Excerpts from

Cart, E.N., Jr., "Alternative Energy Sources for NonHighway Transportation" ( 3 Volumes), Final Report Under DOE contract No. DE-ACO5-77CS05438, by Exxon Research and Engineering Co., 1979

Part 1 from

Nicholson, E.W., "Possible Applications of Fuel

Cells," (Section 5.1), Volume III-A - Appendices

Part 2 from

Percival, J., and Nicholson, E.W., "Railroads," (Section 7), Volume II - Technical Section

Comment

Exxon Research and Engineering Co., under DOE sponsorship, has recently completed a comprehensive study of alternative fuels for non-highway transportation systems, meaning essentially: rail, air, marine, and pipeline systems.

In this effort, fuel cell power was considered for cach applicatiul aied. In view of the present assessment's observation that the fuel cell/battery power system approach will permit electric propulsion to be able to compete in other areas than those now associated with all-battery electric vehicles, Exxon's views on the potential of the fuel cell as a railroad prime mover are of interest. Pertinent excerpts of their work is appented here : 


\subsection{Character1st1cs of D1esel-Electr1cs}

A diesel-electric locomotive consists basically of a large diesel engine with 16 to 20 cylinders whlch drives a generator to produce directcurrent power. This DC power is distributed to serles-wound DC traction motors at each wheel. In newer models, however, AC generators, or alternators, are belng used in order to overcome the ma1ntenance problems associated with the commutators and brushes required in DC generators. The AC current produced is rectifled by solid-state units to provide the DC power for the traction motors. $(5-21)$

A $3300 \mathrm{HP}$ (at the whoelm) dlamel-olectric locomottve watphe 390,000 pounds, lncluding 4000 gallons of tuel. The englne and allermator for this locomotive welgh 59,500 pounds. Based on an $85 \%$ efficlency from the engine output to the wheels, this represents a welght to power ratio of $15 \mathrm{lb} . / \mathrm{HP}$ or $20 \mathrm{lb} . / \mathrm{kW}$. The corresponding volumetric ratios are about $0.3 \mathrm{cu}$. Et. $/ \mathrm{HP}$ or $0.4 \mathrm{cu}$. $\mathrm{ft} . / \mathrm{kW}$.

\subsection{Posglbilities for Fuel Cells}

It is not inconcelvable that the above ratios could be achleved with fuel cells. As pointed out earlier, the Fuel Cell Powered Vehicle Workshop at Los Alamos in August, 1977 concluded that fuel cells including fuel processing equipment but with no power inversion facilities should be posstble with $30 \mathrm{lb} . / \mathrm{kW}$ and $1 \mathrm{cu}$. ft./kW ratios. $(5-18)$ But, in this case, small units of only about $10 \mathrm{~kW}$ were being considered; the $2900 \mathrm{~kW}$ unfts required for a locomotive of this type should have much better power densities. For example, the power densitles of the $10 \mathrm{MW}$ fuel cell traller in the design study on KOH electrolyte fuel cells Exxon Enterprises did for EPRI(5-9) were $6.3 \mathrm{lb} . / \mathrm{kW}$ and $0.44 \mathrm{cu}$. $\mathrm{ft} . / \mathrm{kW}$. These values do not include the welght and volume required for the fuel processlug section. Further 6 tudy will be needed in order to reach a more definitive conclusion regarding the technical feasibility of substituting fuel cells for the diesel enginealternator-rectifier system in present-day diesel-electric locomotives.

A fuel cell syatem probably cannot be appreclably larger in volume than the present diesel-electric power equipment for the same horsepower rating because the overall dimensions of existing large diesel-electric locomotives are near the limits as constrained by cunnel and bildge elearances, radtus of curvature of tracks, etc. on exlsting railroads. Space within the existing locomotive envelopes lo already well ullitzed by refulrod refulpmant and faclitica. Improved fuel effictency in a fuel cell powered unit could make additional volume avallable for the fuel cell by reducing the size of the fuel tank. 
The allowable welght of a fuel cell system for the required power output needs to be studied further because a number of factors are involved which are associated with the design of the locomotive. One of these factors is "adhesion" between the drive wheels and the rails. Some locomotives are provided with ballast over some of the axles to improve adhesion. It seems possible that, in a modular fuel cell system, some of the fuel cell weight could be distributed to take the place of ballast, thus providing more allowable welght for the fuel cells.

In present locomotive design, the total load-pulling capacity, or tractive effort, is limited by the current-handling capability of the traction motors. More horsepower on board a given locomotive could, however, be used to operate the train at a higher speed. Th1s could have a net economic advantage to the railroad.(5-21) Even though the average daily speed of freight trains is only about $20 \mathrm{miles} / \mathrm{hour}$ (allowing for idle time walting for reassembling of trains, switching, etc.), (5-22) the railroads seem to have little inclination to go to higher horsepower locomotives, as stated earlier.

Another aspect relating to adhesion could prove to be beneficial for fuel cell systems. In a diesel-electric locomotive, when slippage between wheels and track occurs for the limiting axle, power to all the axles must be reduced until the slippage stops. On electric locomotives with power from catenaries, control systems are possible so that power needs to be reduced only to that axle where slippage is occurring. It seems possible that a similar control system could be provided with fuel cells; since the system is modular in nature, separate power takeoffs could be arranged for vartous groupings of modules.

Fuel cells could have a signiflcant advantage in fuel efficiency. The overall fuel efficlency of a diesel-electric when operating on productive load over an average load cycle is about $37 \%$.(5-21) But, diesel engines are most susceptible to damage, and thus increased maintenance costs and downtime, when they are being started up, as temperatures equalize; during this time, coolant and lubricant flows must be carefuliy monitored. In addition, the coolant is subject to freezing in cold weather. For these reasons, diesel-electric locomotives are generally kept running at idle continuously when they are not in load service, or in the shop for service. Road engines generally operate at tille 45-55\% of the time, and switch engines $77 \%$. For the road engines, the fuel consumed during idling amounts to about $6 \%$ of the total consumption, and reduces the overall fuel efficiency to about $33 \%$. It is possible, however, that diesel efficiencles could be increased in the future through incorporation of bottoming cycles.

Fuel cell systems have been demonstrated to be easily and quickly started up and shut down, so continuing to run them at i.dle would not be necessary.* Assuming a $40 \%$ fuel efficiency can be obtained with a phosphoric

* The fuel reforming section would probably be maintained at temperature except for ldling perlods of greater than about 4 hours. 
acid fuel cell system, and naphtha can be used as fuel, as shown in Table 5-1, this would reduce the fuel requirement on board the $3300 \mathrm{HP}$ locomotive being considered from 4000 gallons to 3670 gallons, or a saving about 5400 pounds of weight and $45 \mathrm{cu}$. ft. of volume on board the locomotive, as well as reducing the operating costs for fuel.

Of course, the critical question is whether or not a fuel cell system could be economically competitive with diesel-electrics in railroad service. This is discussed in another section. It appears worthwhile to consider both the phosphoric acid fuel cell system for the 1978-85 period, and the molten carbonate system for later application. It is also conceivable that a $\mathrm{KOH}$ electrolyte system could be utilized if a feasible means can be devised to remove $\mathrm{CO}_{2}$ from the fuel and air streams to the fuel cell.

(fart 2)

\subsubsection{Fuel Cei13}

A separate appendix (7-II) has been devoted to a full discussion of fuel cells and their application to railroads. Below, is a condensation of the main points.

Fuel cells, while costly are no more so than several of the other engines considered in this study. Their efficiency is the highest, maintenance is reasonable, and they can be switched off to save fuel which other engines waste when idling. Finally, they may be capable of being electrically coupled to the wheel motors in a way that would save part of the losses which today's locomotives suffer in the al ternator or direct current generators ( $v i z$. , the $5 \%$ loss on freight engines and the $8 \%$ loss on switching locos).

A phosphoric actd cell looks as though it could break even with a diesel engtne at a fuel cost of $\$ \overline{5} / M \bar{B} t u$. Similarly a molten carlumite cell would break even al a fuel cost of $\$ 4 / \mathrm{MB}$.tu.

The weight of the fuel cells is somewhat higher per horsepower than that of an equivalent diesel engine, but this would not necessarily incur any disadvantage.

$\begin{array}{lcc}\begin{array}{l}\text { Mass of Engine } \\ \text { Plus Fuel, Lbs }\end{array} & \begin{array}{c}\% \text { of Mass of } \\ \text { Total Locomotive }\end{array} \\ \begin{array}{l}\text { plus al ternator rec- } \\ \text { tifier and fuel }\end{array} & 71,000 & 24 \\ \text { phosphate fuel cell } & 88,000 & 30 \\ \text { plus vol tage regulator } & & \\ \text { plus fuel }\end{array}$


A detailed design and engineering study is needed to determine the feasibility of using fuel cells on locomotives. Three important questions which have to be answered are:

1. Can the weight and volume requirement be accommodated? The volume of a phosphate cell system and its fuel is about $2600 \mathrm{ft}^{3}$, compared with $1600 \mathrm{ft}^{3}$. for a diese $1 /$

electric engine and its fuel. The weights and volumes of molten carbonate cells are not known at present.

2. Would the cells be adversely affected in performance by vibration, shocks, and tilting?

3. In the case of carbonate cells, operating at $1200^{\circ} \mathrm{F}$, what problems of safety are there to be overcome? 
THIS PAGE

\section{WAS INTENTIONALLY LEFT BLANK}




\section{APPENDIX D}

\section{RECENT DEVELOPMENTS IN}

CRYOGENIC HYDROGEN CONTAINER TECHNOLOGY

FOR VEHICLES 
In the vehicle simulation section presented previously in this assessment report, on-board hydrogen storage systems were analyzed on the basis of weight of hydrogen contained expressed as a percentage of loarled container weight (i.e. container + fuel). The figures used were selected to provide representation of three classes of cases:

\section{Case 1 1\% of loaded weight representative of iron-titanium hydride storage and low alloy steel pressure vessels \\ Case $25 \%$ of loaded weight. representative of magnesium-titanium hydride storage or very advanced, composite structure pressure vessels. \\ Case $322 \%$ of loaded weight representative of cryogenic liquid hydrngen storage vessels.}

While adequate literature is available descriptive of the first two system storage cases, such is not the case with the third case. Developments in this field have occurred with significant reductions to practice having been achieved only recently (Ref. D-l).

Fig. D-1 and D-2 illustrate cryogenic hydrogen storage tank systems that have been used to fuel internal combustion engines in vehicle applications. Additional tanks have been constructed and demonstrated in service (Ret. i-1). however, these tanks (Fig. D-1 and D-2) are representative of conversions of tanks originally designed for service with other cyrogens dud wlıivlı liäve becn modified for hydrogen service.

An example of a cryogenic hydrogen delivery system designed specifically for application to vehicle fueling is the DFVLR system illustrated in Fig. D-3. This tank has the following general specifications:

$\begin{array}{ll}\text { Liquid Volume Capacity } & \text { lbU liters ( } 39 \text { ydliuns) } \\ \text { Tank Mass, Empty } & 43 \mathrm{kilograms} \\ \text { Liquid Mas̈, Full. } & 11 \text { kilograms } \\ \text { Operating Pressure, (max) } & 8 \mathrm{bar} \\ \text { Heat Leakage } & 2.0 \mathrm{watts} \\ \text { Hydrogen Boiloff Rate } & 5 \mathrm{liters} / \mathrm{day} \\ \text { Pressure Buildup Rate } & 0.4 \mathrm{bar} / \mathrm{hr} \\ \text { Design Acceleration } & 30 \mathrm{~g}\end{array}$


A unique aspect of the DFVLR Tank System is the fact that an automated fueling system capable of supporting the use of the tank in vehicle applications has also been constructed by the DFVLR (Fig. D-4) .

This system is contained in a single cabinet and is designed to load a cold tank in approximately five (5) minutes. The sequence of operation of this refueling, or "service station", includes verification of pressure, by vacuum, integrity of the connections made to the vehicle tank, filling valves sequencing, phase flow sensing, manual valve actuation checking, fill and vent line pump-out, and fueling cycle completion and "clear for disconnect" signalling.

The operation of this tankage and "service station" system is presently under investigation by the Los Alamos Scientific Laboratory under U.S. Department of Energy Contract W-7405-Eng-36. The project will involve the operation of an intermediate size Buick "Century" 4-door sedan with the DFVLR Tank and automatic fueling system (Reference D-2).

$\underline{\text { Costs }}$

In addition to the technical problems implicit in the design of such fuel handling systems, there is a obvious cost impact on the total vehicle costs. Only one study has been accomplished to date (Ref. D-1) directed at estimating what the range of costs of such tanks would be. The general findings are briefly summarized in tables $\mathrm{D}-1$ to $\mathrm{D}-3$. Due to the relative immaturity of this technology, these estimates should be used with caution.

\section{REFERENCES}

D-1 Escher, W.J.D., Survey of Liquid Hydrogen Container Technology for Highway Vehicle Fuel System Applications, U.S. Department of Energy, Report No. HCP/M2752-01, November 1978

D-2 Stewart, W.F., "Liquid Hydrogen-Fueled Vehicle Project," Los Alamos Scientific Laboratory presentation at the DOE Automotive Technology Development Contractor's Coordination Meeting, 23-25 October 1979, Dearborn, Michigan. 

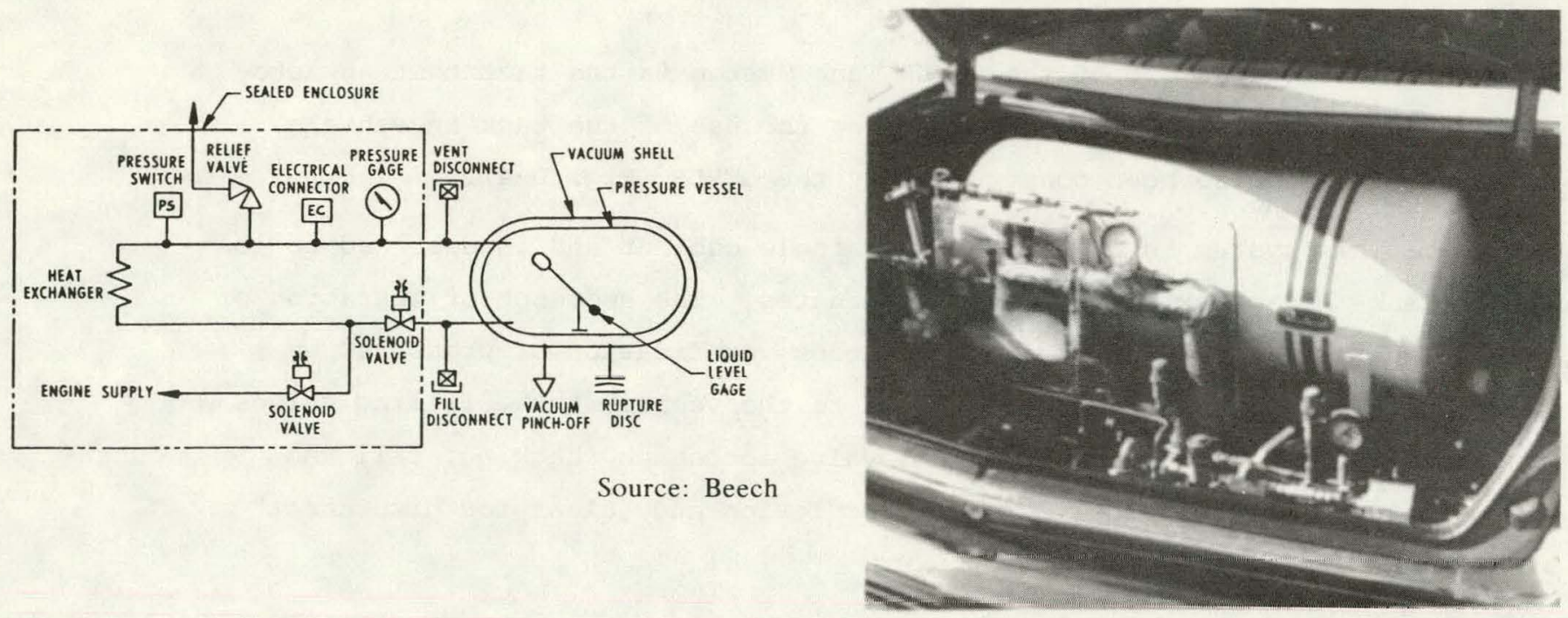

Figure D-1. Beech LNG Container Functional System Schematic Diagram
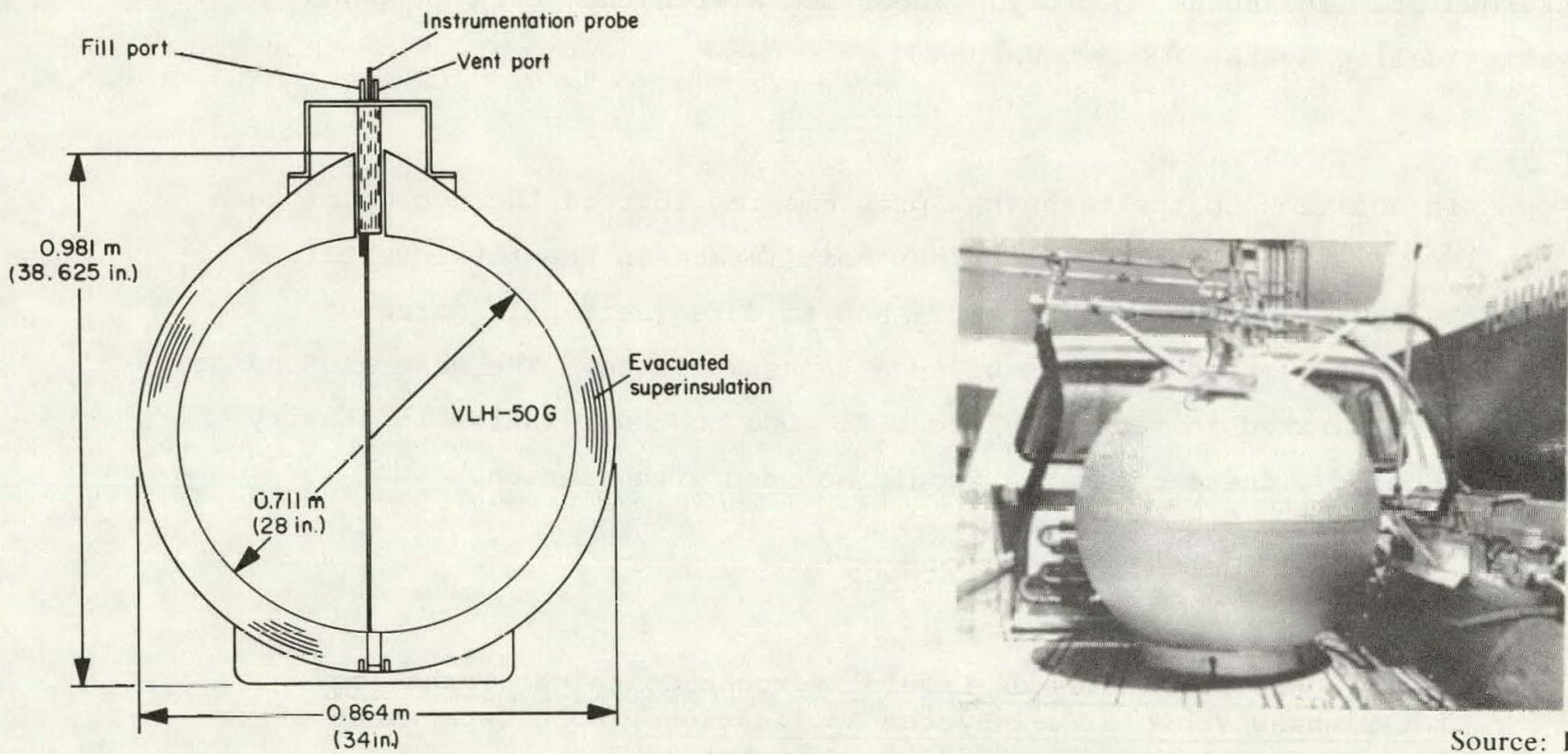

Source: LASL

Loss rate $-1 \%$ ver day

Capacity - $0.19 \mathrm{~m}^{3}$ ( 50 gallons) $\mathrm{LH}_{2}$

Maximum working pressitre - $207 \mathrm{kPa}(30$ usic)

Empty weight - $42.6 \mathrm{~kg}$ (94 lb) (no top)

Top section - $2.72 \mathrm{~kg}(6 \mathrm{lb})$

Source: LASL

Source: Ref. D-1

Figure D-2. MVE Cryogenics VLH-150 Liquid Hydrogen Container Cross-Sectional View 

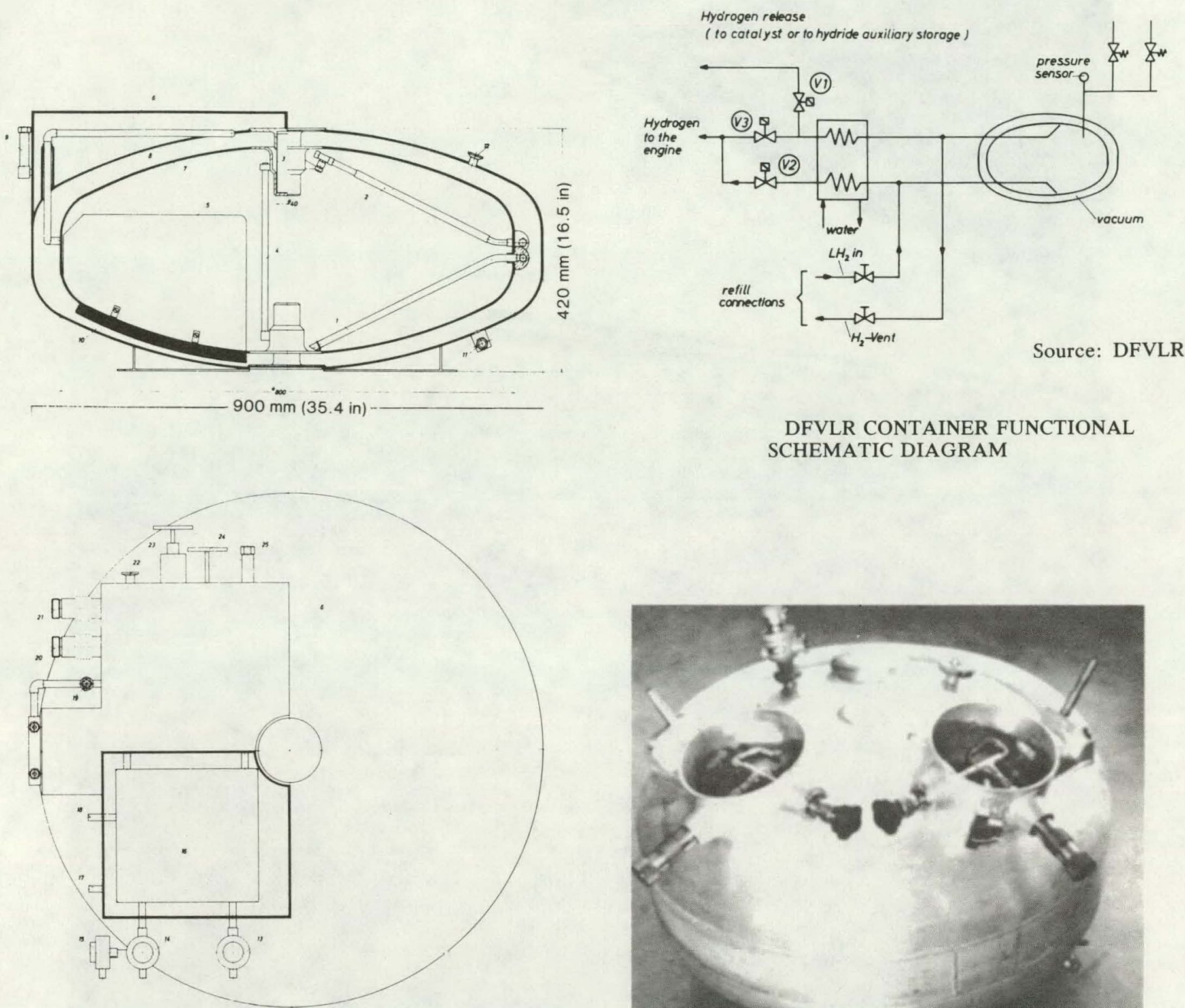

Source: DFVLR

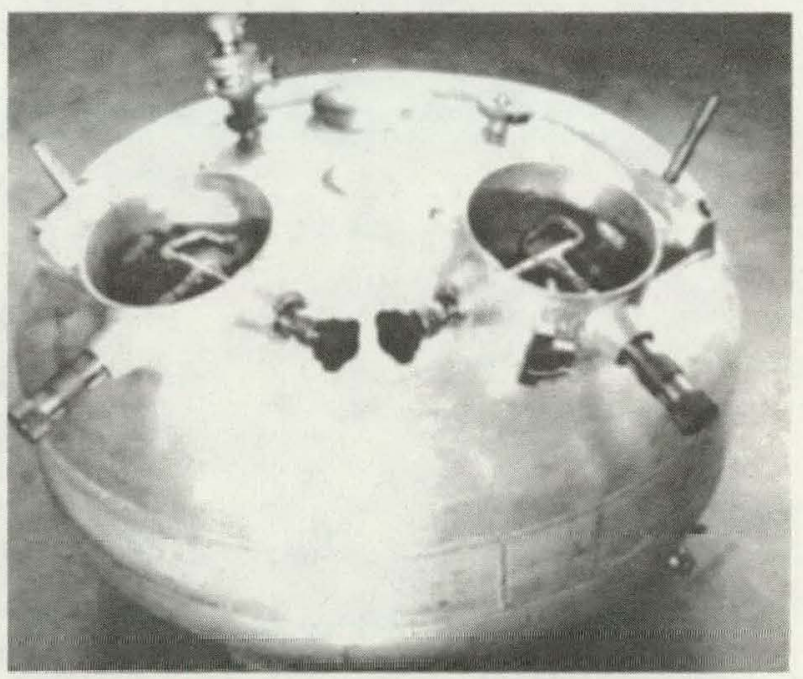

Source: DFVLR

DFVLR LIQUID HYDROGEN CONTAINER (TANK I) PLAN AND CROSS-SECTIONAL VIEW DRAWINGS

DFVLR CONTAINER FUNCTIONAL SCHEMATIC DIAGRAM 


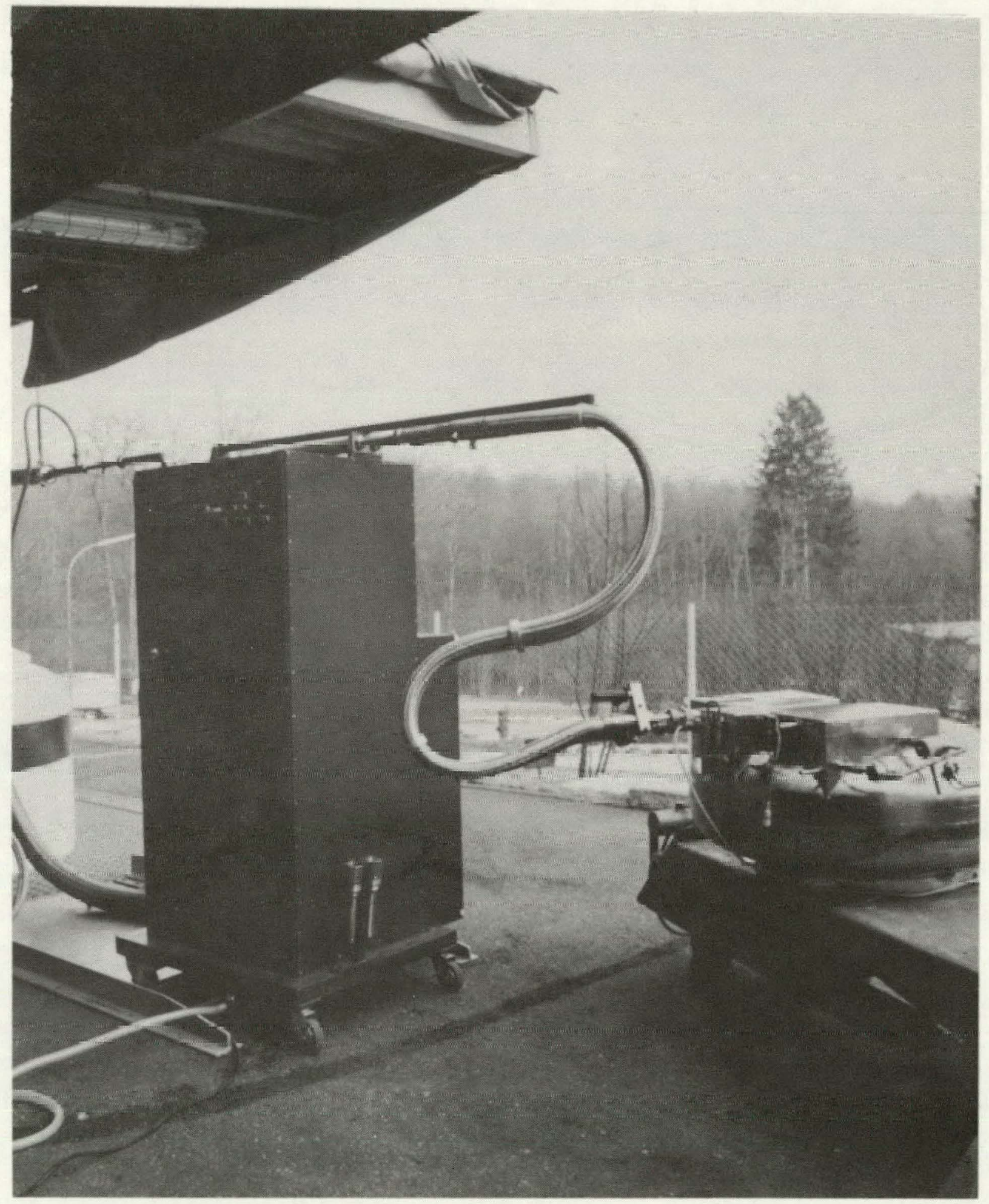

Figure D-4. DFVLR Automated Fueling System. Dewar Supply Tank is on the Left, the Fueling System is in the Center and the DFVLR 32 Gallon Tank is on the Right. Tankage and Fueling System Have Been Operated in the F.R.G. in an Automotive Vehicle System. System is Presently at Los Alamos. 


\section{TABLE D-1 BASIC TANK SPECIFICATIONS}

(1) Liquid Hydrogen capacity--50 gallons (189 liters)

(2) Nominal operating pressure, maximum - 50 psig (3.4 bar. $345 \mathrm{kPa}$ )

(3) Some provision for active pressurization, e.g. resistance heater

(4) No-loss pressure lock-up time, minimum--3 days

(5) Configuration (geometry, orientation) horizontal cylinder

(6) Provision for liquid level gaging (type of system optional)

(7) Fill and vent connections--standard type, adequate to meet any applicable governing regulations, existing or anticipated

(8) Reasonably robust construction for normal, safe over-the-road highway service.

\section{TABLE D-2}

\section{MANUFAC'TURERS' FSIIMATES FOR PRODUCTION COSTS OF VEIIICI.E IIQUII) HYIDROGEN CONIAINERS}

(OEM price basis, 30,000 units, 1978 dollars')

$\begin{array}{lr}\text { Estimate A } & \$ 1.640)^{2} \\ \text { Estimate B } & 1.590^{3} \\ \text { Estimate C } & 950 \\ \text { Average } & \$ 1.393\end{array}$

Notes: 'Adjusted by an escalation factor of 1.06 , applied to 1977 estimates.

"Extrapolated slighily from estinates for two smaller sized containers: "bare tank" equivalent estimate: $\$ 1.430$.

Interpolated for 30,000 unit basis from three estimates between 1,000 and 100,000 units (see below).

\section{TABLE D-3}

\section{A MANUFACTURER'S ESIIMATES FOR PRODUCTION COSTS OF VEHICLE IIQUID IIYDROGEN CONTAINERS}

(OEM price basis, 1,000-100,000 units, 1978 dollars') Production-lot
Assumed

1,000

10.000

100.000 Manufacturer's
Estimate

$\$ 2.330$

1,840

1.430

Notes: 'Adjusted by an escalation factor of 1.06 applied to 1977 estimates.

${ }^{2}$ Corresponds to "Estimate $B "$ in previous table.

${ }^{3}$ Derived by applying the manufacturer's estimales (lliis table) 16 the average estimate from the previous lable.
Adjusted Estimate

$\$ 2.040$

1,610

1.250
Source: Ref. D-1 